Portland State University

PDXScholar

$10-8-2021$

\title{
The Discourse/Pragmatic Functions of Japanese Okkē
}

Peter Fodor

Portland State University

Follow this and additional works at: https://pdxscholar.library.pdx.edu/open_access_etds

Part of the Asian Studies Commons, and the Discourse and Text Linguistics Commons Let us know how access to this document benefits you.

\section{Recommended Citation}

Fodor, Peter, "The Discourse/Pragmatic Functions of Japanese Okkē" (2021). Dissertations and Theses. Paper 5868.

https://doi.org/10.15760/etd.7739

This Thesis is brought to you for free and open access. It has been accepted for inclusion in Dissertations and Theses by an authorized administrator of PDXScholar. Please contact us if we can make this document more accessible: pdxscholar@pdx.edu. 
The Discourse/Pragmatic Functions of Japanese Okkē

by

\title{
Peter Fodor
}

A thesis submitted in partial fulfillment of the requirements for the degree of

\author{
Master of Arts \\ in \\ Japanese
}

Thesis Committee:

Suwako Watanabe, Chair

John Hellermann

Karen Curtin

\section{Portland State University 2021}




\begin{abstract}
Okay is one of the most commonly used words in the English language. It is also one of the most commonly borrowed English-origin loanwords across all of the world's languages. Although there is a wealth of research on the communicative functions of English okay, there is comparatively little research on the many borrowings of the word in various other languages. In order to address this gap in the literature, this study explores the differences in discourse/pragmatic function between the English word okay, and the Japanese borrowing of the word, okke.
\end{abstract}

Extensive research in discourse analysis, pragmatics, and conversation analysis shows that English speakers use okay to accomplish a variety of discourse/pragmatic functions. The functions of okay established in the relevant literature are: (1) A marker of transition. (2) A structural marker in monologic speech. (3) A marker of irony or sarcasm. (4) A tag question. (5) A method of seeking or giving permission. (6) An assessment. (7) A response token.

In order to determine which of the functions listed above can be accomplished by Japanese speakers when they use $o k k \bar{e}$, this study analyses audio and video data of Japanese native speakers playing an augmented reality game. Evidence from the analysed data shows that Japanese okkē is used by Japanese speakers to accomplish the following functions: (1) A marker of transition. (2) A marker of irony or sarcasm. (3) An assessment. (4) A response token.

Additionally, it was found that the way in which Japanese speakers utilize okkē as a marker of transition is different in some cases from how English speakers utilize okay 
as a marker of transition. In group settings among Japanese speakers, the group members sometimes each repeat $o k k \bar{e}$ tokens one person after another in order to indicate group consensus of readiness to transition. Other noteworthy differences found between okay and $o k k \bar{e}$ are that (1) Okke tends to appear as the only word within a turn more often than okay. (2) Okkē is used as a response token only to a completed utterance, while okay can be used as a response token to either a complete or incomplete utterance. (3) Unlike okay, $o k k \bar{e}$ is sometimes used outside of any ongoing talk to mark physical action transitions such as walking to stopping. 


\section{Acknowledgments}

I would like to sincerely thank all of the thesis committee members for their support over the years: Dr. Suwako Watanabe for all of the help and advice she gave me while I wrote this thesis, Dr. John Hellermann for mentoring me in linguistics research and giving me so many opportunities to learn, and Dr. Karen Curtin for teaching me how to teach. I could not have completed this thesis without their help.

I also owe a debt of gratitude to all of the PSU faculty who have taught me so much during my time as both an undergraduate and graduate student: Dr. Jon Holt, Dr. Laurence Kominz, Dr. Steven Thorne, Dr. Kimberley Brown, Janet Cowal, Dr. Kathleen Godfrey, Dr. Kenneth Ruoff, and all of the other wonderful educators who have helped broaden my horizons. I am also very thankful to Takako Yamaguchi at PCC for introducing me to Japanese studies and encouraging me to go above and beyond.

I would also like to thank all of my colleagues at PSU who helped me along the way. Although not a complete list everyone I'd like to thank, the following names come to mind: Adam Okoye, Natsuko Llewellyn, Jitsuya Nishiyama, Andre Shepherd, Kumiko Takizawa, Vanessa Howe, Narumi Iwasaki, Teppei Fukuda, Elsiemae Ito, and Yuya Sano.

Finally, I would like to thank the people outside of my academic life for all of their cooperation while I went to graduate school: My parents for their relentless encouragement and support of my education, Alice for helping so much with the transcripts and supporting me though thick and thin, Mike for teaching me electrical discharge machining, and my tabletop roleplaying friends for all the fun times. 


\title{
TABLE OF CONTENTS
}

\author{
Abstract.....i \\ Acknowledgments.....iii \\ List of Tables.....vi \\ List of Figures.....vii
}

Chapter 1: Introduction.

1

1.1. A Brief Introduction to English Okay and Japanese Okkē.....1

1.2. Organization of this Thesis.....5

Chapter 2: The Discourse/Pragmatic Functions of Okay.

7

2.1. Transitional Okay.....7

2.2. Monologic Okay.....15

2.3. Ironic/Sarcastic Okay.....21

2.4. Tag Question Okay.....23

2.5. Permission Okay.....27

2.6. Assessment Okay.....29

2.7. Response Token Okay.....32

2.8 Summary of the Functions of Okay....34

Chapter 3: Research Methods

3.1. Research Questions.....37

3.2. Data and Participants.....38

3.3. Methods.....43

Chapter 4:The Discourse/Pragmatic Functions of Okkē. .45

4.1. Functions Not Found to be Applicable to Okkē .....45

4.2. Transitional Okkē.....46

4.3. Ironic/Sarcastic Okkē.....55

4.4. Assessment Okkē.....61

4.5. Response Token Okkē.....67

4.6. Okkē Cascades: A Function Unique to Okkē.....69

Chapter 5: Conclusion. .82

References.....90 
Appendix A: English and Japanese AR Game Texts.....98

Appendix B: Transcription Notation.....101

Appendix C: Transcripts of the AR Game.....104 


\section{List of Tables}

Table 2.1: The Discourse/Pragmatic Functions of Okay.....38

Table 3.1: Group Member Pseudonyms .....43

Table 5.1: The Discourse/Pragmatic Functions of Okkē.....88 


\section{List of Figures}

Figure 1: Pitch curve and articulation of $o k k \bar{e}$ spoken by $\mathrm{M}$ on line 2 of excerpt (27)....61

Figure 2: Pitch curve and articulation of $o k k \bar{e}$ spoken by $\mathrm{M}$ on line 8 of excerpt (27).....62 


\section{Chapter 1}

\section{Introduction}

The goal of this thesis is to discover the ways in which the English-origin word okay has been adapted for use in modern spoken Japanese as the loanword okke, particularly in the discourse/pragmatic sense. The current chapter will provide an overview of general historical and linguistic information about English okay, how it came to be used as a loanword in the Japanese language, and why research on this topic is warranted. Finally, the overall organization of this work will be discussed at the end of this chapter.

\subsection{A Brief Introduction to English Okay and Japanese Okkē}

Okay originated in 1830s Boston among journalists as an initialism for Oll Korrect, which is a play on words for All Correct (Read, 1963a). Playful use of language such as this was the trend at the time, and the newly coined word quickly spread across the country via literary circles and newspapers. Contrary to popular belief, okay is an American English invention, and does not originate from another language (Cassidy 1981).

At first glance, okay may seem like a rather simple word due to its ubiquity and frequency. After all, it is the 137th most commonly used word in spoken English; just one rank below no, and tied with only (Leech, Rayson \& Wilson, 2001). Likewise, it is often taken for granted that okay is simply a synonym for yes, fine, satisfactory, good, or acceptable. This is how dictionaries such as Oxford and Merriam-Webster tend to define 
the word. However, taking a closer look at okay will reveal a surprising level of complexity.

Syntactically, okay is actually one of the most versatile words in the English language. A simple set of constructed sentences reveals that okay can be used grammatically as an insert, or any type of lexical word as classified by Biber, Conrad, \& Leech (2002).

(1) Adverb: He understood the content of the manuscript okay.

(2) Predicative Adjective: The manuscript is okay.

(3) Modifier Adjective: It's an okay manuscript.

(4) Verb: Can you please okay the manuscript?

(5) Noun: She gave me the okay to publish the manuscript.

(6) Insert: Okay, let's edit the manuscript.

Although its syntactic variability is an interesting novelty, this thesis will focus on the discourse/pragmatic functions of okay and its Japanese counterpart okke. The examples above are useful for illustrating what I mean by discourse/pragmatic function. Examples (1) - (5) are pragmatic in function. That is to say, the speaker is using okay to perform a social action such as assessment or giving permission. Example (6), however, shows an instance of okay being used as a discourse marker. A discourse marker is a nonobligatory utterance-initial word that brackets a unit of talk in order to provide cohesion and connection between various levels of discourse while sometimes setting the tone and 
providing information about the upcoming utterance (Schiffrin, 2001). In example (6), for example, okay is indicating that a transition in activity or topic has occurred. I use the term discourse/pragmatic function because okay is capable of both discourse and pragmatic functions as described above, and both categories are examined in this thesis. Taking this into consideration, okay is functionally very versatile. Depending on how functions are categorized and distinguished from each other, some studies have identified as many as 10 different discourse/pragmatic functions that okay is capable of (Gravano et al., 2012).

The global dominance of American and British culture in the decades following its invention led to okay being spread to nearly every major language across the world as a loanword. Although, at the time of this writing, no dedicated research exists detailing how many languages have taken in okay as a loanword, Metcalf (2010) lists Dutch, German, Swedish, Polish, Finnish, Italian, Spanish, Welsh, Hebrew, and Korean among many others as having some English-origin loanword equivalent of okay.

As it spread across the world, okay inevitably reached Japan as well. There are no authoritative sources outlining exactly when the word entered the Japanese language, but we can speculate based on the history of western loanwords entering Japan. Historically, there were three major influxes of western loanwords into Japan, occurring in the Edo period (1603 - 1868), the Meiji and Taisho eras (1868 - 1926), and the post-World War 2 occupation of Japan by the American forces (1945 - 1952) (Frellesvig, 2011). It is unlikely that okay entered the Japanese language before the end of World War 2. This is because the vast majority of loanwords that entered the Japanese language during the Edo 
period came from Dutch and Portuguese due to Japan's very limited contact with other languages and cultures during this time period. Also, because the history of okay only overlaps with the Edo period by around 30 years, it's highly unlikely that the word would have made its way from English to Dutch/Portuguese and into Japanese within this span of time. After the Edo period ended and the Meiji era began, there was a large influx of loanwords from various western languages including English. However, it is unlikely that the colloquialism okay was one of these words because the vast majority of the words that entered Japanese during the Meiji and Taisho eras were literary, technical, scientific, or otherwise scholarly in nature (Kay, 1995). Okkē is most likely to be a product of the post-World War 2 American occupation of Japan from 1945 - 1952. During this time period, there was frequent spoken contact between Americans and Japanese, and the English language education materials mandated by the occupation forces were based on conversational American English (Gottlieb, 2005). Additionally, the first instance of $o k k \bar{e}$ being used in the Japanese written language, as recorded in loanword dictionaries, came in 1951 with Hayashi Fumiko's novel Meshi (Arakawa, 1967). This places the likely inception of $o k k \bar{e}$ between 1945 and 1951.

Semantically, okke is often described as being equivalent to shōchi(suru) (agreement/acceptance) or yoroshii (good/fine), and also described as a form of shōnin (consent/acknowledgement/approval) by most Japanese dictionaries, making it roughly equivalent to English okay in meaning. However, like the majority of other westernorigin loanwords in Japanese, okke is strictly a nominal or nominal fragment as described by Jorden and Noda's system of syntactic classification (1987). Okkē, like most other 
loanword nominals, has the potential to be used as a certain type of nominal called a $n a$ nominal, which gives it the ability to modify other nominals similar to how an modifier adjective would modify nouns in English. This means that, at least syntactically, it is much less versatile than its English counterpart okay.

The apparent lack of syntactic versatility of $o k k \bar{e}$ raises the question - is $o k k \bar{e}$ also limited in a discourse/pragmatic sense? Because there is currently no research on the topic, it is not known what kind of social actions Japanese speakers make with $o k k \bar{e}$, and how Japanese speakers use $o k k \bar{e}$ to structure their talk. This is in stark contrast to the immense volume of research on English okay, which describes in detail how English speakers act and organize with okay during their everyday talk.

It is known from research by Alim (2004) on okay usage in communities that speak Black American English that it is possible for okay take on new

discourse/pragmatic functions when adopted by specific speech communities. Alim found that okay was sometimes used as a marker of feminine solidarity in the communities that he researched. A similar phenomenon could possibly be the case for the Japanese borrowing of the word as well.

\subsection{Organization of this Thesis}

Throughout the following chapters, this thesis will attempt to answer the question of whether the functionality of okay has changed as a result of it becoming okke. . For the sake of clarity, it should be noted that English okay will oftentimes be referred to as simply okay, and Japanese $o k k \bar{e}$ will oftentimes simply be referred to as okkē. 
Chapter 2 presents a literature review of existing research on the discourse/pragmatic functions of English okay in order to establish a basis for comparison of Japanese $o k k \bar{e}$. Chapter 3 defines the methodologies, data, and research questions used in this thesis to compare English okay with Japanese okkē. Chapter 4 examines the discourse/pragmatic functions of Japanese $o k k \bar{e}$ via an original analysis of task-oriented talk by Japanese native speakers. Finally, chapter 5 summarizes the findings of this thesis and proposes further avenues of research into Japanese $o k k \bar{e}$. 


\section{Chapter 2}

\section{The Discourse/Pragmatic Functions of Okay}

The following section will attempt to provide a taxonomy of the discourse/pragmatic functions of English okay by reviewing the relevant literature on the subject. By reviewing the literature and establishing a taxonomy of the functions of okay, I will establish a basis for comparison when I uncover the functions of Japanese $o k k \bar{e}$. Although not all of the studies covered in this chapter focus mainly on okay, a variety of studies that are relevant to this thesis are included.

It is important to note that any single okay token can hold a multitude of discourse/pragmatic functions simultaneously. Being transitional, for example, does not preclude an okay token from being an assessment or response token at the same time. Therefore, although the excerpts in this thesis may be illustrative of a single function for any given section, an astute analyst might be able to glean other functions from the same okay token.

\subsection{Transitional Okay}

One of the most common discourse/pragmatic functions of okay is to mark transition points in action, topic, discourse context, or interaction in general. Functionally, transitional okay can be both discourse and pragmatic oriented; that is to say, a speaker can use okay as a social action to deliberately bring about a transition, or it can be used to mark a transition in discourse that is already underway. The following sections will summarize the literature on transitional okay in various contexts. 
Many of the earliest scholarly findings on okay come from studies on telephone conversations in the field of conversation analysis. These studies focus on various aspects of the social organization of telephone conversations, and often mention okay usage in passing, not as the main focus of the research. Among these studies is Schegloff and Sacks (1973), which is the first study to provide a detailed description of the structure of telephone conversation closings. Within Schegloff and Sacks' research, okay is often found to play a critical role in the sequences that lead up the final parting exchange of a telephone call. Excerpt (1) is illustrative of this phenomenon.

(1) (Schegloff and Sacks 1973: 314)

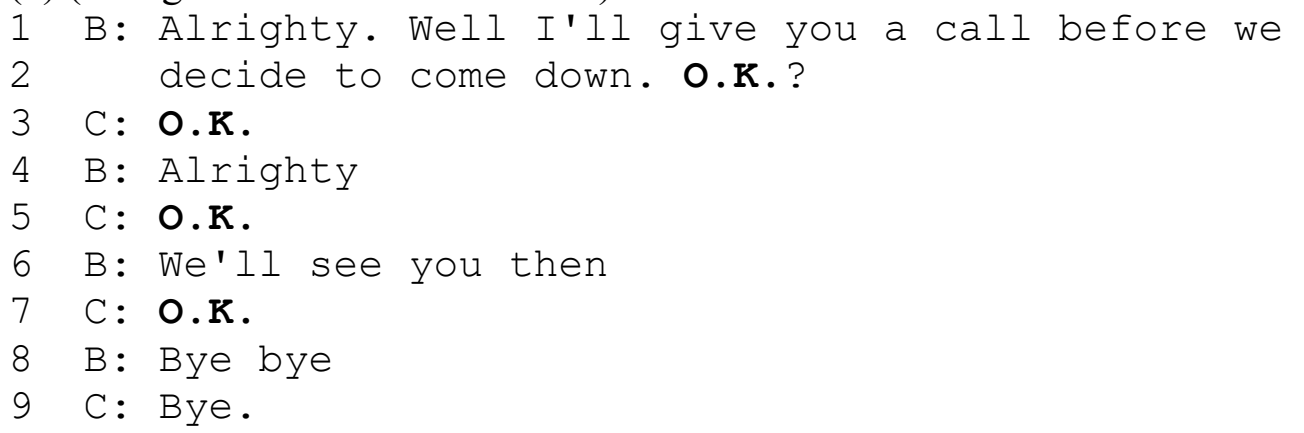

According to Schegloff and Sacks, the series of okay tokens between lines 1 and 7 are part of a pre-closing, which eventually leads up to the terminal exchange on line 8 and 9 . Okay has the following function in pre-closings: speakers work their way toward the closing of a conversation or topic by saying okay and thus intentionally passing up the opportunity to take the floor or produce talk relevant to the topic at hand. This lack of relevant talk leads to the mutual agreement that the conversation can be transitioned to a close. 
Button (1987) builds on Schegloff and Sacks' findings by observing that the closing sequences of telephone conversations such as those in (1) are frequently suspended, and other avenues of talk are pursued before resumption of the closing. In effect, okay provides a means of either transitioning out of the conversation or alternatively transitioning into a divergent topic that usually encompasses unfinished business between the conversants. Button finds that repetitive okay exchanges are frequently used as a mechanism to allow speakers the opportunity to move out of the closing sequence and back into the conversation if necessary. In example (1) above, for example, it's conceivable that one of the speakers might remember a yet unspoken detail during the production of repetitive okay tokens between lines 1 and 7, and interject with this detail before the terminal exchange on lines 8 and 9 .

Schegloff (1986) further finds that okay is often used by speakers in telephone conversations when transitioning out of initial greetings and into a main topic of conversation. The environments in which these okay usages occur are coined by Schegloff as 'howareyou' sequences because they involve one party asking the other how they are doing. According to Schegloff, when asked how one is doing during a telephone conversation opening, a neutral response such as okay indicates that no further elaboration is needed, and other topics of talk can be pursued. Thus, leading to an expedited transition from the conversational opening to another topic of conversation. Excerpt (2) illustrates how a neutral response such as okay can immediately lead to a change in topic (in this case, teaching). 
(2) (Schegloff 1986: 135)

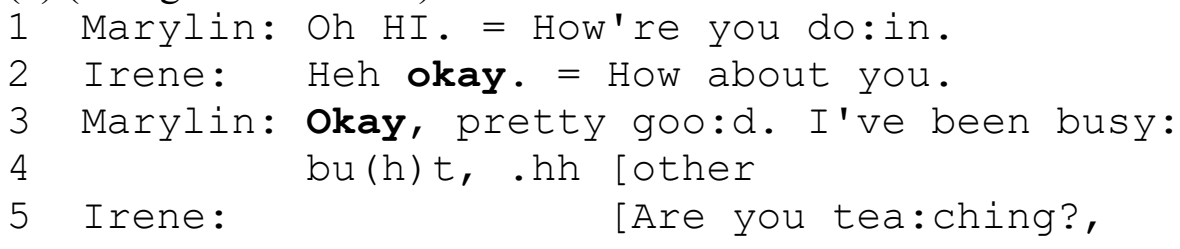

Also focusing mainly on telephone conversations, Beach (1993) is the first study to explicitly identify the transitional nature of okay while acknowledging its multifunctionality. In his study, Beach shows that okay is often simultaneously used as a response token that acknowledges the current state of the conversation, while also acting as a pivot point for upcoming topics and actions. An example of the multifunctionality of transitional okay can be seen in (2), where okay is acting as both an assessment and a point of topical transition.

Far from being limited only to telephone conversations, research on transitional okay in face-to-face interaction is also plentiful. Research in this field begins with Merritt (1978), who examines the role of okay in casual service encounters. In her study, Merritt finds that when a speaker requests an action of somebody else (such as a store clerk), the transition from a verbal segment to action is frequently marked by an okay token produced by the person who is obligated to perform the action. Excerpt (3) is illustrative of how okay appears at the boundaries of verbal and non-verbal action.

(3) snack truck (Merritt 1978: 8)

1 C: Do you have Marlboros?

2 S: Yeah, Hard 'or soft pack?

3 C: Soft please.

4 S: o.k. ((turns to get)) 
On line 4, the boundary between talk and embodied action is delimited by an okay token produced by S, the doer of the action. Thus, Merritt concludes that okay plays an important role in bridging verbal and non-verbal action. Merritt also observes that okay can be used to release someone else from an ongoing action. A clerk may, for example, tell a customer that they can't find the item requested by the customer, and the subsequent okay uttered by the customer delimits the search for the item, effectively letting the clerk 'off the hook'.

Kovarsky (1989) makes a similar observation in his study on okay usage in speech-therapy clinical environments. Quite often in Kovarsky's data, therapists would tell patients to do something, but the patients would fail at the task or be unresponsive. In these cases, the therapists would almost invariably release the patient from the requested action with an okay, as shown in excerpt (4) where the speech therapist tries to elicit the word sink from a child patient.

(4) (Kovarsky, 1989: 140)

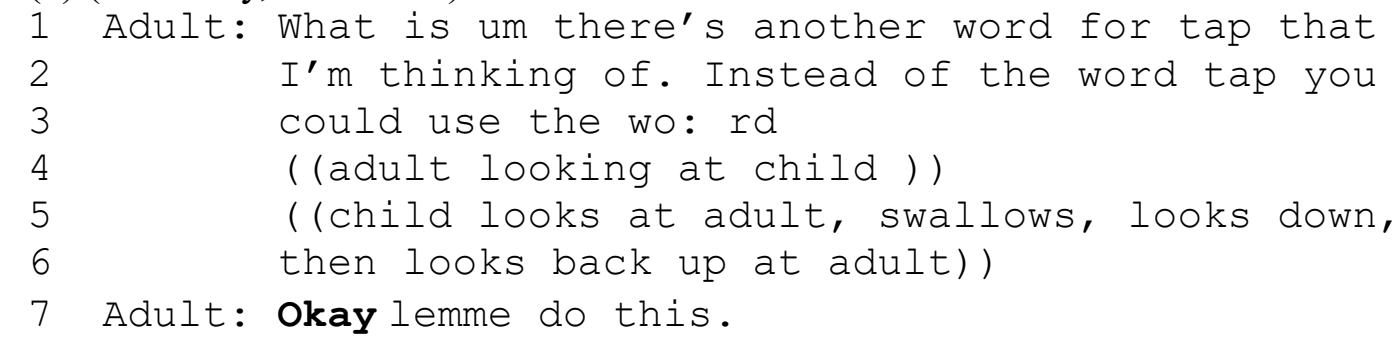

After the child fails to produce the desired word by line 6, the adult terminates the activity with an okay on line 7, releasing the patient from the requested task, and initiates an alternative approach to the problem. 
In addition to marking points of transition between verbal and physical action, Beach (1995) shows that okay also frequently marks boundaries between topics. This is especially prevalent in institutional talk where one party controls a routine flow of the talk. Beach analyses patient/physician interactions in particular, describing the way in which medical professionals structure topical change via repeated okay usage. Excerpt (5) shows one such instance where a physician $(\mathrm{S})$ is asking a patient $(\mathrm{PJ})$ various questions about their habits and lifestyle, and uses okay to acknowledge the patient's answer while simultaneously shifting to the next topic.

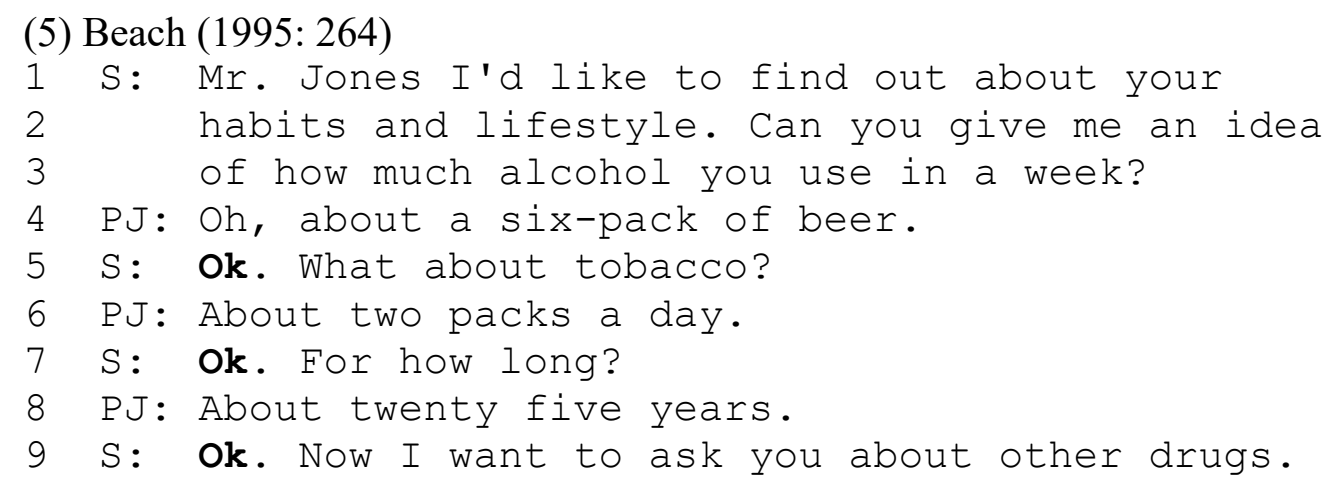

One important element of transitional okay at play in excerpt (5) is that of routinization. The physician is going through the routine of asking standard questions about patient lifestyle, and is using okay as a means of 'checking off' finished phases of the routine. In this sense, Condon (2001) argues that okay is used to mark discourse that is progressing along its default/routine trajectory, similar to what is seen in excerpt (5). Within these default discourse routines, participants use tokens such as okay to verify each others' understanding of their progress in the predetermined routine as it continues. 
As such, okay usage in many settings has become routinized to the point where it can accomplish many standard unmarked interactional tasks by itself, allowing for routine interactions to succeed despite limited lexical diversity. Excerpt (6) is a good example of this: it shows an interaction where a family is going through the routine of planning a vacation to Hawaii, marked by heavy okay usage.

(6) (Condon 2001: 498)

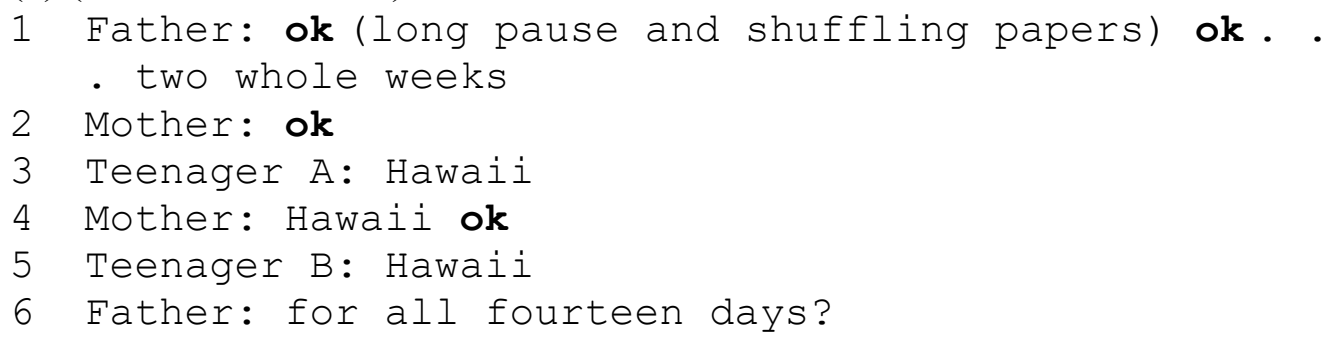

Condon hypothesizes that in situations such as (6), okay usage would decline if somebody involved in the routine went 'off the rails' and disrupted the routine. In order to test this hypothesis, Condon conducts an experiment that examines discourse marker usage in a set of 16 face-to-face and 16 computer mediated task-based interactions. In her study, Condon determines which kind of environments okay, well, and so tokens appear in by categorizing the discourse function of the utterance that follows the token, and placing it into one of 17 categories such as suggestions, requests for information and disagreements. Additionally, Condon measures the mean utterance length (MLU) of turns following okay and well tokens. Her findings indicate that occurrences of okay in unmarked routine environments such as suggestions are more frequent than in marked non-routine environments such as disagreements. Likewise, utterances following okay 
tokens tend to be shorter than those following well tokens, which often precede disagreements. These two findings hold true for both the face-to-face and computer mediated datasets that Condon examined. Thus, Condon concludes that okay plays an integral part in routine sequences due to its unmarked nature and tendency to precede shorter utterances.

Seemingly contrary to its usage in facilitating routines, okay has also been shown to function as a means of breaking away from the ongoing discourse. In his analysis of transitional okay, Beach $(1993 ; 1995)$ observes that okay is sometimes strategically used to force a shift of topic. Beach notes that speakers in institutional settings can, for instance, purposely deploy multiple repeated okay tokens as a way of closing down or ignoring the talk of others; thereby, forcing topic/activity change. Following a similar line of research, Turner (1999) in Gardner (2001) shows that this strategic use of transitional okay is not limited to institutional settings - repeated purposeful deployment of okay tokens can happen when a speaker in any conversation is uncomfortable due to a problematic topic and wishes to change the course of talk. Similarly, Gaines (2011) describes cases of okay in heated arguments and conflicts where strongly articulated okay tokens can mean something akin to stop or we're done. Excerpt (7) shows a case of okay being used to aggressively terminate an uncomfortable topic.

(7) SDCL: G/S:16 (Beach 1991: 54-55)

1 S: OKA : : :YAlright (.) OKAYI'll GO n- le(t)'s just

2 drop it for t'night okay? (.) I don't wanta talk 3 about it anymore. 
In cases such as (7), okay takes on a primarily pragmatic role by actively signalling to others that a certain line of talk needs to end.

In summary, transitional okay has been shown in the literature to facilitate opening and closing telephone conversations, mark shifts between verbal and physical action, mark shifts in topic/action, mark progress in routine or default discourse trajectory, and forcefully close down undesired topics of talk. These can potentially be reduced to 3 sub-categories because topic change, opening/closing telephone conversations, and default trajectories can all be broadly considered to be shifts in topic/action. Therefore, transitional okay primarily serves the functions of (1) marking shifts in topic/action, (2) marking shifts between verbal and physical action, and (3) shutting down undesired topics of talk when used forcefully.

\subsection{Monologic Okay}

Similar to transitional okay, monologic okay also often tends to mark discourse boundaries in speech. However, unlike transitional okay, monologic okay is not used in interactional contexts where two or more speakers are exchanging talk. Instead, it appears in contexts where a single person is talking (usually to a group) without the expectation of response from the listener(s). Alternatively, monologic okay can also potentially apply to private or semi-private speech where the speaker is talking to themselves.

The first dedicated study on monologic okay is by Levin and Grey (1983). This particular study by Levin and Grey is short, and acts more as a pilot study to identify the phenomenon and call for more detailed research on the subject. In their study, Levin and 
Grey observe that public speakers in academic environments frequently use okay at discourse boundaries. This leads Levin and Grey to coin the term lecturer's okay as a reference to the context in which they observed this usage of okay. The lecturer's okay has prosodic and gestural features distinguishing it from other usages of okay: there is usually an unfilled pause before or after the okay, it is uttered at half voice, and the speaker often breaks eye contact with the audience. Levin and Grey conclude their study by suggesting that the lecturer's okay is often not meant for the audience, but rather that it is a form of semi-private speech acknowledging to oneself that a task or topic has been completed. This is similar in function to the routine/discourse trajectory transitional usage of okay that Condon (2001) identifies in interactional contexts, suggesting that monologic okay might be inherently transitional in nature.

The most comprehensive research on monologic okay to date is a study by Schleef (2008), which is meant to address loose ends left by Levin and Grey (1983). Schleef asserts that the lecturer's okay should be considered within the sociocultural context within which it appears. Therefore, factors such as age, gender, discourse task, and academic subject are taken into consideration within this study. Schleef also considers the distribution of three other discourse markers used interchangeably with okay: now, alright, right. According to Schleef, a taxonomy of monologic okay and other discourse markers used in lectures can be defined by considering previous research by Heisler (1996), Bangerter and Clark (2003), Rendle-Short (1999), and Levin and Grey (1983). Schleef's proposed taxonomy consists of five distinct subcategories of discourse 
marker usage. The following section describes these subcategories in the context of okay, followed by an example of each.

1, Monologic okay can occur as a textual marker; these cases of okay indicate a simple shift in discourse or topic without necessarily indicating any relationship between the previous and forthcoming discourse. These cases usually include a short pause before the textual marker.

(8) (Levin \& Grey, 1983: 196)

I copied that for you because it shows the influence of self-concept for both the subordinate and the superior on the communication process. [Pause.] OK. First of all, one of the problems going through the research literature is that actually no studies...

2, Monologic okay can also occur as a pre-closing, in which case the topic or discourse does not shift immediately, but rather leads towards an inevitable closing, much like a pre-closing okay would in a conversational context.

(9) (Simpson et al., 2000: LEL280JG051)

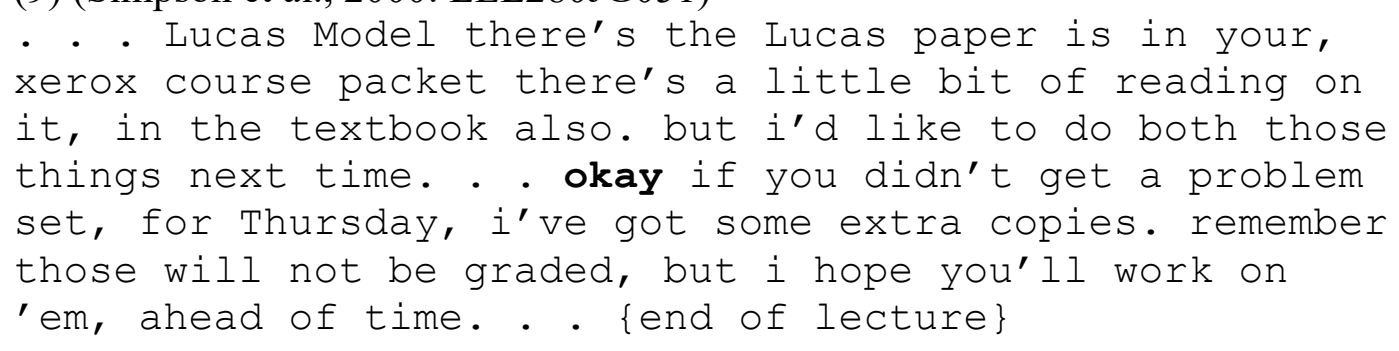


3, Attention-getter okay generally occurs at the beginning of a lecture and simultaneously serves to initiate a new discourse while signalling to the audience that their attention is needed.

(10) (Simpson et al., 2000: LEL175SU098)

okay a few announcements. . . a few announcements. before we begin i get a lot of email questions and you can keep telling me lots of questions about, project number three.

4, In some cases, monologic okay can occur as an elaboration marker, where the speaker draws attention to an established point in the lecture by inserting an okay before an elaboration of a continuing topic.

(11) (Simpson et al., 2000: LEL200JU105) you are to assume, that when you see a group of nonmetals clumped together, that they are an ion, themselves and the nonmetals are bonded together, okay, and they exist as one unit. you can, figure out the charge of something like $\mathrm{N}$-O-three by simply going again to the Periodic Table. .

5, Finally, monologic okay can occur as a hesitation token when the speaker is attempting to reorient themselves or resolve some kind of problem.

(12) (Simpson et al., 2000: LEL175MU014) you know, the exams may be hard and i may do some unusual things in the class but in the end, um $i$ do realize that we have to give reasonable sets of grades. 


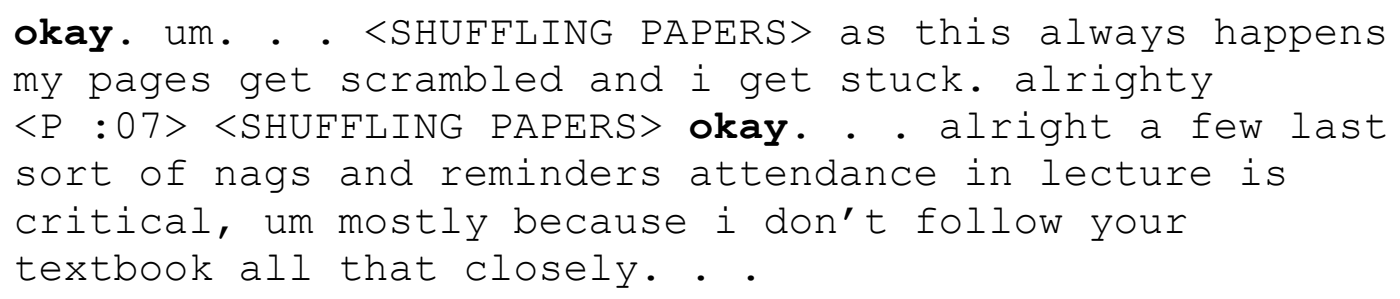

In addition to his proposed taxonomy of discourse marker usage in lectures, Schleef (2008) conducts a quantitative analysis by attempting to pinpoint who actually uses which discourse markers under what circumstances. In his analysis, Schleef counts how many okay, alright, now, and right tokens are produced by 24 university faculty members in 24 different lectures. The faculty members are separated into categories of age, sex, and academic discipline. The results of Schleef's analysis indicate that differences in academic discipline are statistically significant: okay occurs more frequently in science lectures than humanities lectures. Schleef postulates that this is because lecturers in the sciences often rely on visual demonstrations such as formulae, code, and experiments to convey concepts to students. Therefore, science lecturers tend to shift activity and discourse structure more frequently and more drastically than humanities lecturers, frequently employing okay at these juncture points. For example, a chemistry lecturer may need to step away from the podium to mix two chemicals together in order to demonstrate a reaction. In a case such as this, there is a good chance that both stepping away from the podium and returning to it would be marked with an okay. The results also indicate that there is a clear preference for use of the structural marker okay over the structural marker now among younger lecturers. Older lecturers tend to use now more often than okay to structure their talks. Right tokens were found to be extremely 
infrequent in all contexts compared to other discourse markers. Finally, gender is not a statistically significant factor in monologic okay usage according to Schleef's findings.

Othman (2010) conducts an analysis similar to Schleef (2008) by counting discourse marker usage in a corpus of 12 lectures conducted by 3 different lecturers. Her findings confirm Schleef's taxonomy of 5 different usage patterns of monologic okay and other discourse markers used in lectures. Additionally, Othman finds that okay tokens produced by lecturers can occasionally have interactive properties as well. Sometimes the lecturer will use okay or another discourse marker with a rising intonation as a response elicitor when seeking to check if students have questions or are ready to proceed to the next task or topic. Excerpt (13) shows an example of a response elicitor usage of okay.

(13) (Othman, 2010: 673)

So you've done it, now, then I'll take it in the end. (b) Just one per company, I don't need two per company, okay? <L1 looks at students>

In this case, it's conceivable the students who didn't understand would speak up and ask questions. Othman postulates that cases of okay with a rising intonation used by lecturers are potentially interactive and may elicit responses from students, while cases with falling intonation are truly monologic lecturer's okay tokens as originally described by Levin and Grey. Additionally, by interviewing the lecturers featured in her data and showing them the transcripts, Othman shows that speakers are not necessarily conscious of what they mean to communicate with their okay usage during lectures. 
In summary, okay tokens produced in monologic environments have been found to have 6 different sub-functions in organizing talk: (1) Textual markers, which indicate a shift in discourse or topic. (2) Pre-closings, which indicate that the speaker is getting ready to finish. (3) Attention-getters, which are often used at the start of lectures or presentations to elicit the attention of the audience. (4) Elaboration markers, which highlight or emphasize a point that the speaker is making. (5) Hesitation tokens, which are often produced while the speaker is having difficulties, and attempting to reorient or re-organize themselves. (6) Response elicitors, which are semi-interactive tokens used to elicit a response from the audience, especially when the speaker is checking audience understanding or readiness to progress to the next task or topic.

If considered outside of interactional context, monologic okay can potentially be included under the umbrella of transitional okay. The 6 sub-functions of monologic okay described above can potentially be reduced to 2 of the 3 sub-functions of transitional okay that I posit in section 2.1. All of the sub-functions of monologic okay either mark shifts between actions and topics, or between speech and physical action. Therefore, monologic okay can be interpreted as transitional okay that occurs in a certain context.

\subsection{Ironic/Sarcastic Okay}

The existence of an ironic/sarcastic function of okay in English is generally acknowledged by scholars who study the word. However, there has yet to be any dedicated research on this topic. Various studies on okay and other response tokens make brief mention of this function, but fall short of doing a detailed analysis. Beach (1993), 
for example, describes a derisive variation of okay that speakers use as a means of showing contempt or feigning surprise/deference in response to an extreme or offensive statement or action. Excerpt (14) shows a discussion about capital punishment where G (an opponent of capital punishment) perceives the stance presented by S (a proponent of capital punishment) as extreme/reprehensible, and produces an ironic/sarcastic okay token in response.

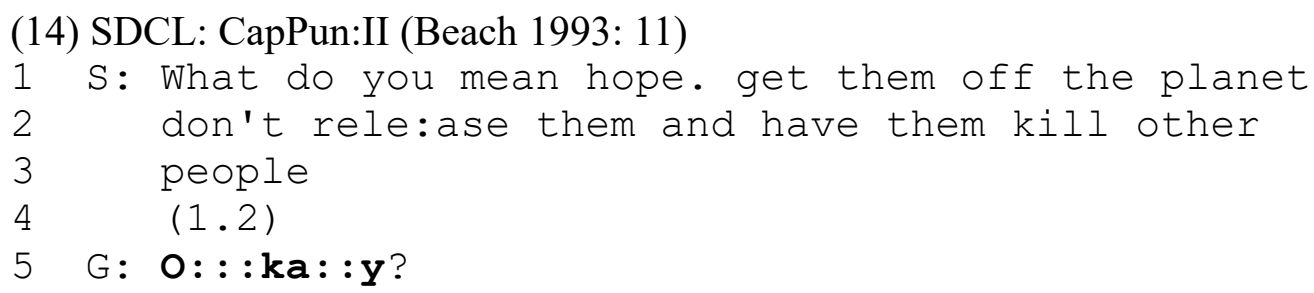

As mentioned previously, this particular usage of okay is generally used in response to a statement or action with the intent of expressing sarcasm or irony. This property is not unique to okay, and other response tokens such as right and yeah can potentially be imbued with the same ironic/sarcastic tone. Following the preference for minimization of turn size proposed by Schegloff (1982), these ironic/sarcastic response tokens can be seen as a way for speakers to expedite a series of expressions into a single compact turn. Therefore, a single sarcastic/ironic okay token can simultaneously do the work of acknowledging the previous statement or action while expressing an entire statement such as "I think what you just did or said was foolish".

The defining feature of ironic/sarcastic okay is its marked prosody and intonation. In excerpt (14), take note of (1) the pause on line 4 after the offending statement and 
before the okay token, (2) the elongated articulation of the okay token shown on line 5, and (3) the rising intonation at the end of the okay token. As seen in the above example, ironic/sarcastic response tokens are often expressed through a combination of three articulatory and prosodic features: dramatic pauses, elongated articulation, and an unusual rising or falling intonation. According to Clift (1999), speakers commonly express a sarcastic/ironic tone by using dramatically timed and articulated utterances that are clearly out of place in the sequence, and contrast with the established footing. In the example above, the long pause before the okay token can be interpreted as dramatically timed and its rising intonation can be seen as purposefully out of place. Similarly, according to Rockwell (2007), sarcasm in conversation is often perceived when an utterance contains notably lengthened vowels, as is also featured in the example above. It is also plausible that negative connotations other than irony and sarcasm can be conveyed by speakers when they use other kinds of marked prosody and articulation.

\subsection{Tag Question Okay}

A tag question is a syntactic operator that is composed of a statement followed by an interrogative. Common examples of tag questions in English might include "It's cold, isn't it?" and "You're Frank, aren't you?". Okay has been known to appear within tag questions in the position of the interrogative. A tag question itself is not a discourse/pragmatic function, but okay tokens that appear as tag questions tend to have discourse/pragmatic functions that are uniquely associated with the tag question position. Tag question okay tokens can have several functions that are unique to this environment. 
The most intuitive of the possible functions of tag question okay is that of the confirmation check. In a study on the functional differences between okay, alright, and right, Filipi and Wales (2003) identify a usage of okay that is regularly employed by instruction givers after they finish an explanation. Filipi and Wales' data consist of interactions between a person giving instructions about how to reach a location on a map to another person. Excerpt (15) shows an instance from the aforementioned data where the instruction giver checks the understanding of the recipient with a confirmation check okay token.

(15) (Filipi and Wales 2003: 443)

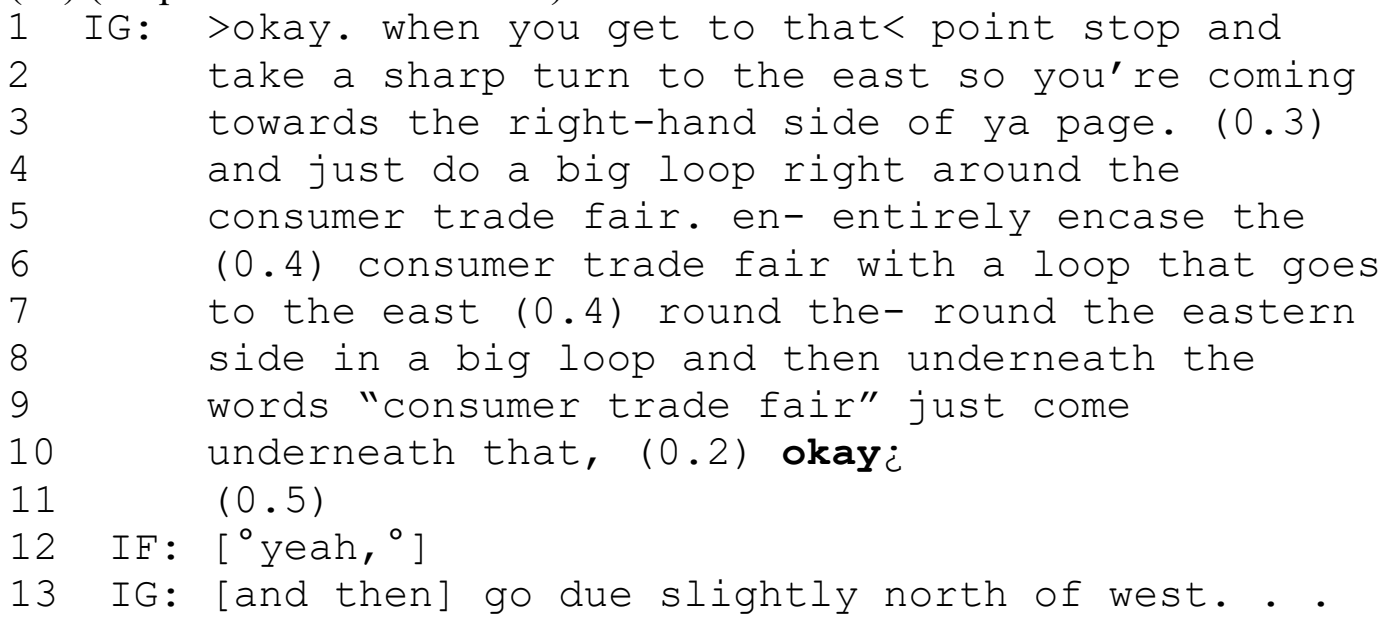

Excerpt (15) shows IG initiating a long instruction-giving sequence with a transitional okay token on line 1, then stopping with a confirmation check okay token on line 10. The confirmation check then elicits an affirmative response from IF on line 12, which signals to the instruction-giver that the instructions so far have been understood 
and they can continue giving instructions. The short 0.2 second pause before the confirmation check okay token is typical of this function.

Tag question okay can also potentially function as a politeness strategy. Heisler (1996) refers to this usage of okay as command softener okay, while Gaines (2011) refers to it as insistive okay. Heisler's data and analysis are based on English translations of Montreal French, which makes it difficult to draw any conclusions about English okay from his research. Therefore, Gaines' interpretation of insistive okay will be discussed here. In Gaines' research he analyses a spoken corpus that consists of a police officer confronting a suspected offender after a sting operation in order to further uncover the multifunctionality of okay. Excerpt (16) shows an instance of the police officer (DK) using okay to soften his command.

(16) (Gaines 2011: 3306)

1 DK: So what I'm tellin' you is I don't wanna be lied

2 to [right now ]

3 LC: [Okay. ]

4 DK: Okay? So (.) we'll start over. Yer gonna get

5 outta here yer gonna hafta (.) pay a fine and

6 that'll be it. o[kay?]

7 LC: [Fine]

According to Gaines, the police officer's (DK) primary goal in this situation is to elicit a confession from the suspect (LC). This is accomplished by questioning the suspect, and having the suspect produce an account of events that corroborates with the police officer's account of events. Getting the suspect to produce this account of events requires a certain level of cooperation, so it is in DK's best interest to soften his 
commands. To accomplish this, DK strategically alters his command into question form by adding an okay token with rising intonation after the command on line 6 . According to Gaines, this has the effect of appealing to solidarity. With the command turned into a request/appeal to solidarity, the imposition placed upon LC is reduced and a more equal power relationship is fostered, reducing the perceived threat of the police officer. In cases such as this, question-tag okay functions less as an actual question, and more as a politeness strategy. This, however, is not unique to okay; according to Holmes (1982), tag questions in general can be used as an appeal to solidarity.

Gaines (2011) additionally proposes that tag question okay can occur as an appeal to solidarity without any command taking place. These cases often occur when a speaker is reassuring a listener who is in an uncomfortable situation, as excerpt (17) from the same police interview shows.

(17) (Gaines 2011: 3297)

1 DK: Ahright==I- I know I c'n bring ya ta jail but

2 that's not my goa: : I here okay?

3 LC: Well please don't do that You- you-=

4 DK: I'm not gonna bring ya ta jail okay?

LC (the suspect) is obviously frightened of going to jail. Therefore, in order to pacify LC, DC deploys tag question okay on line 2 to reassure him and downplay the risk of jail. He uses this strategy again on line 4 in combination with explicit assurance that LC is not going to jail. 
In summary, tag question okay has three sub-functions: (1) a confirmation check, (2) a command softener, and (3) an appeal to solidarity. Heisler's (1996) study on Montreal French speakers proposes further functions for tag question okay, and many of these are intuitively reasonable functions for English, but I choose not to include these here because evidence for these functions in English has yet to be uncovered.

\subsection{Permission Okay}

Okay is commonly used as a method of both seeking and giving consent or permission. For example, a person seeking to enter someone another person's home might ask the homeowner a question such as "Is it okay if I come in?", and the homeowner might respond affirmatively simply with "Okay". At this point, there are currently no studies dedicated to analysing permission okay in naturalistic environments, although permission okay appears within several papers analysing permission in general. Speer \& Stokoe's (2012) study on permission structures, for example, acknowledges that okay is used for seeking/giving permission, but does not analyse okay usage itself in any detail.

Maynard, Freese, \& Schaeffer's (2010) study about interactional phenomena surrounding requests for participation in surveys makes the observation that acceptance responses such as oh yeah, yeah, sure, oh sure, no problem, alright, and okay are conversationally preferred in the sense that they are produced quickly and without interactional difficulty. On the other hand, permission-seeking okay tokens tend to be delayed in comparison. An extreme case of this can be seen in Speer and Stokoe's (2012) 
data, wherein a respondent (C) gives permission with an okay token before the caller (CT) can even finish his original request.

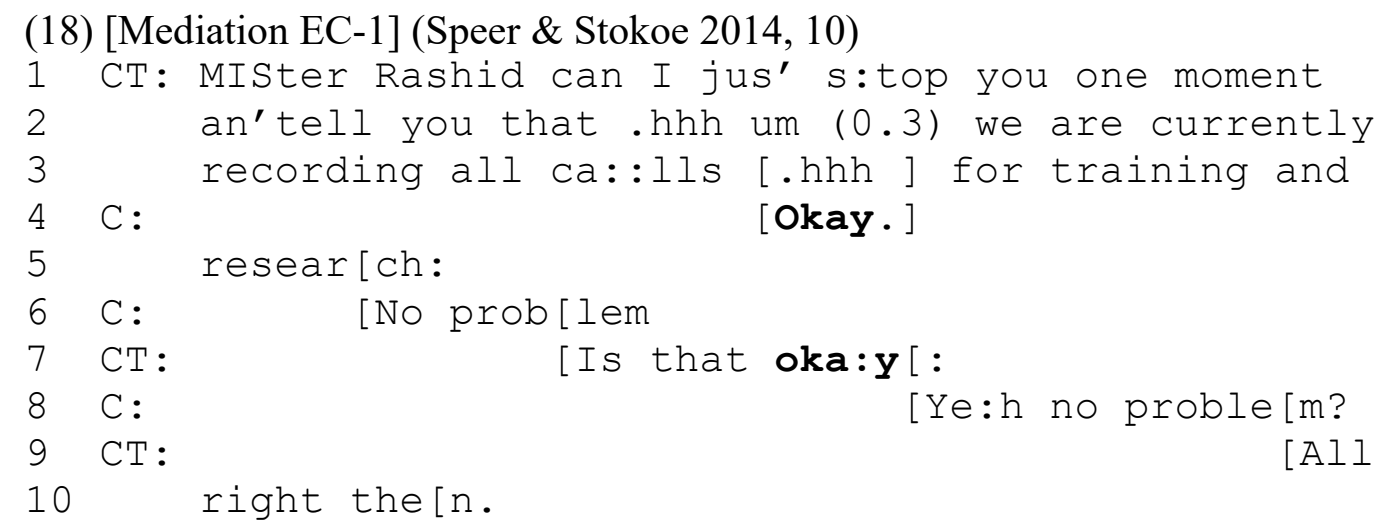

In excerpt (18), C can be seen giving consent in line 4 with an okay token before CT can even deploy the permission-seeking okay in line 7. This seemingly unusual ordering happens for two reasons: First, the permission-giving okay came quickly because it is a form of agreement, and agreement is a preferred action, which means that it tends to be deployed quickly and without hesitation. Second, the permission-seeking okay came late because permission seeking is a dispreferred action, which means that it is fraught with interactional difficulties such as pauses, hesitation noises, and explanations (as seen on lines 2-3).

Van Zyl and Hakenom (2013) also examine okay in permission sequences and find marked prosodic characteristics in cases of reluctant acceptance. In an experiment designed to uncover how reluctance is prosodically encoded into okay tokens, van Zyl and Hakenom elicit permission from eight participants who are instructed to only respond with okay. Half of these tokens are elicited under conditions that are in conflict with a 
schedule that is presented to the participants. Van Zyl and Hakenom find that when participants are presented with a scheduling conflict, they tend to express reluctance via increased duration of their okay tokens.

\subsection{Assessment Okay}

One of the most widely recognized uses of okay is that of an adjective used to assess quality. However, this is not as straightforward as it seems; the degree of quality expressed by okay seems to be somewhat inconsistent - depending on the case, something that is called okay might actually be good, or it might not be very good. This raises the question: what degree of quality can an okay assessment potentially represent? PilletShore (2003) addresses this question by examining the metrics of okay in a corpus of parent/teacher assessments of student performance, which is an environment where an okay assessment can potentially represent a wide range of differing levels of quality. Pillet-Shore's analysis indicates that an assessment okay token can represent a variety of differing qualities depending on the intonation/prosody of the okay token and the interactional environment in which it is deployed.

The first type of assessment okay described by Pillet-Shore is the standalone binary okay/not okay metric; specifically, okay is delivered without other surrounding assessments or context. In these cases, when something is assessed as okay, it tends to be perceived as meaning good enough, lacking problems, and not requiring intervention. This form of simple assessment okay can also be used as a method of refusal when used 
to describe one's own state, indicating that one is 'fine as is', and 'not in need of any goods or assistance'. Excerpt (19) shows a typical case of okay being used to refuse food.

(19) (Mirrivel \& Tracy 2005, 23)

1 Joe: ohr:: (.) don't those look good (.)

2 Tom: no: : : (.) I'm okay (.)

In line 1 , Joe attempts to entice Tom into eating some muffins, but is subsequently rebuffed by Tom's declaration in line 2 that he is okay. When something is okay in this sense, the okay tends to double as a transitional okay and calls an end to the current topic or activity as seen in excerpt (19). In contrast, when something is not okay, it is perceived that 'there are problems and intervention or elaboration of some sort may be necessary'. Regardless, in these cases, the okay is taken at face-value and actually considered fine. Schegloff's (1986) 'howareyou' sequences described in section 2.1 are a further example of an okay usage that has both assessment and transitional properties.

Different from the standalone binary okay/not okay pair described above, PilletShore also describes cases where okay can actually be perceived as not fine via its interaction with other surrounding assessments. In these cases, okay is being compared to some other upgraded assessment such as good or doing well in close proximity, and as a result okay takes on a relatively downgraded status in comparison. In the same vein, it's also possible for an okay to be upgraded when it appears in close proximity to a downgraded assessment such as no good or awful. As such, participants often negotiate the relative status of okay through the deployment of various other assessments in 
proximity to okay. In excerpt (20), which is from a parent/teacher discussion about student performance, an okay assessment is being used by the teacher in contrast to a doing well assessment.

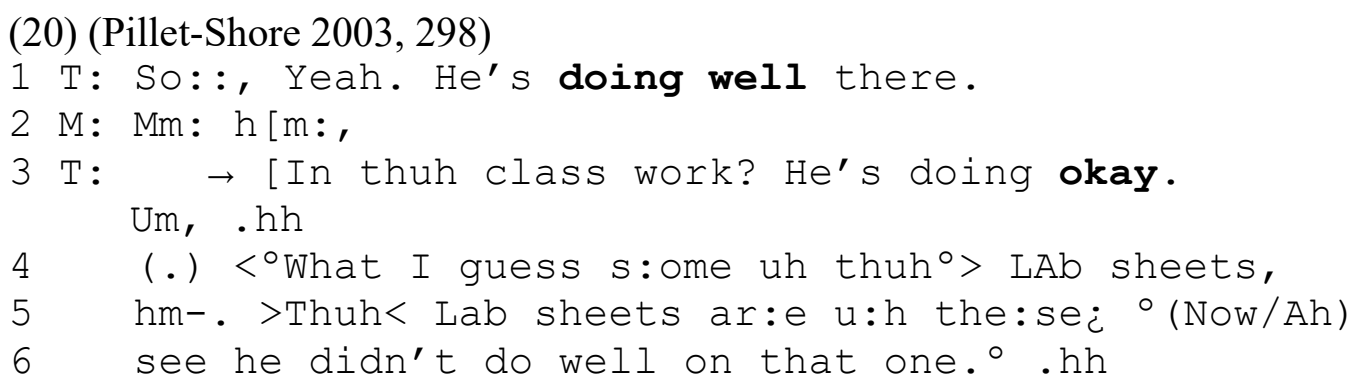

In line $1, \mathrm{~T}$ (the teacher) evaluates the student's performance in a subject as doing well. Subsequently, T assesses the same student's class work as doing okay. However, unlike previous examples where an okay assessment is seen as requiring no further explanation, T goes on to describe how the student didn't actually do well on some of the class work. According to Pillet-Shore, in this case the doing okay assessment takes on a degraded value compared to the previous doing well assessment. Therefore, okay assessments can sometimes take on a graded or relative value when compared with other assessments in close proximity.

Pillet-Shore also suggests that other features of talk such as prosody may play a role in the perceived quality of an okay assessment, but does not pursue this hypothesis in detail. Similar to permission okay, analysis of preference structure in assessments can shed some light on this topic. Because negative assessments are generally dispreferred forms of talk, they carry telltale signs of dispreference such as delays, hesitations, 
prefaces, repairs, token agreements, and sound lengthening (Pomerantz, 1984). Therefore, if we assume that production of a downgraded/negative okay will be a dispreferred action, then it will most likely be accompanied with the marked signs of dispreference. In excerpt (20), evidence of this can be seen with T's production of the hesitation markers "Um, .hh (.)" directly after the downgraded okay assessment.

\subsection{Response Token Okay}

According to Müller (1996) cited in Gardner (2001: 13), a response token is a neutral monitoring response which claims that talk by another has been acknowledged, perhaps agreed with or understood, or treated as news or not news. Okay is sometimes used by listeners in this capacity to acknowledge the receipt of an utterance by providing a minimal response. In the case of okay, this minimal response can come in two different varieties: it can either respond to an ongoing/incomplete utterance as a continuer token, or it can respond to a complete utterance as an acknowledgement token.

A continuer token indicates that an activity or topic is underway and bound to continue. It is normally produced by the recipient of a bit of talk while the talk is still in progress. This phenomenon is first coined by Yngve (1970) as backchannel signalling. According to Yngve, backchannel signals are a method for listeners to give feedback to speakers without interrupting. Schegloff (1981) revises Yngve's interpretation of backchannel signalling by proposing the idea of continuers. A continuer is an utterance that listeners make to show that they acknowledge that an extended unit of talk is underway, and is not yet complete. Schegloff argues that, unlike the relatively passive 
backchannel signals described by Yngve, listeners use continuers as an active form of participation in talk. Continuers are used to explicitly display the understanding that it is not one's turn to talk, and that the speaker should continue. Excerpt (21) shows an example of okay being used as a continuer by a student in an academic advising session.

(21) [CS2; 4:19-25] (Guthrie, 1997; 404)

$1 \mathrm{~A}$ : and this: : since this is now a prep, [you're=

$2 \mathrm{~S}: \quad$ [Oka:y, ]

$3 \mathrm{~A}:$ =gonna hafeta repeat that too.

This instance of okay can be classified as a continuer because A's talk is neither syntactically or intonationally complete when the okay token is produced by S. Therefore, this is a case of S acknowledging the ongoing turn produced by A. Gardner (2001) explains that unlike continuers, true acknowledgement tokens tend to come from a listener after an utterance from the speaker has some combination of grammatical, intonational, or pragmatic completeness. True acknowledgement tokens retrospectively claim receipt of a previous turn. If the okay token in excerpt (21) had been spoken by S after A had completed their entire utterance, it would be considered an acknowledgement token rather than a continuer.

The frequency at which okay appears as a continuer is rather insignificant compared to other tokens frequently used as continuers. Guthrie (1997), for example, proves this point by in her study which attempts to differentiate continuer and acknowledgement functionality between $\mathrm{mmhmm}$ and okay tokens. In her study, Guthrie examines a corpus of genuine academic advising sessions and uses the following metric 
to determine if a token is a continuer or not: (1) The token occurs in the middle of another speaker's turn. These cases are generally counted as continuers. (2) The token appears at a syntactic completion point. These cases are mixed between acknowledgement tokens and continuers; they require close examination of the surrounding interaction to determine.

(3) The token appears at both an intonational and syntactic completion point. These cases are generally acknowledgement tokens. Out of 138 cases of okay tokens in Guthrie's data, only 6 were counted as continuers. Guthrie concludes that although okay can occasionally appear as a continuer, it is far more likely to appear at syntactic and intonational completion points, making it more akin to acknowledgement of a previously finished utterance in most cases. Likewise, Filipi and Wales (2003) only count 5 cases of okay tokens being used as continuers out of nearly 200 occurrences in their data. This corroborates with Guthrie's findings and indicates that although okay can occasionally occur as a continuer in conversation, it is relatively rare when compared to other tokens more commonly used as continuers such as mmhmm.

\subsection{Summary of the Functions of Okay}

By reviewing the literature on okay, I have established that there are at least 7 general categories of okay functions recognized in the literature. There are 18 subcategories recognized within these 7 general categories. Some researchers classify the functions of okay in an even finer, more compartmentalized manner. For example, some make distinctions between functions based on where the token appears in a sequence, or whether a transitional okay token encompasses a vertical (within the same task) or 
horizontal (between different tasks) phase shift. Therefore, it would be possible to define an even more detailed taxonomy of the functions of okay, but the current study will focus on the categories described in this section.

Table 2.1 is a list of the discourse/pragmatic functional categories of okay that are identified in the literature.

\begin{tabular}{|c|c|c|}
\hline Main Function & Sub-Function & Description \\
\hline \multirow{3}{*}{$\begin{array}{l}\text { Transitional } \\
\text { Okay }\end{array}$} & $\begin{array}{l}\text { Speech/Action Shift } \\
\text { Marker }\end{array}$ & $\begin{array}{l}\text { Marks transitions between speech and } \\
\text { physical action. }\end{array}$ \\
\hline & Termination Inducer & $\begin{array}{l}\text { Aids in forcefully terminating } \\
\text { undesired/uncomfortable topics. }\end{array}$ \\
\hline & $\begin{array}{l}\text { Topic/Action Shift } \\
\text { Marker }\end{array}$ & $\begin{array}{l}\text { Marks transitions between different topics } \\
\text { and actions. }\end{array}$ \\
\hline \multirow[t]{6}{*}{ Monologic Okay } & Textual Marker & $\begin{array}{l}\text { Marks shifts in discourse within } \\
\text { monologic speech. }\end{array}$ \\
\hline & Pre-Closing & $\begin{array}{l}\text { Leads toward the inevitable closing of } \\
\text { monologic speech. }\end{array}$ \\
\hline & Attention Getter & $\begin{array}{l}\text { Initiates new monologic discourse and } \\
\text { signals to the audience that their attention } \\
\text { is needed. }\end{array}$ \\
\hline & Elaboration Marker & $\begin{array}{l}\text { Highlights and draws attention to a certain } \\
\text { point within monologic speech. }\end{array}$ \\
\hline & Hesitation Marker & $\begin{array}{l}\text { Used during monologic speech when the } \\
\text { speaker is having difficulties and trying to } \\
\text { reorient themselves or resolve a problem. }\end{array}$ \\
\hline & Response Elicitor & Used during monologic speech to check if \\
\hline
\end{tabular}




\begin{tabular}{|c|c|c|}
\hline & & listeners have anything to say or ask. \\
\hline $\begin{array}{l}\text { Ironic/Sarcastic } \\
\text { Okay }\end{array}$ & $\mathrm{N} / \mathrm{A}$ & $\begin{array}{l}\text { Shows contempt or feigns } \\
\text { surprise/deference in response to a } \\
\text { statement, action, or situation that is } \\
\text { perceived as foolish, offensive, or } \\
\text { otherwise worthy of derision. }\end{array}$ \\
\hline \multirow{3}{*}{$\begin{array}{l}\text { Tag Question } \\
\text { Okay }\end{array}$} & Confirmation Check & $\begin{array}{l}\text { Checks listener understanding of a } \\
\text { statement. }\end{array}$ \\
\hline & Command Softener & $\begin{array}{l}\text { Changes a command into question form. } \\
\text { Used as a politeness strategy for reducing } \\
\text { imposition. }\end{array}$ \\
\hline & Appeal to Solidarity & $\begin{array}{l}\text { Alleviates the fear of the listener, reassures } \\
\text { and/or to elicits cooperation. }\end{array}$ \\
\hline \multirow{2}{*}{ Permission Okay } & Permission Seeking & Seeks permission or consent. \\
\hline & Permission Giving & Gives permission or consent. \\
\hline \multirow[b]{2}{*}{$\begin{array}{l}\text { Assessment } \\
\text { Okay }\end{array}$} & $\begin{array}{l}\text { Standalone } \\
\text { Assessment }\end{array}$ & Assesses something as fine/unproblematic. \\
\hline & Graded Assessment & $\begin{array}{l}\text { Assesses something in relation to another } \\
\text { assessment in close proximity, potentially } \\
\text { changing the level of quality represented } \\
\text { by okay. }\end{array}$ \\
\hline \multirow{2}{*}{$\begin{array}{c}\text { Response Token } \\
\text { Okay }\end{array}$} & Continuer & $\begin{array}{l}\text { Spoken by a listener to indicate to a } \\
\text { speaker (during the speaker's turn) that the } \\
\text { speaker should continue talking. }\end{array}$ \\
\hline & $\begin{array}{l}\text { Acknowledgement } \\
\text { Token }\end{array}$ & $\begin{array}{l}\text { Acknowledges unproblematic receipt of a } \\
\text { previous utterance. }\end{array}$ \\
\hline
\end{tabular}

Table 2.1: The Discourse/Pragmatic Functions of Okay 


\section{Chapter 3}

\section{Research Methods}

In the previous chapter, I discussed the existing research on okay in order to establish a taxonomy of its discourse/pragmatic functions. The current chapter describes the research questions I ask based on this taxonomy, the data I analyse to answer the research questions, and the participants who took part in the research.

\subsection{Research Questions}

The primary objective of this research is to find out how Japanese speakers use the word $o k k \bar{e}$ in a discourse/pragmatic sense. To address this objective, I ask two research questions:

RQ1. RQ1. Of the discourse/pragmatic functions of English okay described in chapter 2 and listed in table 2.1, which functions are common to both English okay and Japanese $o k k \bar{e}$ ?

RQ2. Does Japanese $o k k \bar{e}$ have any discourse-pragmatic functions that are different from the established discourse/pragmatic functions of English okay?

In order to find answers to these research questions, I will analyse a corpus of naturalistic interactions between native Japanese speakers as well as native English speakers. 


\subsection{Data and Participants}

The data used for this study are drawn from a corpus of video/audio recorded interactions between Japanese native speakers across various locations on the Portland State University (henceforth PSU) campus. The aforementioned data come from a larger project called the PSU Mobile Learning Project, for which I was a camera operator and game text translator. The PSU Mobile Learning Project was the joint project of multiple academic departments across PSU, and supervised by Steven Thorne and John Hellermann. The project ran from 2014 to 2017, and focused on audio/video recording naturalistic language usage during augmented reality gameplay (augmented reality games are henceforth referred to as AR games) sessions in various languages: English, French, Hungarian, Japanese, German, and Spanish. AR games combine mobile technology such as smartphones and tablets with users' physical surroundings in order to provide an experience where users interact with a reality that is co-constructed by game design and real-life locations. See Thorne et al. (2015), Jones (2016), and Hellermann et al. (2017) for previous research that utilizes data from the PSU Mobile Learning Project.

The participants in the Japanese language recording session used for the present thesis were a mix of Japanese male and female study-abroad college students in their early 20s, visiting the PSU campus for the first time as a cohort. Their English proficiency was not formally measured for this research, but from my interactions with them, and observations their of English usage in the data, it can be assumed that the majority of the participants were beginner English speakers at the time of the recording. 
Prior to the recording session, the participants granted informed consent to be recorded and for the recordings to be used for research. The informed consent forms were provided and collected by the lead investigators of the PSU Mobile Learning Project, and not the author of the present study. The data were not recorded with any specific research objectives in mind. During my subsequent transcription of the recorded data, the unusual frequency of $o k k \bar{e}$ tokens throughout much of the spoken interactions inspired the current thesis.

For the duration of the video and audio recording session, the participants played an augmented reality game called Chrono Ops, which has players travel to 5 locations around the PSU campus and report on examples of green technology they find at the locations. The video recording of the participants consists of a combination of footage from cameras mounted to participants' heads and cameras held by researchers following the participants. Location 1 is a bike rack, location 2 is a set of solar panels on the roof of one of the campus buildings, location 3 is an electric car charging station that was being dismantled at the time, location 4 is a rainwater recycling system, and location 5 is a public transit station. The particular version of Chrono Ops used in these data gave the participants the option of recording their reports either using text, audio, or video. The participants initially played an iteration of the game that had Japanese text, and then played another iteration of the game that had English text. The original English language game text was written collaboratively by students and faculty in the 503 Design Collective, which is a group of PSU students, graduate students, and faculty focused on developing educational AR game content and analysing AR gameplay sessions. The 
Japanese language translation of Chrono Ops was partially created by members of the 503 Design Collective and finished by me. Appendix A can be referenced for the full game text in both Japanese and English.

Two English for Speakers of Other Languages (Henceforth ESOL) instructors and five researchers, including the author of the present study, facilitated the gameplay session. In the transcripts of the data, the researchers are labelled $\mathrm{Z}$ and $\mathrm{X}$, and the ESOL teachers are labelled $\mathrm{T}$ and $\mathrm{T} 2$. The ESOL instructors primarily answered questions from the students, helped when technical problems arose, and organized the groups. The researchers took turns following the various groups with a handheld camera and made sure that the recording equipment was functioning. The instructors and researchers moved about freely and were not assigned to any particular group. Therefore, data from the handheld camera does not depict any single group's playthrough from beginning to end. However, each group had at least one member with a head mounted camera, which recorded that group's entire playthrough from beginning to end. Although parts of the data from the handheld camera are occasionally used, the data analysed in this study primarily comes from the head mounted cameras because they offer a complete picture of each playthrough from beginning to end.

In the recorded data, the participants played the AR game in 6 groups numbered 1-6. The current study primarily utilizes the data recorded from group 1's playthrough of Chrono Ops as its corpus because the vast majority of this group's playthrough has been transcribed by me. A few sections from the playthroughs of group 2 and 3 are also utilized for the analysis. This transcription can be viewed in Appendix C. Group 1 
consists of two participants given the pseudonyms $\mathrm{C}$ and $\mathrm{M}$. Groups 2 and 3 consist of 3 members each. The members of group 2 are given the pseudonyms $\mathrm{O}, \mathrm{Y}$, and $\mathrm{S}$, and the members of group 3 are given the pseudonyms $\mathrm{A}$, R, and $\mathrm{H}$. Table 3.1 shows the pseudonyms used for the participants in each group. In the recorded data, all of the participants often speak a mix of English and Japanese; frequently switching from one language to the other from one turn to the next, or even sometimes within the same turn.

\begin{tabular}{|c|c|}
\hline Group & Pseudonym \\
\hline \multirow{2}{*}{ Group 1} & M \\
\hline & $\mathrm{C}$ \\
\hline \multirow{3}{*}{ Group 2} & $\mathrm{O}$ \\
\hline & S \\
\hline & $\mathrm{Y}$ \\
\hline \multirow{3}{*}{ Group 3} & A \\
\hline & $\mathrm{H}$ \\
\hline & $\mathrm{R}$ \\
\hline \multirow{3}{*}{ Group 4} & $\mathrm{E}$ \\
\hline & $\mathrm{G}$ \\
\hline & $\mathrm{Q}$ \\
\hline \multirow[t]{3}{*}{ Group 5} & $\mathrm{~K}$ \\
\hline & B \\
\hline & $\mathrm{N}$ \\
\hline
\end{tabular}




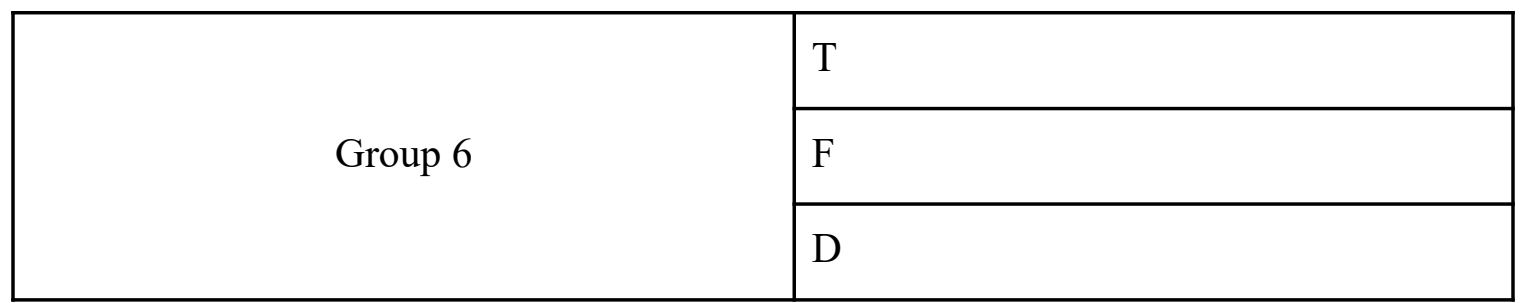

Table 3.1: Group Member Pseudonyms

Due to the bilingual nature of the data, I must consider what to count as an $o k k \bar{e}$ token and what to count as an okay token for the purposes of the analysis. Therefore, I use the following criteria to distinguish okke and okay: Tokens spoken by native Japanese speakers to other native Japanese speakers can potentially be counted as okke. The grammatical context surrounding each token is then considered when making the final judgement. If a token spoken by a Japanese native speaker is part of an English grammatical context, then it is counted as okay. Otherwise, the token is counted as okke. Pronunciation is not taken into account when considering how to classify a token.

Taking these criteria into consideration, 88 relevant tokens were identified as either $o k k \bar{e}$ or $o k a y$ within the group 1 data. 25 out of the 88 tokens were spoken by the researchers and instructors facilitating the gameplay. 63 tokens were spoken by the participants in group 1 . Out of the 63 tokens spoken by group 1, 49 of them were spoken between speakers of Japanese. 7 of the 49 tokens spoken by group 1 were within an English grammatical context. This leaves 42 tokens that are considered Japanese okke tokens for the purposes of comparing the functionality of okay with okke. A few additional tokens from other player groups (2 and 3) are taken into consideration when 
describing functions that are potentially unique to $o k k \bar{e}$, but the total number of tokens used in these two groups were not counted.

\subsection{Methods}

Before beginning my research on $o k k \bar{e}$, I transcribed the entirety of group 1's playthrough of Chrono Ops, and several portions of the other groups' playthroughs. The relevant portions of these transcripts are available in appendix C. During the transcription process, I noticed the frequent usage of $o k k \bar{e}$ tokens across all of the groups, as well as the presence of unusual clusters of $o k k \bar{e}$ tokens, so I decided to investigate this phenomenon as the subject of my thesis. In order to isolate samples of naturalistic $o k k \bar{e}$ usage, I listened to and watched the entirety of group 1's playthough of Chrono Ops multiple times. I recorded the timestamps of all audible okay and okkē usages, and then made a more detailed transcription of the surrounding context of each token using a modified version of Jefferson's (1984) conversation analytic notation. I collaborated with a Japanese native speaker for transcription phase of my data preparation to ensure accuracy. A detailed description of my notation style can be found in appendix B. The Japanese language romanization method used in the body of this thesis is modified Hepburn. The Japanese language portions of transcripts in the appendix are in Japanese script.

After developing a detailed transcript for the talk surrounding every applicable token, I examined the interactional environment and grammatical context surrounding each token in order to classify each one as either okay or okke. Then, I determined the 
primary function of each $o k k \bar{e}$ token via Conversation Analytic methods: I analysed the sequence of utterances and embodied actions surrounding each token, and came to a conclusion about the function of the token based on how the participants oriented to each token (Atkinson \& Heritage, 1984). For the ironic/sarcastic function of $o k k \bar{e}$, establishing its functionality in Japanese was highly dependent on describing articulation and prosody in detail, so I utilized interactional linguistic analysis with a phonetic focus to verify the phonetic properties of the tokens (Couper-Kuhlen \& Ford, 2004). This phonetic analysis was conducted with the aid of the audio imaging and analysis software PRAAT (Boersma \& Weenink, 2020). After analysing every applicable token within the data selection, a series of exemplars were chosen to illustrate how each discourse/pragmatic function described in chapter 2 is applicable (or not) to okkē. Additionally, distinguishing features and functions of $o k k \bar{e}$ not described in chapter 2 were described in detail along with exemplars. 


\section{Chapter 4}

\section{The Discourse/Pragmatic Functions of Okkē}

The following chapter will present findings from the analyses of $o k k \bar{e}$, and discuss evidence from the data in order to establish which discourse/pragmatic functions are common to both English okay and Japanese $o k k \bar{e}$, and then address features unique to okkē. In section 4.1, 1 will will briefly outline the cases in which there is no evidence within the data suggest that specific functions are common to both okay and okke. Then, the following sections will address cases in which there is evidence for okay and okke having common functionality. Finally, section 4.8 will address a function that is unique to okkē.

As with the discussion about the discourse/pragmatic functionality of okay, during the following analysis of $o k k \bar{e}$, it should be noted that any single $o k k \bar{e}$ token can simultaneously hold a multitude of functions. Although the following analysis may describe a given token as being transitional or ironic/sarcastic, that does not preclude the token from having other functions at the same time.

\subsection{Functions Not Found to be Applicable to Okkē}

No evidence within the data was found to suggest that okke has monologic, tag question, and permission functions in Japanese. Monologic okkē does not appear within the data because the participants do not engage in monologic communication within the span of the recording. Permission okke does not appear either, but this is perhaps also due to the lack of opportunities to ask permission. This does not rule out the possibility that 
okke can have permission and monologic functions; further research may reveal that these functions are used in different contexts from what occurs in the data. However, it is highly unlikely that $o k k \bar{e}$ is ever used as a tag question in Japanese simply because there are already a set of words such as ne and deshō that typically appear in the tag question position and have their own discourse/pragmatic functions. Furthermore, it is uncommon for syntactic operators such as tag questions to be borrowed from one language to another.

\subsection{Transitional $O k k \bar{e}$}

Transitional okke is used frequently by the participants in the data. These transitional okke tokens are used most often when speakers mark completion of an activity. Because the completion of an activity often coincides with a shift to the next activity, these can be interpreted as transitional in nature, similar to how pre-closing okay tokens work in English. The participants also frequently use transitional okke tokens when shifting between verbal and physical action, which is also a function of English okay tokens described by Merritt (1978). However, different from how transitional okay works in English, okkē is also used when participants transition between different physical actions outside of any interactional situation. Unlike the other transition functions described above, there is no evidence in the data of $o k k \bar{e}$ being used to forcefully terminate undesired topics, as okay sometimes is in English (Beach, 1995; Gaines , 2011). The following section will show evidence for the aforementioned subfunctions of transitional okkē. 
Okke often appears within the data as a means for players to mark the completion of a topic or activity, and thus open up the possibility of transition to subsequent topics or activities. In these cases, okke can be terminal to the activity, or in can act in a similar way to the pre-closers described by Schegloff and Sacks (1973). Excerpt (22) shows one such instance of okke being used by group 1 as they read the final game text and finish playing Chrono Ops.

(22) [JAPESLSep072016HC4,13: 02:58]

$01 \mathrm{M}$ : ®kimi no $(0.5)$ hoshi no: mirai wa sukuwareta $<®$ the future of the planet was saved by you

02 $(2.1)$

$03 \mathrm{C}:{ }^{\circ}$ (konkai iikata ga hade) ${ }^{\circ}$ that's a surprisingly extravagant way to put it

$04 \quad(1.6)$

05 C: okkē (0.3) finisshu; okay finish

$06 \quad(0.3)$

07 M: ya:y fini:shed

$\mathrm{M}$ reads the final sentence of the outro to the game on line 01 . Then, after a couple of short pauses and a comment about the style of the game text on line $03, \mathrm{C}$ declares $o k k \bar{e}$ finisshu on line 05. M orients to this by producing the celebratory token yay and saying finished, indicating that both players are in agreement that the game is finished at this point. 
One of the specific uses of transitional okay described by Kovarsky (1989) and Merritt (1978) is to release another person from an ongoing action. In short, this means saying okay in order to let somebody know that they can stop doing something. Okke appears to fulfill this role frequently within the data, as the following excerpt illustrates. In excerpt (23), $\mathrm{C}$ is inputting a response to the location 1 prompt, but is having trouble getting the word dioxide to appear in auto complete after M suggests that she use the phrase 'emit carbon dioxide'. In order to help $\mathrm{C}$ with her auto complete problem, $\mathrm{M}$ begins spelling the phrase aloud. $\mathrm{C}$ then releases $\mathrm{M}$ from this ongoing action of spelling aloud once the correct phrase appears in auto complete.

(23) [JAPESLSep072016HC4,6: 00:20]

$01 \mathrm{M}$ : 'emit carbon dioxide' no hou ga yokatta kamo 'emit carbon dioxide' would probably have been better

02 ((17 seconds omitted : M dictates 'emit carbon'; C repeats and inputs to phone))

$03 \mathrm{C}: \mathrm{di}: \mathrm{O}:$

04 M: diox:ide

$05 \quad(1.3)$

$06 \mathrm{C}:{ }^{\circ} \mathrm{di}:(0.7) 0:(0.6) \mathrm{xide}^{\circ}$

$07 \quad(0.6)$

$08 \mathrm{M}: \mathrm{d}$ i $\circ[\mathrm{x}$ i d ( $\mathrm{M}$ spells the word aloud)) 


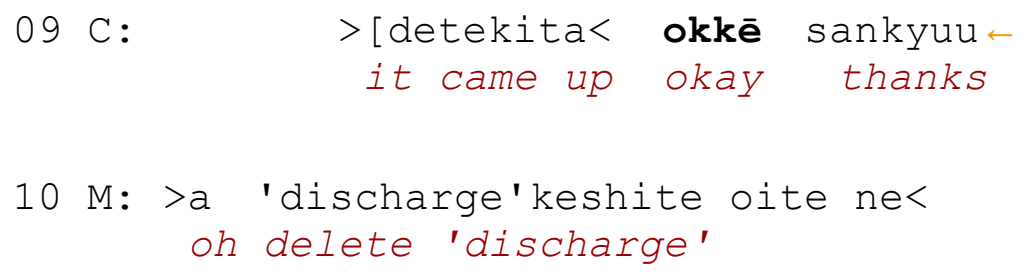

In line $01, \mathrm{M}$ suggests inputting the phrase emit carbon dioxide as part of the answer to the prompt. For the following 17 seconds, M slowly dictates emit carbon while $\mathrm{C}$ repeats aloud and inputs text into the phone. When it comes time to input dioxide on line 03, C displays disfluency marked by frequent pausing during her production of 'dioxide' on line 06 . $\mathrm{M}$ orients to this by initiating a repair on line 08 by spelling out the word one letter at a time. After M spells the word aloud up to the letter $o$, on line 9, C says that the word detekita (came up) and immediately follows-up with an okke token. At this point, $\mathrm{M}$ stops spelling dioxide when $\mathrm{C}$ says $o k k \bar{e}$. Because $\mathrm{M}$ did not stop spelling dioxide aloud after $\mathrm{C}$ said that the word came up, $\mathrm{C}$ oriented to this by explicitly releasing $\mathrm{M}$ from his ongoing action with an $o k k \bar{e}$ token, and subsequently thanking him for his help.

In addition to relieving others of ongoing activities, okkē can also be used to acknowledge that an action has been requested, whereby releasing the requester from the act of requesting. In these cases, okkē marks the shift between request and action. Again, this is very similar to one of the functions of okay described by Merritt (1978). Excerpt (24) shows an example of this sub-function of transitional okke used while group 1 searches for where they can make a note for location 2. Chrono Ops players are only able to make notes when they get sufficiently close enough to the designated location. This 
leads to players often checking when they are able to make a note. Between lines 01 and 04 of excerpt (24), $\mathrm{M}$ makes a request of $\mathrm{C}$ to check if a note can be made yet, and $\mathrm{C}$ acknowledges that request with an okkē token.

(24) [JAPESLSep072016HC4,6: 02:24]

$01 \mathrm{M}$ : e nooto >dekiru ka< kakunin shitoite eh check whether or not you can make a note

$02 \quad(0.3)$

03 M: ch $[e c k$

$04 \mathrm{C}:{ }^{\circ}\left[\mathrm{okk}_{\mathbf{e}}{ }^{\circ}\right.$ okay

$05 \quad(0.8)$

$06 \mathrm{M}$ : you can (0.2) make a note

In line $01, \mathrm{M}$ requests in Japanese that $\mathrm{C}$ check to see if it is possible to make a note yet. After a short pause on line 02, M begins repeating his question in English on line 03, and $\mathrm{C}$ responds with an okke token almost simultaneously on line 04 . This example is similar to what Merritt (1978) describes as an affirmative response granting a request.

Interestingly, a transitional function of $o k k \bar{e}$ that markedly differs from its English counterpart appears throughout the data: An okke that marks shifts between two physical actions, such as walking and stopping. Initially, I categorized this usage of $o k k \bar{e}$ as monologic because it often appears to be isolated from surrounding conversation, but then recategorized it as transitional because it doesn't happen in a quintessential 
monologic context where a single speaker is talking one-sidedly to another person or a group, and neither does it seem to appear in a strictly private-speech context where the speaker is not addressing another person. Rather, this usage of okke appears more to be a variation of the verbal/physical action shift marker described by Merritt (1978), but instead of marking shifts between words and actions, it simply marks shifts between two actions. Excerpt (25) shows an example of how the participants in the data use this particular function of transitional okkē. In this excerpt, $\mathrm{C}$ and $\mathrm{M}$ have finished submitting their response to the location 2 prompt, and are headed toward location 3 . At the start of the excerpt, the two members of group 1 are across the street from location 3 and about to use the crosswalk to cross the street as the signal changes to the countdown timer.

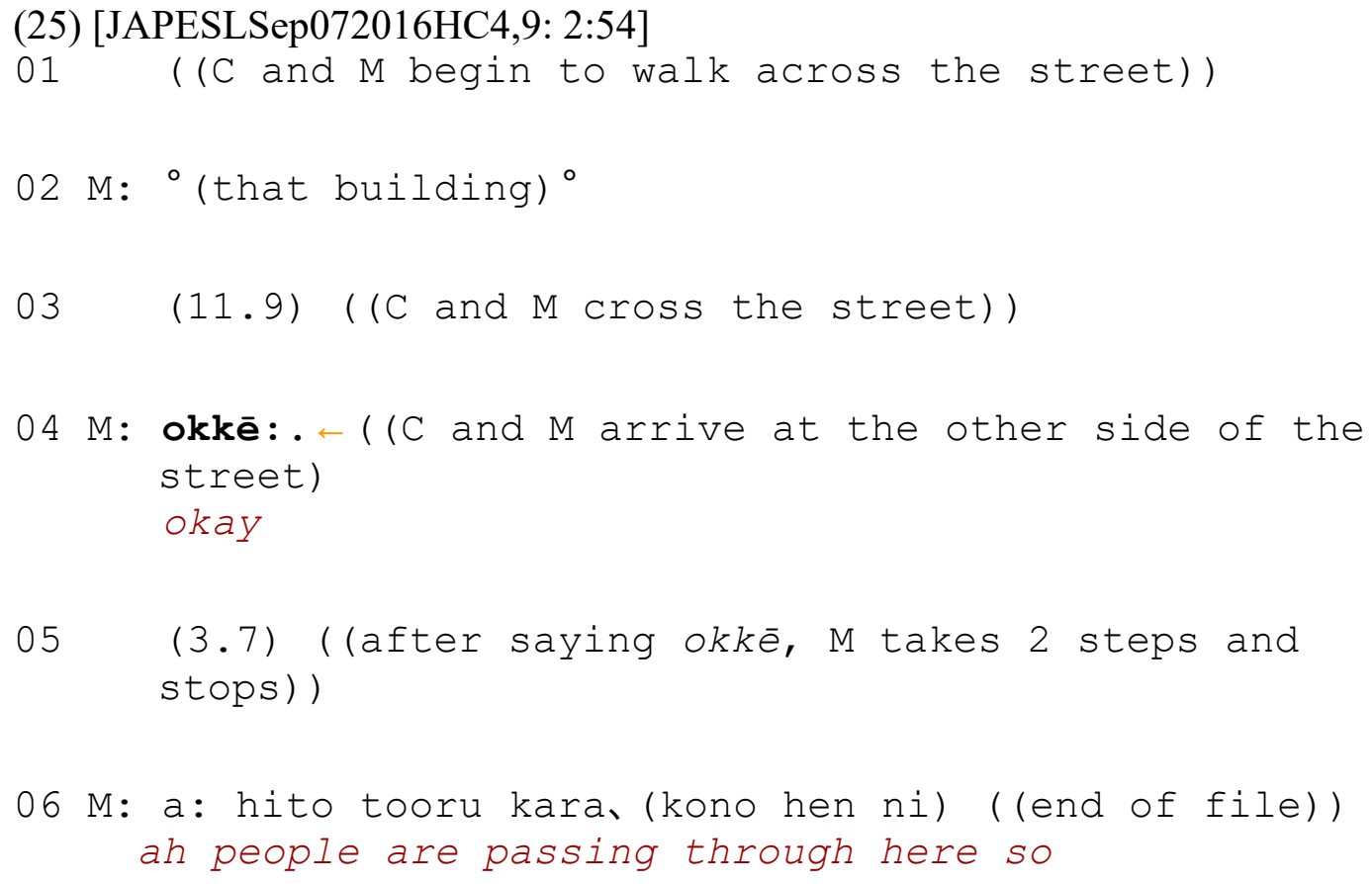

In excerpt (25), $\mathrm{C}$ and $\mathrm{M}$ spend about 12 seconds walking to the other side of the street without saying anything. Upon arriving at the other side of the street and stepping 
onto the sidewalk, M immediately says $o k k \bar{e}$ (line 04 ), takes two more steps, and stops (line 05). C stops walking as well at this point. Besides M's comment about that building, there is no ongoing talk between the two members of group 1 prior to their arrival at the other side of the crossing. This lack of surrounding talk in addition to the close proximity of the okke token to the change in physical action by both members of the group suggests that it may be used to mark transition points in physical action regardless of whether there is any ongoing talk. The phenomenon of groups verbally projecting a stop at the destination of an AR game has been previously documented by Jones (2016). According to Jones, upon arrival to their destination, AR game players often use a combination of gestures and verbal queues to establish a shared space for performing the task required by the AR game. Okke appears to be one of the tools utilized by the players of this AR game to establish this shared space.

Although establishment of a shared space upon arrival to a destination is one of the uses of physical to physical okke-marked transitions seen throughout the data, the physical action marked by an $o k k \bar{e}$ token doesn't necessarily have to be something as animated as walking: it can be something as simple as finishing inputting some text into a phone. Excerpt (26) shows such a case. In this excerpt the members of group 1 are at location 1 during the second iteration of the game, and are preparing to input their answer to the prompt into the iPhone that $\mathrm{C}$ is using. $\mathrm{M}$ suggests that they enter the same answer as in the first iteration of the game, and $\mathrm{C}$ agrees. $\mathrm{M}$ does not attend to $\mathrm{C}$ or her phone while she inputs the answer. 
(26) [JAPESLSep072016HC1.5: 06:43]
$01 \mathrm{M}$ : >injanai< (0.2) same demo
>it's fine< even if it's the same
$02 \mathrm{C}:{ }^{\circ}$ same de iikka ${ }^{\circ}(0.7)$ jaa:
is it fine as the same thing? ${ }^{\circ}$ alright
03 (4.0) ( ( $\mathrm{C}$ begins to input text into the phone while dictating aloud))
$04 \mathrm{C}$ : we: ( (C inputs text into phone while dictating aloud))
$05 \quad(4.5)$
$06 \mathrm{C}:{ }^{\circ}(\mathrm{ed})^{\circ}($ ( $\mathrm{C}$ inputs text into phone while dictating aloud under her breath))
$07 \quad(3.8)$
$08 \mathrm{C}:{ }^{\circ}(\text { dent })^{\circ}((\mathrm{C}$ inputs text into phone while dictating aloud under her breath))
$09 \quad(2.1)$
$10 \mathrm{C}:{ }^{\circ}$ to: ${ }^{\circ}$ ( ( $\mathrm{C}$ inputs text into phone while dictating aloud under her breath))
$11 \quad(0.6)$
$12 \mathrm{C}:{ }^{\circ}()^{\circ}((\mathrm{C}$ inputs text into phone while dictating aloud under her breath))
$13(7.1)$

14 C: okkē $\leftarrow$ ( (C shifts hands on phone $)$ ) okay 


\section{5 (1.6) ((M shifts his stance and attends to the iPhone)) \\ $16 \mathrm{C}$ : ${ }^{\circledR}$ the advantage is that we have $\mathrm{a}^{\circledR}(0.9)$}

In line $01, M$ reassures $C$ that it's fine to input the same answer that was used during the first iteration of the game, and $\mathrm{C}$ agrees to this in line 02 . What follows between lines 03 to 13 is about 30 seconds of $\mathrm{C}$ inputting text into the iPhone while quietly dictating aloud what she is inputting. During this 30 seconds, $\mathrm{M}$ looks around and does not attend to the phone. On line 14, C says okke in a noticeably louder voice than the preceding dictation and shifts her thumbs away from the screen. Following C's okkē token and hand movement, $\mathrm{M}$ shifts his stance and begins attending to the phone on line 15 . What follows on line 16 and beyond is a collaborative review and revision of the text that $\mathrm{C}$ entered. M's response to C's okkē token on line 15 can be interpreted as him orienting to the token as an indicator of activity change: In this case two physical activities have ended at the $o k k \bar{e}: \mathrm{C}$ is done inputting the text, and $\mathrm{M}$ is done waiting for the text to be input. Again, there is no ongoing talk leading up to the okke token, so the utterance of this token is likely to correspond to the completion of the ongoing action. The okke token is also oriented to as a mutual shift of activity by both participants, so this suggests that it is transitional in the dialogic sense and not the monologic sense. The okke token seen in excerpt (26) might also be interpreted as private speech that is said for the benefit of those listening. Japanese occasionally features sentences of this type, often marked with the sentence particles $k a$ ne or ka na. The example in question does not feature these sentence particles, but the $o k k \bar{e}$ token may be similar in function. 
In summary, evidence from the data suggests that transitional okke can mark the boundaries between topic/action and speech/physical action in same way that okay can. Additionally, unlike okay, okkē seems to be able to mark boundaries between different physical activities completely independent of other talk. Concerning the functions of okay that were not found in the data on $o k k \bar{e}$, there were also no highly routinized sections of talk within the data, so it is not known whether or not $o k k \bar{e}$ can be used to mark the trajectory of routinized discourse. The data also do not show any instances of okkē being used as a way to actively force topic/activity change. This lack of functionality for forcing topic change could possibly be attributed to the fact that Japanese culture/language has different methods of dealing with discomfort in conversation; confrontational and direct language is usually not the path taken out of an uncomfortable situation. This difference in communication strategies has been documented by Furukawa (2014), who shows that native Japanese speakers may be inclined to endure uncomfortable situations while projecting a cool and calm exterior instead of engaging in direct confrontation. Even if they were upset and felt like telling the other person to shut up, the native Japanese speakers in Furukawa's study reacted to adverse situations by providing minimal responses and waiting for the situation to end instead of trying to force some sort of change.

\subsection{Ironic/Sarcastic Okkē}

As described in section 2.3, okay and other English response tokens sometimes take on a sarcastic/ironic character when the speaker wishes to express disdain/contempt 
or feign deference. Evidence from the data suggests that $o k k \bar{e}$ is also capable of taking on a sarcastic/ironic character. Humor and irony tend to differ greatly between languages, so this finding is somewhat unexpected. A single instance of sarcastic/ironic okkē appears in the data after group 1 finishes playing the the AR game once, and are told by the researchers that they have to play another iteration of the AR game with English instructions. Most of the students were cold and hungry at this point, so several groups including group 1 complained and made sarcastic comments in Japanese. Group 1 in particular had joked about being made to do the entire AR game a third time in German, and $\mathrm{C}$ had commented that doing the AR game again was tsum:annai (la:me). Excerpt (27) shows the talk that ensued once group 1 started heading toward the first location of the second iteration of the AR game (the bike racks in front of Neuberger). Prior to the excerpt, $\mathrm{M}$ asks $\mathrm{C}$ where they are headed. At this point neither player seems to be aware that the locations are the same for both iterations of the AR game.

(27) [JAPESLSep072016RC1.5: 1:25]

$01 \mathrm{C}:{ }^{\circ}$ (Neuberger) bike parking ${ }^{\circ}$

$02 \mathrm{M}:$ okkē $\leftarrow(($ figure 1$))$

$03 \quad(0.7)$

$04 \mathrm{C}:{ }^{\circ} \mathrm{e}^{-}{ }^{\circ}$ huh?

$05 \mathrm{M}:{ }^{\circ} \mathrm{e}^{\circ}$ same mata? (0.2) hah (0.6) baiku@bai (0.4)
huh same again? 


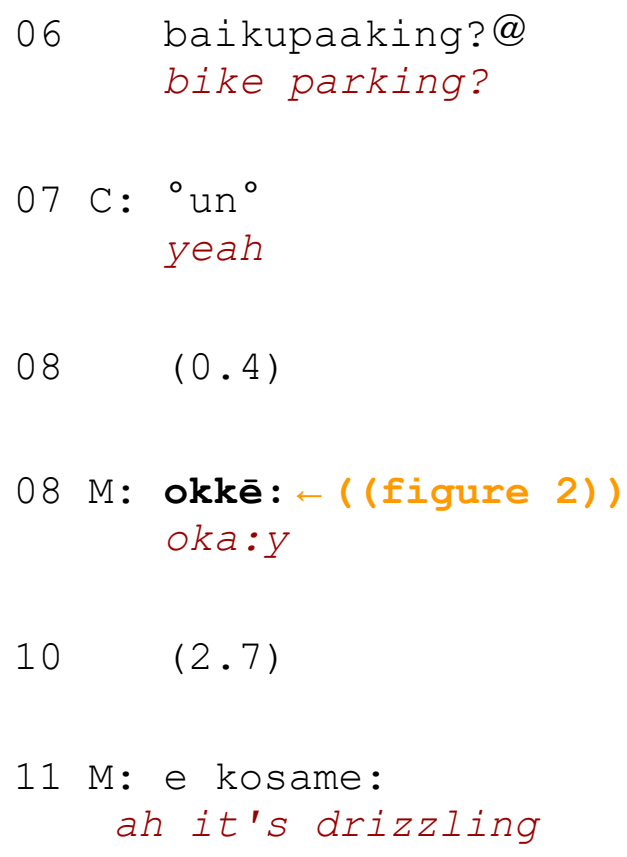

In line $1, \mathrm{C}$ reads aloud the name of the next location, the Neuberger bike parking area. Then, M confirms receipt of this information with a response token okkē on line 2 . After a short pause, $\mathrm{C}$ and $\mathrm{M}$ both utter the surprise tokens $e$ - (huh?). Subsequently, M expresses disbelief and exasperation that the location is exactly the same as in the first iteration of the game by producing a single laugh token hah, and then saying baiku paakingu in a halting, breathy laughing voice. $\mathrm{C}$ confirms this information on line 07 , and $\mathrm{M}$ responds with an uncharacteristically long okke token.

This particular $o k k \bar{e}$ token's unusual phonetic characteristics and proximity to laughter suggest that it has a sarcastic/ironic character similar to sarcastic/ironic okay tokens in English described by Beach (1993). The average okkē token produced by group 1 is approximately 0.42 seconds long; this particular $o k k \bar{e}$ on line 08 is approximately 0.64 milliseconds long, markedly longer than usual. This token's pitch curve and 
articulation are also unusual when compared to other $o k k \bar{e}$ tokens. Most $o k k \bar{e}$ tokens will have a pronounced pitch curve and a relatively short glottal stop at the $/ \mathrm{k}$./ portion.

However, in this instance, the pitch curve is flat, and the time spent on the /k./ glottal stop portion of the $o k k \bar{e}$ is longer than normal. The following figures show a comparison between the response token $o k k \bar{e}$ on line 02 and the assumed sarcastic/ironic okke token on line 08 . Figure 1 shows a visualization of an average non-sarcastic/ironic okkē token.

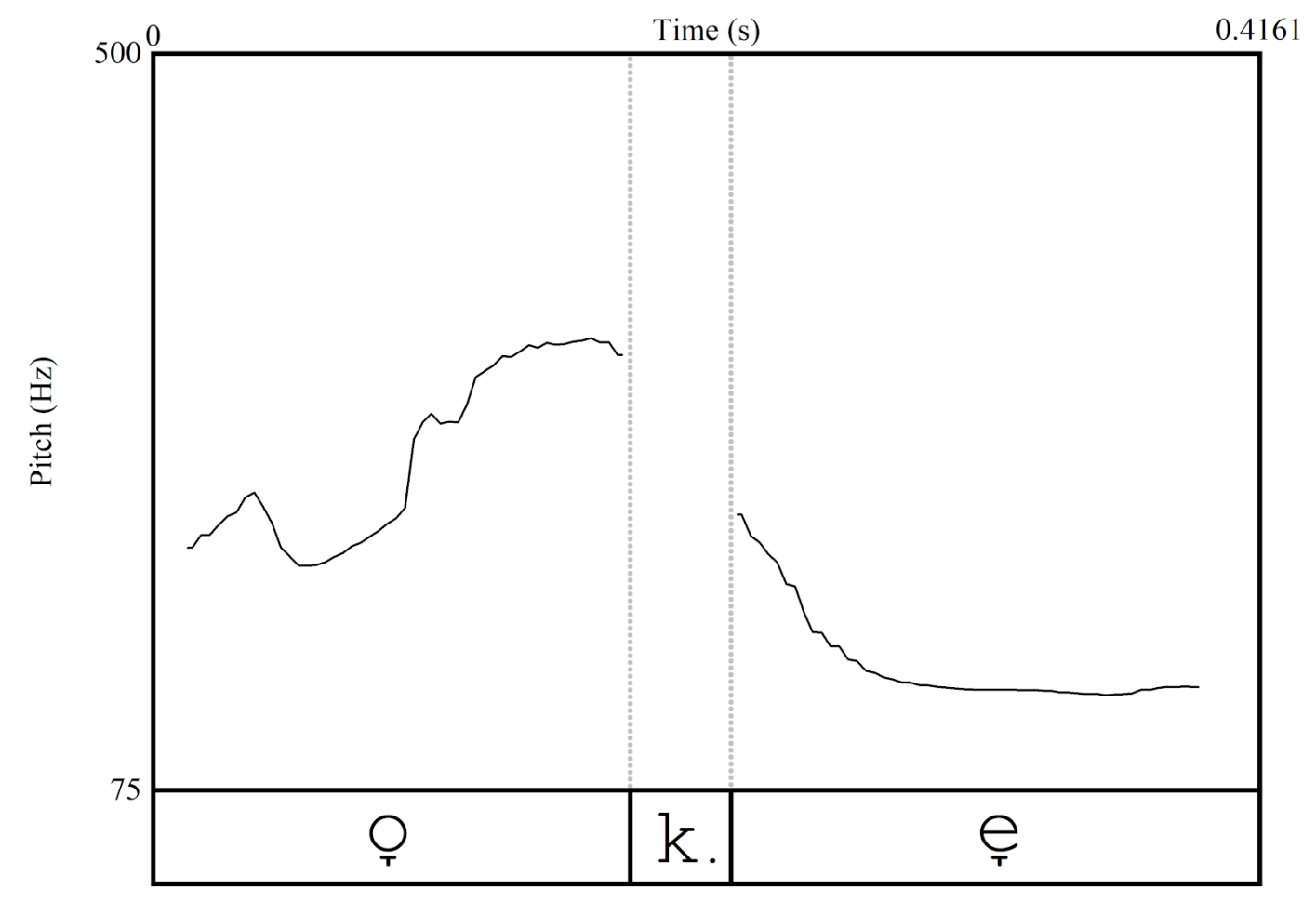

Figure 1: Pitch curve and articulation of $o k k \bar{e}$ spoken by M on line 2 of excerpt (27)

In the figure 1 , we can see that there is a pronounced pitch curve ranging from approximately $135 \mathrm{~Hz}$ to $335 \mathrm{~Hz}$, and a relatively short pause for the glottal stop $/ \mathrm{k}$./ 
consonant - this pause is approximately 0.04 seconds long. Compare this to the following sarcastic/ironic $o k k \bar{e}$ token on line 08 , shown in figure 2.

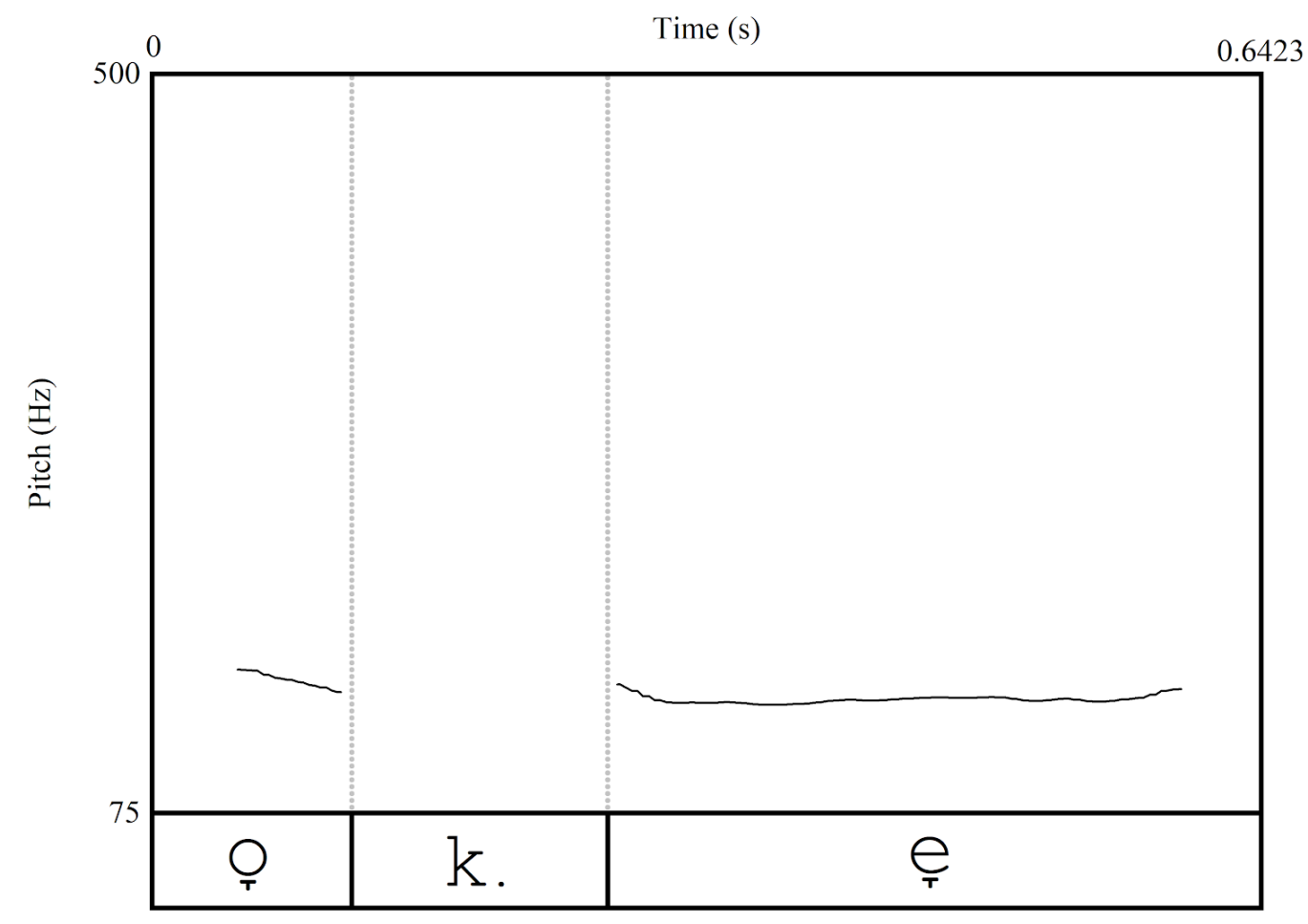

Figure 2: Pitch curve and articulation of okkē spoken by M on line 8 of excerpt (27)

Here, in figure 2 , the time spent on the $/ \mathrm{k}$./ glottal stop consonant is shown as approximately 0.140 seconds long, and the pitch range is shown as approximately $145 \mathrm{~Hz}$ to $155 \mathrm{~Hz}$. Both of the aforementioned properties are quite different from the response token $o k k \bar{e}$ shown in figure 1: the glottal stop is very long, and the pitch is unusually flat. Listeners tend to be able to distinguish clearly between 0.03 second differences in voicing onsets (Johnson, 2012), so the 0.1 second difference between the length of the glottal stops between the two okke tokens would be clearly noticeable to most listeners. The 
difference in the pitch curves would also likely be clearly noticeable to most listeners. The pitch range of the sarcastic/ironic okke token falls within a range that would likely be heard as completely flat: $145 \mathrm{~Hz}$ to $155 \mathrm{~Hz}$. In contrast, the pitch curve of the nonsarcastic/ironic okke token visualized in figure 1 ranges between $335 \mathrm{~Hz}$ and $128 \mathrm{~Hz}$, which is a clearly audible pitch curve. These phonetic features would likely result in the sarcastic/ironic $o k k \bar{e}$ token being perceived as a completely flat $o k k \bar{e}$ token with an unusually long pause for the $/ \mathrm{k}$./ glottal stop consonant - especially when compared to the other non-sarcastic/ironic $o k k \bar{e}$ token spoken in close proximity.

Similar to its counterpart in sarcastic/ironic English okay, sarcastic/ironic Japanese $o k k \bar{e}$ is produced with marked articulation, pitch, and length, which often puts these tokens in stark contrast to non-sarcastic versions of the same token, as described above. However, the use of a lengthened glottal stop consonant for sarcastic effect may be particularly unique to Japanese okkē. Several studies such as Aizawa (1985), Bruch (1986), and Tamori (1991) have classified similar usages of lengthened glottal stops in Japanese as marked as emphatic, specifically in Japanese mimetic words such as sappari (refreshed) and yukkuri (slow). Although okkē is not a mimetic word, a noticeably lengthened glottal stop can be interpreted as the speaker presenting the word as marked in some manner. In the excerpt shown above, the evidence suggests that $\mathrm{M}$ was likely expressing some marked (likely negative) nuance with his okkē token. Specifically, M may have been expressing disappointment with his marked production of $o k k \bar{e}$. 


\subsection{Assessment Okke}

Assessment $o k k \bar{e}$ tokens, which tend to represent an unproblematic assessment, appear occasionally within the data. As an assessment, okke usually occurs as a standalone token within its turn. This is different from English assessment okay, which often takes a more nuanced and graded assessment value dependent on other assessments in close proximity, and rarely appears as a standalone token (Pillet-Shore 2003). Because these particular $o k k \bar{e}$ tokens so often appear as the only utterance within a turn, it can sometimes be difficult to determine that they are acting as an assessment. However, sequential evidence from surrounding interactions can reveal that speakers orient to these particular $o k k \bar{e}$ tokens as unproblematic assessments.

The most illustrative exemplar of the assessment functionality of $o k k \bar{e}$ within the data comes from a stretch of talk where $\mathrm{C}$ and $\mathrm{M}$ assess the quality of an English sentence before submitting it. In excerpt (28), $\mathrm{C}$ and $\mathrm{M}$ are attempting formulate an English language answer to the location 4 prompt, which asks for players to think of alternative uses for collected rainwater. $\mathrm{M}$ is holding the iPhone and inputting the text, and has mentioned previously that he is unsure of the quality of the sentence English sentence that he is about to input. Four okke tokens appear within this stretch of talk, and all of them are either used to assess the sentence that $\mathrm{M}$ input into the iPhone, or to prompt an assessment of the aforementioned sentence.

(28) [JAPESLSep072016HC4,13: 00:31/JAPESLSep072016RC1.4: 01:46]

$01 \mathrm{M}$ : we stock (1.4) rain water:; (1.1) a:n[d
$02 \mathrm{C}:$
${ }^{\circ}\left[\mathrm{a}: \mathrm{nd} \mathbf{:}^{\circ}\right.$ 


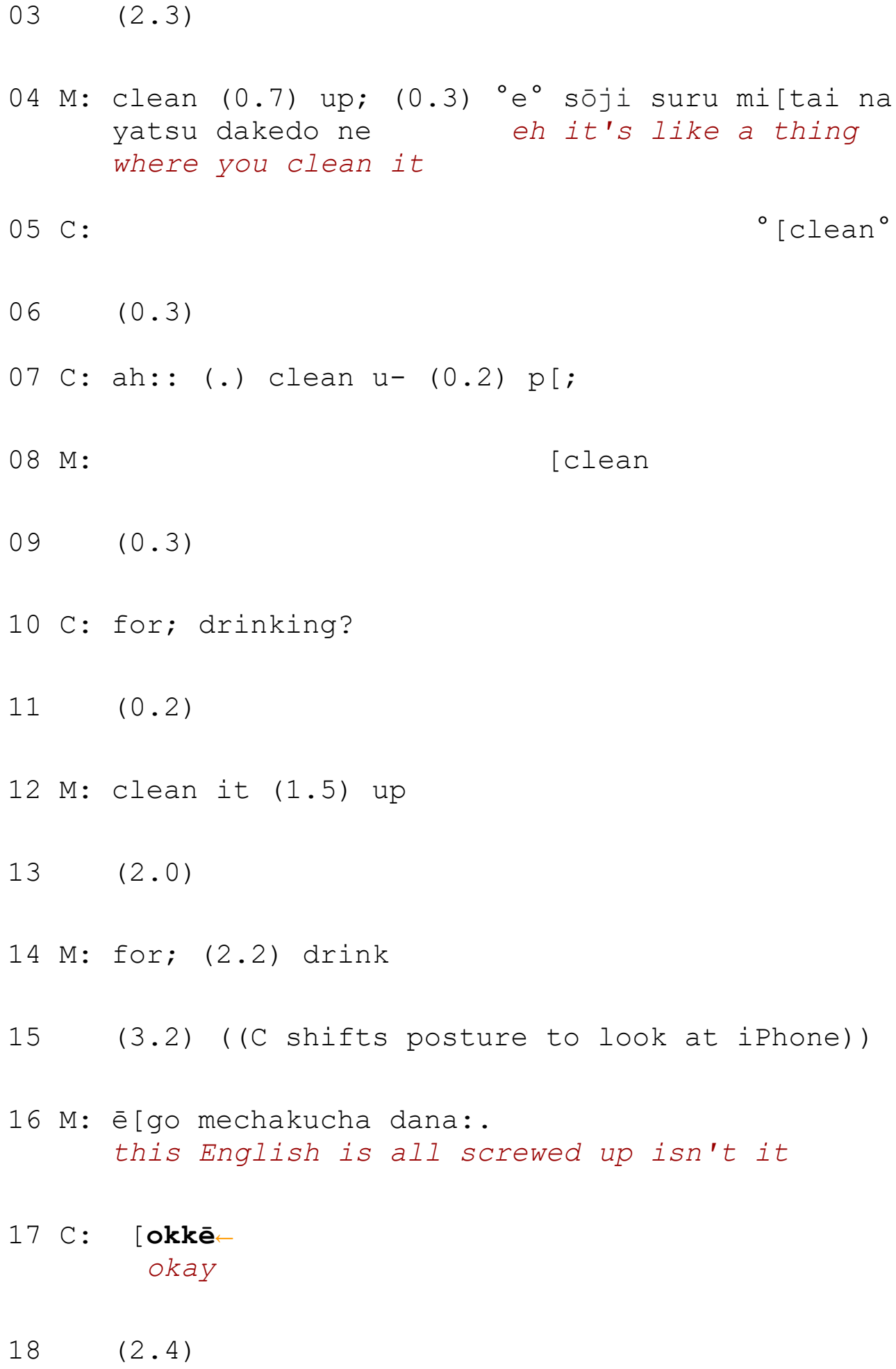




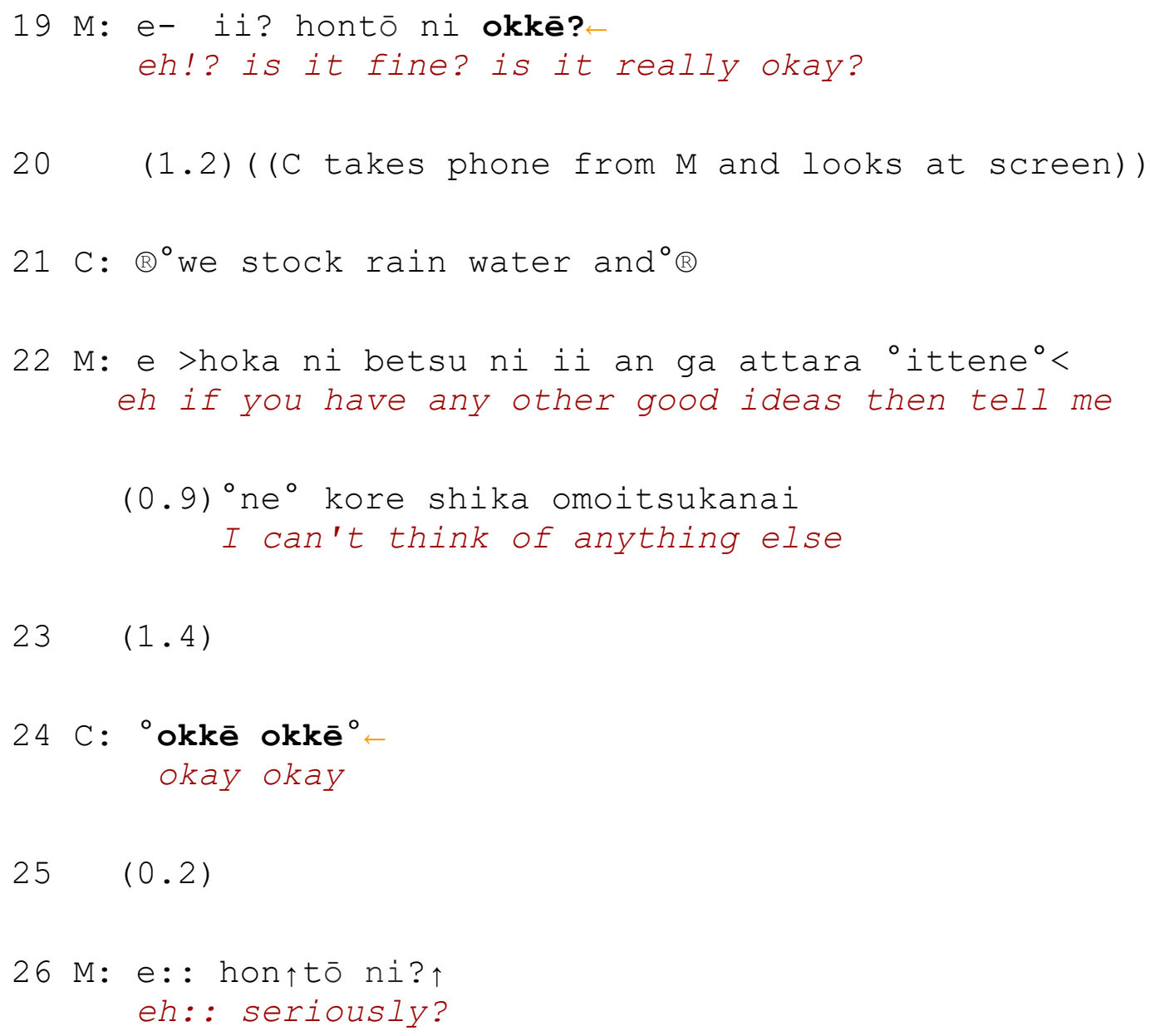

From lines 01 to $14, \mathrm{M}$ and $\mathrm{C}$ collaboratively speak the words of the sentence while $\mathrm{M}$ inputs the sentence into the iPhone. At this point, $\mathrm{C}$ is not yet attending to the iPhone. Then, during the 3.2 second silence on line 15, M finishes inputting the sentence into his iPhone while $\mathrm{C}$ shifts her posture to direct her gaze at the iPhone. Then, on line 16, $\mathrm{M}$ assesses the English used in the sentence as mechakucha (screwed up) while $\mathrm{C}$ simultaneously says $o k k \bar{e}$ on line 17. After a short pause, on line 19, M produces a sentence that questions the legitimacy of C's okkē token on line 17: 


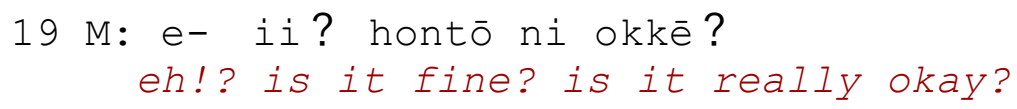

M's response on line 19 is especially significant because it implies that the assessment $i i$ (fine/acceptable) is equivalent to $o k k \bar{e}$, with both $i i$ (fine/acceptable) and okkē being in opposition to mechakucha (screwed up). After this, C rereads the sentence aloud on line 21, and $\mathrm{M}$ asks $\mathrm{C}$ if she has any other ideas for the sentence on line 22 . To this, $\mathrm{C}$ responds with two consecutive okkē tokens.

$$
\begin{aligned}
24 \mathrm{C}: & { }^{\circ} \text { okkē okkē } \\
& \text { okay okay }
\end{aligned}
$$

$\mathrm{M}$ again orients to the $o k k \bar{e}$ tokens uttered by $\mathrm{C}$ as having a positive assessment property, opposed to M's assessment of the sentence as mechakucha (screwed up). He does this by expressing doubt and questioning the authenticity of C's assessment.

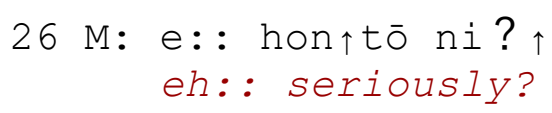

These points of evidence suggest that Japanese $o k k \bar{e}$ can indeed function as an assessment, and holds a positive assessment value that is equivalent to $i i$ (good/fine/acceptable/unproblematic) and opposite to mechakucha (screwed up).

As seen in excerpt (28), Japanese assessment $o k k \bar{e}$ 's ability to appear as the only word within its turn is markedly different from how English assessment okay works: 
generally, the only type of English okay token that tends to appear by itself within a turn is a response token. Assessment okay almost always tends to be part of a longer turn, and very rarely appears by itself. This can be seen in excerpt (29), which shows an example of the members of group 1 using English okay to assess the usage of the vocabulary item set on line 02 .

(29) [JAPESLSep072016HC4,8: 02:53]

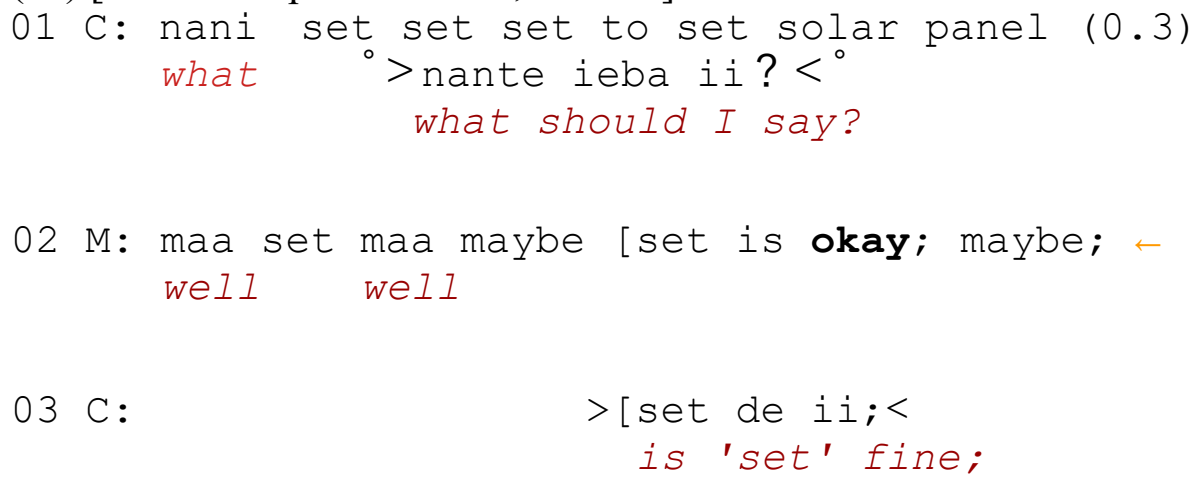

Tokens such as those shown in excerpt (29) cannot be counted as Japanese okkē because they follow English grammatical conventions by being connected to the English copula $i$ as a predicative adjective. When English okay tokens do assessments, they almost always appear in some variation of the above configuration: either accompanied by a form of the copula, or accompanied by the verb $d o$. This holds true not only in my data, but also when looking at the data used by Pillet-Shore (2003). Excerpt (30) shows another example of this phenomenon.

(30) [JAPESLSep072016HC4,2: 01:51]

$01 \mathrm{M}$ : everyone wa: :it $(0.6)$ huh huh huh huh::

$02 \quad(0.3)$ 


\section{T: it's okay I think you might all go all $\leftarrow$ different ways}

Here, again, the okay token is linked to a contracted form of the copula, and is used to assure $\mathrm{M}$ that the situation is unproblematic. This requirement of a copula or the verb $d o$ being connected to an assessment okay token ensures that it almost always appears as part of a longer turn.

In stark contrast to how English okay normally appears, Japanese okkē, regardless of its function, more often than not appears as the only word within its turn. This applies to $o k k \bar{e}$ when it is functioning as an assessment as well, although some less frequent exceptions such as hontoō ni okkē exist. Lines 17 and 24 of excerpt (28) are illustrative of this. This tendency for Japanese $o k k \bar{e}$ to appear in isolation raises a noteworthy issue that $o k k \bar{e}$ is more ambiguous in function and meaning to the analyst (not necessarily the participants) than English okay because it is rarely connected to other words that provide surrounding context. Before taking M's orientation to C's production of the tokens in excerpt (28) into account, I mistook the tokens as acknowledgement tokens. With English okay, it is common to have anaphoric expressions that link the token to some referent, and therefore give listeners some clue as to how the token is functioning. However, in Japanese, the okke token often does not get the same kinds of clues within the same turn, and often requires a broader contextual understanding of the situation to surmise its function and meaning. Part of the reason for this phenomenon could be the casual conversational nature of the word $o k k \bar{e}$; in casual settings, the Japanese copula is usually 
dropped, which leads to the word being used frequently as the only word within a turn (section 4.5 further elaborates on the casual nature of $o k k \bar{e}$ ). There is, in fact, not a single case of $o k k \bar{e}$ being accompanied by the Japanese copula within my data. Another possible reason for this phenomenon could be the frequent dropping of grammatical subjects in Japanese found throughout all styles of the language. These two factors potentially lead to many $o k k \bar{e}$ tokens appearing by themselves. Whereas an English turn would commonly include a subject, copula, and the okay token itself regardless of the speech style, a Japanese turn would most often omit both the subject and the copula, especially in casual speech, resulting in more standalone tokens in Japanese.

\subsection{Response Token $O k k \bar{e}$}

A response token can either be a minimal acknowledgement to a finished utterance, or a continuer, which is produced by a listener who is not taking the current floor, and encourages an ongoing stretch of talk to proceed. Within the data, okke often appears as an acknowledgement to a finished utterance, but never as a continuer. Frequently, these acknowledgement tokens appear to indicate unproblematic receipt of some explanation. The excerpt (31) shows one such example. In this example, as group 1 is walking toward location 4 for the second time, $\mathrm{M}$ is explaining to $\mathrm{C}$ while they are walking that a good use for rainwater is to give to plants, and not to drink. This is a marked revision from the first time $\mathrm{C}$ and $\mathrm{M}$ visited location 4, at which time they decided that a good use for rainwater would be to clean and drink it. This time around, $\mathrm{M}$ 
points out that giving the water to plants would actually be a better way to use the water than cleaning it and drinking it.

(31) [JAPESLSep072016RC1.6:05:06]

$01 \mathrm{M}$ : are jan amamizu dattara betsu ni sa, (.) tottokeba sa: (0.6) >ano shokubutsu ni agereba ii jan betsu ni (.) ore[ra ga nomanakute ii kara< it's like if we can just collect that rain water and like give it to plants and stuff it would be fine, ((C's change of state token)) 'cause it's not like we've gotta drink it ourselves, right?

$02 \mathrm{C}:$

$[\uparrow a::::::::::: \uparrow$

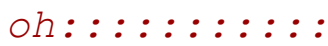

03 M: for plant dayo. (0.5) [ for nature dayo. (emphatic copula) (emphatic copula)

$04 \mathrm{C}:$

${ }^{\circ}\left[\right.$ okkē : ${ }^{\circ} \leftarrow$ okay: (15.3) ((the group continues walking to location 4))

On line $01, \mathrm{M}$ explains his proposal for the text to input for location 4, and $\mathrm{C}$ responds on line 02 with a very long $a$ token while $\mathrm{M}$ is still talking. This $a$ token is similar to English oh, which shows that the producer of the token has undergone a change of state in state of knowledge, awareness, information, or orientation (Heritage, 1984). When $o h$ and okay appears as a combination, it is often indicative of the receipt of a repair (Heritage, 1984). Interestingly, in excerpt (31) we see a okkē fulfilling a similar function. C produces the long $a$ token as M says that it would be fine to give the water to 
plants, and then $\mathrm{C}$ produces the $o k k \bar{e}$ token once $\mathrm{M}$ syntactically and intonationally completes an utterance with for plant dayo. The fact that the okke token comes at a syntactic and prosodic completion point after the receipt of a repair strongly suggests that it is acting as an acknowledgement token in this case.

As a side note, excerpt (31) underscores another property property of okke that may be tangentially related to its discourse/pragmatic functionality - formality, or lack thereof. Throughout all of the interactions between $\mathrm{C}$ and $\mathrm{M}$, they maintain a very casual speech style. This becomes especially apparent with M's talk in excerpt (31) because he uses jan, which is the very casual contracted form of janaika (right? isn't it?), and $s a$, an assertive and often masculine sentence particle typical in very casual settings. All throughout the data, okkē tends to appear in markedly casual interactional environments, suggesting okke is common in these environments, much like its English counterpart okay.

\subsection{Okkē Cascades: A Function Unique to Okkē}

The previous sections in this chapter analysed the discourse/pragmatic functions that $o k k \bar{e}$ shares with okay and briefly outlined which functions are not present in $o k k \bar{e}$, but are present in okay. The current section will attempt to describe a discourse/pragmatic function that is present in okke, but is not present in okay: the okke cascade ${ }^{1}$. This particular function of $o k k \bar{e}$ occurs as a specific way for multiple speakers to coordinate transitions as a group, and as such it is a sub-function of transitional okke. Unlike the previous sections that focused on okkē usage in group 1 only, this section will draw upon

1 The term okkē cascade was coined by Steven Thorne. 
select data points from player groups 2 and 3 as well as group 1. It should be noted that the majority of transitions in the data are not marked by okke cascades. However, the transitions that are marked by okke cascades are notable for how different they are from okay-marked transitions in English-only contexts.

As discussed in chapter 4.2, okke tokens feature prominently in the data as markers of transition points in action. For example, after a group completes an activity, but before moving on to the next activity, one or more members of the group frequently say $o k k \bar{e}$. However, oftentimes, these $o k k \bar{e}$-marked transition points involve coordinated okkē cascades where every member of the group repeats the token in turn; sometimes more than once per person. Most of the time during an $o k k \bar{e}$ cascade, okke is produced as a solitary token within its turn, but it is sometimes accompanied by other minimal tokens such as un (yeah). In order to shed light on exactly how Japanese okkē cascades function, the following section will attempt to describe in detail how groups of Japanese conversants coordinate activities and talk with okkē tokens.

Analysis of multiple okke cascades within groups 1, 2, and 3 throughout the data suggests that they tend to occur when a group has finished a collaborative task such as inputting an answer to a location prompt and getting ready to move on to the next location. This implies that $o k k \bar{e}$ cascades are both collaborative and transitional in nature. Excerpt (32) shows a minimal okke cascade occurring between the members of group 1. In this excerpt, $\mathrm{C}$ and $\mathrm{M}$ work together to come up with an English language answer to the location 2 prompt, which asks players to list the advantages and disadvantages of solar energy. At the point where the excerpt starts, $\mathrm{C}$ and $\mathrm{M}$ had already finished inputting 
the advantages, and begin working on inputting disadvantages. Both $\mathrm{C}$ and $\mathrm{M}$ have their gaze fixed on the screen of the iPhone at the start of the excerpt. The okke cascade starts on line 14 after the collaborative effort to find a suitable answer to the prompt comes to a close, and $\mathrm{C}$ finishes inputting the answer.

(32) [JAPESLSep072016RC1.6:00:19]

$01 \mathrm{C}$ : disadvantage is that the $(0.2)$ it is raining or (.) cloudy?

$02 \mathrm{M}$ : un yeah

$03(0.3)$

04 C: it's (0.9) nani:? ((looks up from screen and makes a rotating hand gesture)) wha: $t$ ?

$05 \mathrm{M}$ : ( (M looks up at C)) it doesn't work

$06 \quad(0.3)$

07 C: a(.) sore sore(.) sore ga iitakatta ah (.) that's it that's it (.) that's what I wanted to say

08 (1.9) (( $C$ looks down at phone and inputs text, $M$ also looks down at phone))

09 C: etto isn't umm

$10 \quad(0.9)$ 
$11 \mathrm{M}$ : tometeoke (.) meccha tsukaeru koko save that we can totally use that here $(0.3)$

13 C: work.

$14 \quad(1.5)$

\section{$15 \mathrm{M}$ : okkēe}

okay?

$16 \quad(0.4)$

17 C: okkē.

okay.

$18 \quad(1.2)$

$19 \mathrm{M}$ : okkēe :

oka:y

20 (1.4) (C taps the top corner of the iPhone screen)

21 C: no: (0.2) sorry $(0.5)^{\circ} I$ missed it ${ }^{\circ}$

22 (1.4) (C taps the top corner of the iPhone screen again, and then starts zooming in on the map with a finger gesture)

$23 \mathrm{M}:$ next is:

24 ( (C enlarges the map display on phone with a finger gesture))

25 ((C and M look closely at the iPhone)) 


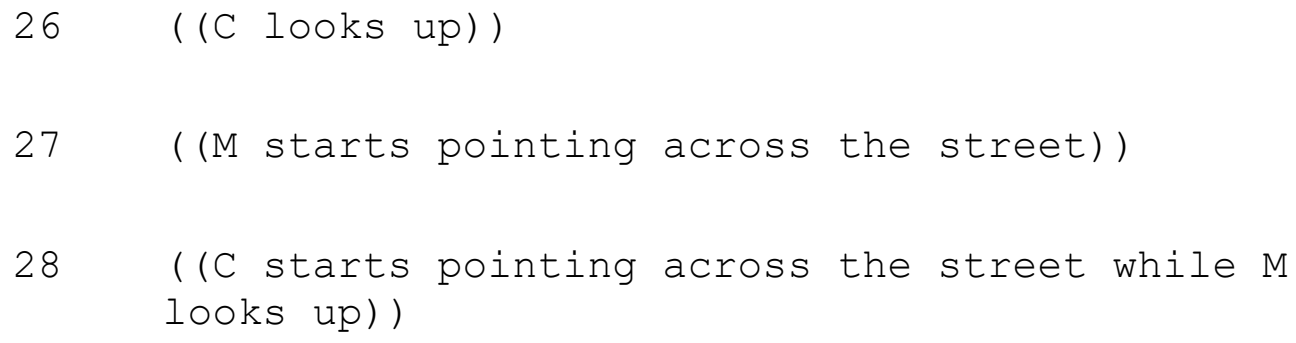

From lines 01 to 12, $\mathrm{C}$ and $\mathrm{M}$ collaboratively formulate an English response to the prompt: listing some disadvantages of solar power. In her attempt to formulate an answer, C provides the condition if it is rainy or cloudy, but then indicates that she does not know how to finish the sentence on line 04 by saying nani (what) while making a rotating hand gesture. $\mathrm{M}$ orients to this by helping her to finish the sentence with it doesn't work on line 05. C subsequently approves of M's contribution on line 07 by saying sore ga iitakatta (that's what I wanted to say), and begins inputting the suggested sentence while reading it aloud; eventually finishing on line 12 with the final word of the sentence: work. What comes next on lines 15,17 , and 19 can be considered a minimal okke cascade because it includes only three okke tokens: A token initiating the cascade produced by M, which is followed by an okke token produced by $\mathrm{C}$, and the cascade is finished by another token produced by $\mathrm{M}$ after a short pause. Immediately after the $o k k \bar{e}$ cascade, $\mathrm{C}$ attempts to find the next location on the map by tapping the top corner of the screen and using a zoom-in gesture, suggesting that she has oriented to the end of the cascade as a point of transition in the activity. Similarly, $M$ also orients to this as a transition point as indicated by his utterance on line 23: next is. What follows the okke cascade is a highly coordinated effort by both members of the group to find the next destination in the game. On lines 25 
through 28, both $\mathrm{C}$ and M look at the iPhone screen closely and then coordinate their bodily movements with each other to point at the physical location of the next destination on the map. The shift in behavior from inputting the answer to the prompt prior to the okke cascade and then to the subsequent coordinated search for the next destination suggests that the group members orient to the okke cascade as a place in time where transition in activity and group cooperation are relevant.

Although not universal to all okke cascades, moments of notable group coordination tend to occur more often than not after a cascade. As seen in excerpt (32), group members tend to converge upon a single task such as group wayfinding after an okkē cascade. Excerpt (33) from group 3's playthrough of the AR game illustrates that this phenomenon occurs in groups of 3 players as well as groups of 2 players. In excerpt (33), the members of group 3 collaborate to formulate an answer to the location 1 prompt, which asks players to list the advantages and disadvantages of riding bicycles to campus. A and $\mathrm{H}$ offer suggestions such as kābonfuttopurinto dakke (was it called a 'carbon footprint'?) and so: good for environment while R inputs the answer into the iPhone.

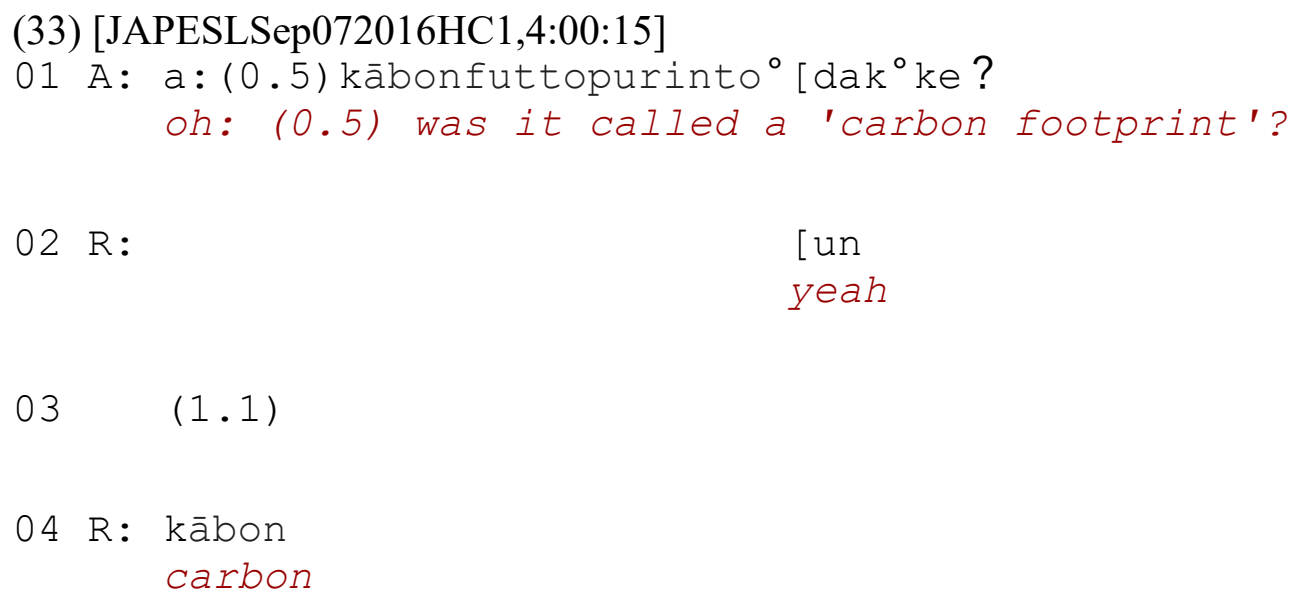




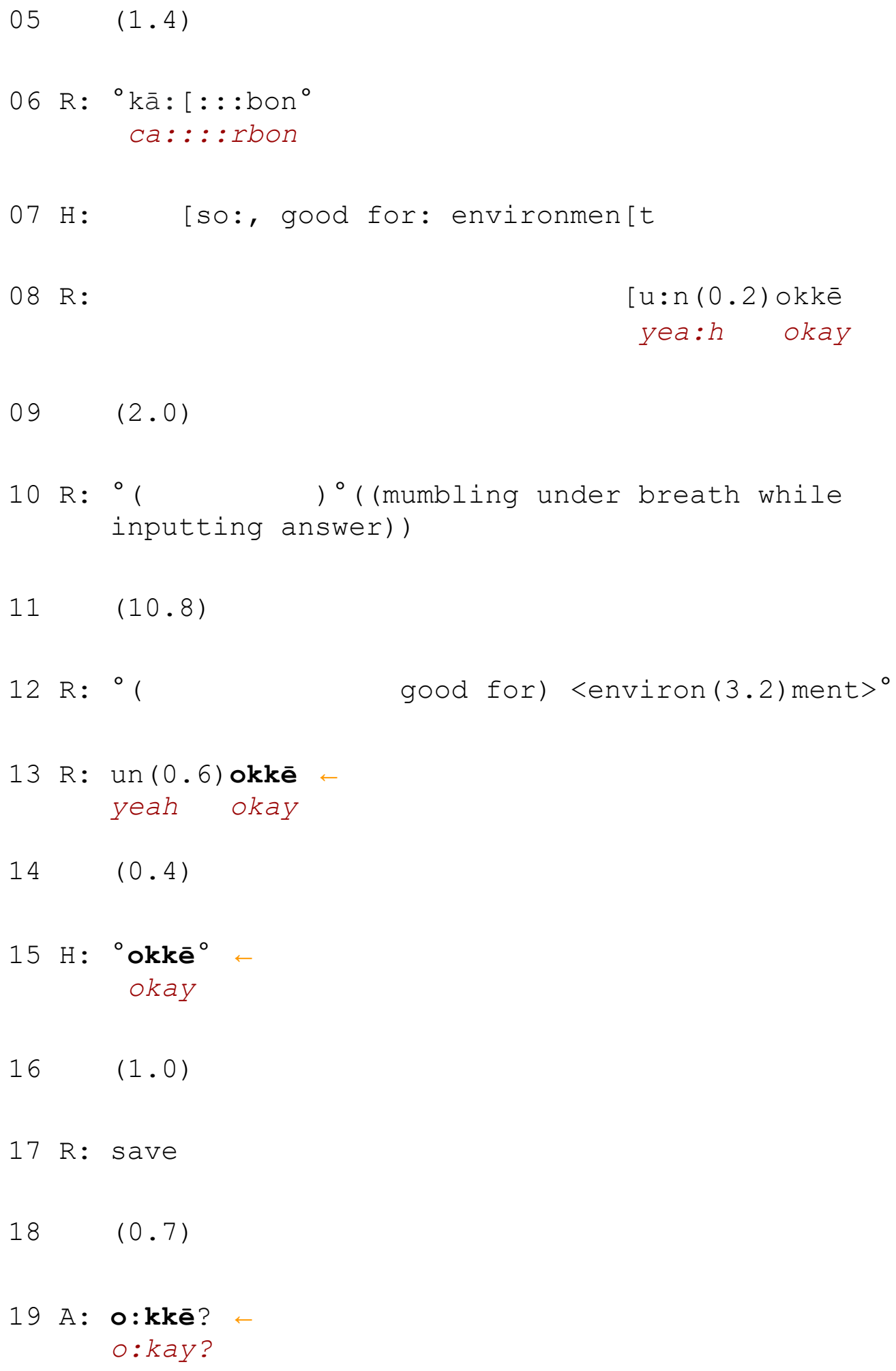




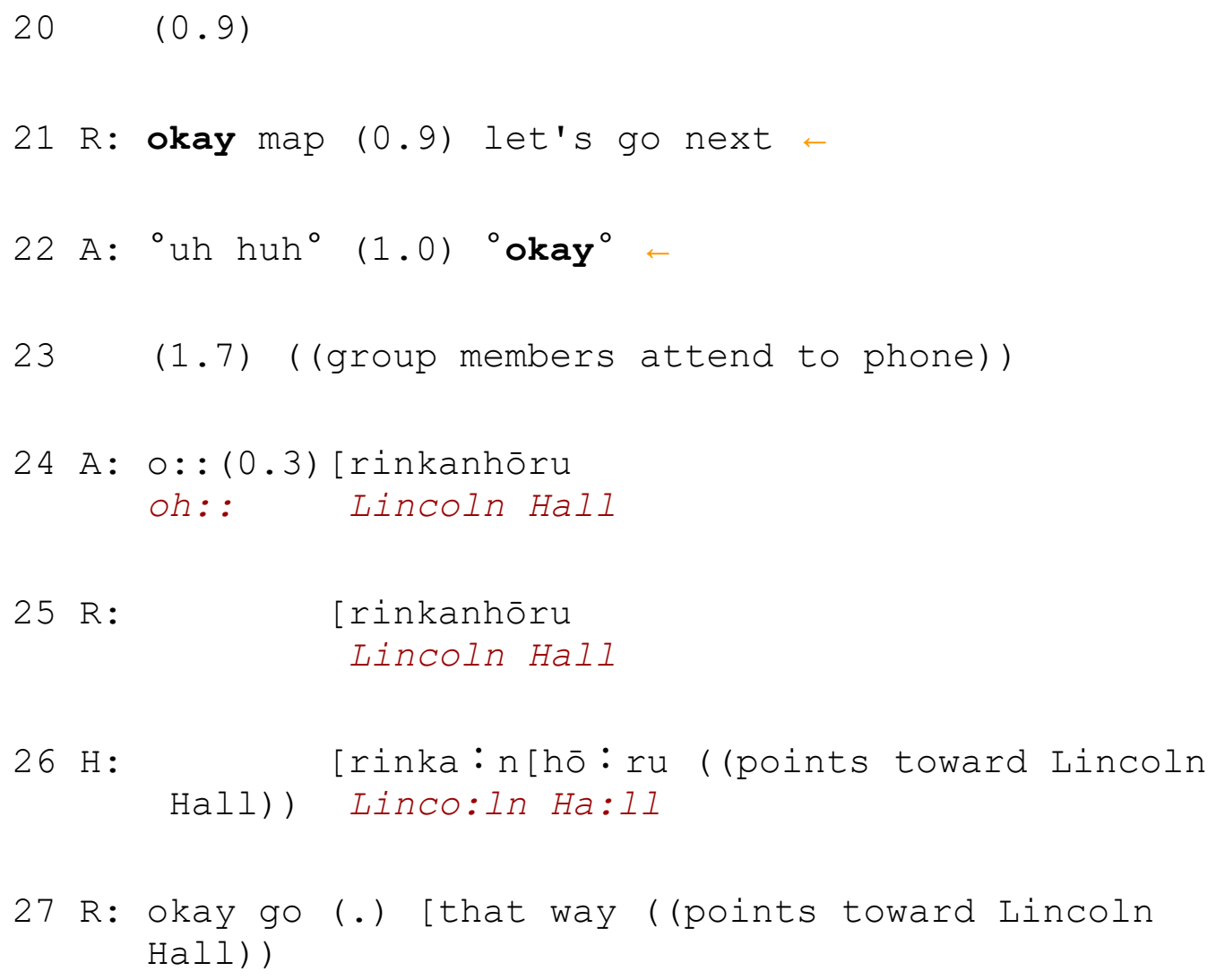

After acknowledging suggestions from both $\mathrm{A}$ and $\mathrm{H}, \mathrm{R}$ finishes inputting the answer to the prompt on line 13 , and marks this point with an $o k k \bar{e}$ token, which starts an okke cascade. In this case, the okkē cascade shown from lines 13 through 19 seems to trail off into an English continuation of the cascade from lines 21 to 22, where R and A produce okay tokens as part of longer, grammatically English turns. This shift towards an English grammatical context does not seem to affect what comes after the cascade: a coordinated effort by the members of the group to find the next location in the AR game. On lines 23 to 26 , the group members attend to the iPhone, and simultaneously say the name of the next destination: Lincoln Hall. Then, on lines 27 and 28, $\mathrm{H}$ and R point toward Lincoln Hall, and the group begins walking toward the destination. Again, there is 
a shift in behavior from collaboratively inputting the answer to the prompt, to the $o k k \bar{e}$ cascade, and then to collaboratively finding the next destination.

The phenomenon of $o k k \bar{e}$ cascades as described above is similar in many ways to how okay tokens function in English telephone pre-closings. As described in chapter 2.1, a similar phenomenon occurs in English telephone conversations as the two participants of a conversation say okay to each other multiple times in preparation for closing their conversation. In these cases, each member of the conversation says okay to confirm that they have nothing more to add to the current talk, allowing for a closing to happen unproblematically (Schegloff \& Sacks, 1973). This concept can be applied to transitions within the AR game as well: it's possible that during okke cascades the group members say okke repetitively to signal that they have nothing more to contribute to the answer that is being input for the prompt, allowing for a transition to the next activity to happen unproblematically, and without any member of the group being left behind in the process. The repetitive $o k k \bar{e}$ tokens are opportunity spaces where the participants have chances to move out of or delay the transition; for example, by raising objections to the text that was entered or by adding additional information, or to address procedural and technical issues related to the AR game (Button, 1987). Excerpt (34) shows such an instance: Group 2 finishes entering a response to the location 1 prompt, goes through an okke cascade, but begins a troubleshooting sequence instead of trying to find the next location.

(34) [JAPESLSep072016RC2.1:09:20]
01
( 0 enters response to location 1 prompt))
$02 \mathrm{~S}$ : iinjanai ka 
that's fine, isn't it?

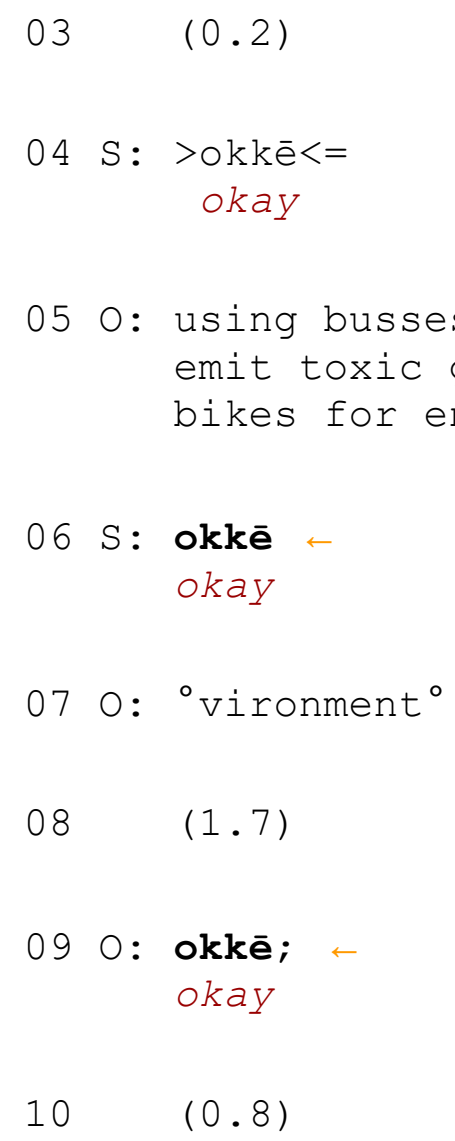

11 Y: okkē:

okay

12 s: save

$13(5.0)$

$14 \mathrm{~S}:>\mathbf{o k k} \overline{\mathbf{e}}<$

okay

$15 \quad(0.6)$

16 s: a' sō ka (kore nōto) janē?

oh is that right? isn't (this the note) 
18 S: nōto wan ja [nēka

isn't this note one?

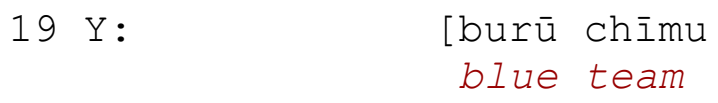

$20 \quad(0.3)$

21 o: mā atteru ka dō ka wakannai

well I have no idea if it's right or not

O reads aloud the entirety of the group's collaboratively formulated response to the prompt on line 05 , and then the group follows up with an okke cascade that spans from line 06 to line 14 . Then, instead of transitioning to finding the next location, $\mathrm{S}$ indicates on line 16 that he is having technical issues with the AR game by saying $a^{\prime} s \bar{o}$ ka (kore nōto) janē? (oh is that right? isn't this the note). Following S's indication of trouble, the other group members follow S's lead and participate in the troubleshooting session. Y looks at the iPhone screen and says burū chimm (blue team), perhaps reading text from a note left by another group that had previously played the game. Then $\mathrm{O}$ also looks at the iPhone screen and says mà atteru $k a d \bar{o} k a$ wakannai (well I have no idea if it's right or not), indicating that he doesn't know how to resolve the situation. This instance suggests that $o k k \bar{e}$ cascades are potentially opportunity spaces where group members can mutually postpone a transition to the next stage of an activity by indicating that there is some obstacle to progressing to the next stage of the activity, and then collaboratively engage in an effort to resolve the problem. 
Although, as described above, okkē cascades have similarities to how repetitive okay tokens are used in English telephone conversation pre-closings, there are also several aspects of $o k k \bar{e}$ cascades that differ from the English language phenomenon described by Schegloff \& Sacks (1973) and Button (1987). There are 3 main differences between the two phenomena: (1) Okkē cascades occur during face-to-face interaction and not telephone conversations; in fact, okkē tokens are generally not used in the preclosings or closings of Japanese phone conversations. (2) Instead of the leading to the end of a conversation, okke cascades lead toward continuing cooperative activity, which often results in highly coordinated actions between the group members. (3) Rather than just occurring between two people, okke cascades can occur between groups of more than 2 participants. These differing characteristics suggest that okkē cascades cannot be strictly explained in terms of opportunity spaces for moving out of transitions. One aspect of okke tokens that needs to be taken into consideration is that the tokens in an okke cascade can also be considered assessments. As described in section 4.4, a turn consisting of a single $o k k \bar{e}$ token can be treated as an unproblematic assessment by Japanese speakers. In an $o k k \bar{e}$ cascade, this can lead to group consensus that the answer to the prompt is unproblematic, and thus the group is ready to transition to the next part of the activity. Therefore, okke cascades may be a method for groups of Japanese speakers to coordinate their actions and encourage group consensus during activities that require cooperation. Research by Watanabe (2005) on the differences between American and Japanese group discussions suggests that Japanese native speakers tend to be highly attentive to procedural matters in group contexts; usually coming to a group consensus about the way 
in which a task is carried out before the task is actually executed. Okke cascades may very well be an extension of this behavior, and serve as a means of procedural maintenance throughout an activity. $O k k \bar{e}$ cascades could give group members an opportunity to reconvene at pivotal points during an activity and confirm that all members are 'on the same page' in terms of the progression of the activity. In the same vein, $o k k \bar{e}$ cascades can be used by members of a group to display and reaffirm to each other that they are working as a participation unit called a with (Goffman, 1971). Members of a with perceive each other as moving and acting together, and have the advantage of being able to initiate conversation with each other more easily than with those not perceived to be in the same with. The coordinated reaffirmation of the with that is performed through the $o k k \bar{e}$ cascade may be more necessary in Japanese than in English because the former uses markedly fewer anaphoric references in talk. Therefore, the $o k k \bar{e}$ cascade is a tool that aids in establishing and maintaining group intersubjectivity, specifically in the management of procedural matters and maintenance of the participation unit known as a with. 


\section{Chapter 5}

\section{Conclusion}

In this thesis, I compared the discourse/pragmatic functions of English okay with its Japanese loanword counterpart, okkē. I did this by utilizing the existing literature on okay used in monologic and dialogic settings to establish a taxonomy of functions that the word is capable of expressing. Based on the existing literature, I found that the following 7 functions can broadly apply to English okay: (1) A marker of transition. (2) A structural marker in monologic speech. (3) A marker of irony. (4) A tag question used to confirm understanding or elicit solidarity. (5) A method of asking for or giving permission. (6) A marker of assessment. (7) A response token. Table 2.1 shows these functions as well as the finer sub-functions of okay. After taking these functions into consideration, I asked the following two questions.

RQ1. Of the discourse/pragmatic functions of English okay described in chapter 2 and listed in table 2.1, which functions are common to both English okay and Japanese $o k k \bar{e} ?$

RQ2. Does Japanese $o k k \bar{e}$ have any discourse-pragmatic functions that are different from the established discourse/pragmatic functions of English okay? 
In order to answer these questions, I analysed a spoken corpus of recorded interactions between Japanese native speaker study-abroad students playing an AR game in various locations on the PSU campus. Code-switching between Japanese and English was a common occurrence in the interactions between the participants, so I defined specific criteria to separate occurrences of English okay and Japanese okke. The results of my analysis indicate that the following 4 discourse/pragmatic functions are common to both English okay and Japanese okkē and provide a preliminary answer to RQ1: (1) A marker of transition. (2) A marker of irony. (3) A marker of assessment. (4) A response token. Additionally, there were differences found in the finer sub-functions that $o k k \bar{e}$ is used for; these details are shown in table 5.1 below.

No examples of the following 3 discourse/pragmatic functions were found to be associated with Japanese okke in the corpus: (1) A structural marker in monologic speech. (2) A tag question used to confirm understanding or elicit solidarity. (3) A method of asking for or giving permission. These results suggest that some of the functions found in English okay seem to be present in Japanese okkē as well, but some of them were not found in the data analysed for this thesis. It may very well be that the 3 functions apparently missing from $o k k \bar{e}$ simply do not appear in the corpus due to the very specific task-based nature of activities that are represented in the corpus. Further research on 
spoken language data taken from other settings and contexts such as telephone

conversations, academic lectures, and business meetings is needed to confirm whether or not the permission and monologic functions can apply to Japanese $o k k \bar{e}$ or not. Due to a limited set of words that can be grammatically used as tag questions in Japanese, I

determined that $o k k \bar{e}$ cannot be used as a tag question. However, this is to be expected because it is unusual for a syntactic operator (and the functions associated with it) to be borrowed into another language.

Other than the task-based nature of the interactions recorded within the corpus, another possible reason for the apparently limited functional capacity of okke might be due to the preferred turn construction surrounding okke tokens: the one word okke turn. The majority of turns containing okke tokens within the data tended to contain no other words. This is in contrast to the how turns containing English okay tended to be built: as part of a longer sentence containing many words. It follows that if Japanese $o k k \bar{e}$ tends to appear with less context surrounding it, its apparent functionality may be diminished as a result. This is in addition to the fact that $o k k \bar{e}$ is also more syntactically limited than okay.

Concerning RQ2, my analysis revealed a function of Japanese $o k k \bar{e}$ that does not appear to exist for English okay: the okkē cascade. An okke cascade is when a group of Japanese speakers say $o k k \bar{e}$ in turn (one after another) at a transition point in an activity that requires group consensus or cooperation. Therefore, okke cascades are a sub-function 
of transitional okke. My analysis suggests that Japanese speakers tend to use $o k k \bar{e}$ cascades to maintain group intersubjectivity and to make sure that everybody involved in an ongoing activity is on the 'same page' when a significant development in the activity occurs. The $o k k \bar{e}$ cascade also provides an opportunity space for postponing the transition to the next stage of the activity in case group members need to address technical or procedural issues before continuing.

Additionally, three other noteworthy differences were found between how okay functions and how okke functions. The first of these differences is that the turn structure surrounding okke tends to differ notably from that of okay. Specifically, okke tends to appear more often as the only word within its turn than okay does. This is especially apparent with assessments, where okay almost never appears as the only word within its turn, while $o k k \bar{e}$ tends to appear by itself frequently across all of its functions, including assessments. The second noteworthy difference is that although okke is often used as a response token to acknowledge a completed utterance, it is not used as a continuer to encourage the continuation of an incomplete utterance. The third noteworthy difference is that transitional okke is sometimes used to mark transitions in actions without any surrounding talk. For example, simply the act of coming to a stop after walking a certain distance can potentially be marked by an okkē token. It's not unthinkable that this action- 
to-action marking might also happen with okay, but this phenomenon has yet to be

documented in any research that I know of.

The following table provides a summary of the functions that $o k k \bar{e}$ was found to have in this thesis.

\begin{tabular}{|c|c|c|}
\hline Main Function & Sub-Function & Description \\
\hline \multirow{4}{*}{$\begin{array}{l}\text { Transitional } \\
\text { Okkē }\end{array}$} & $\begin{array}{c}\text { Speech/Action Shift } \\
\text { Marker }\end{array}$ & $\begin{array}{l}\text { Marks transitions between speech and } \\
\text { physical action. }\end{array}$ \\
\hline & $\begin{array}{l}\text { Topic/Action Shift } \\
\text { Marker }\end{array}$ & $\begin{array}{l}\text { Marks transitions between different topics } \\
\text { and actions. }\end{array}$ \\
\hline & $\begin{array}{l}\text { Action/Action Shift } \\
\text { Marker }\end{array}$ & $\begin{array}{l}\text { Marks transitions between different } \\
\text { actions. Can occur independent of } \\
\text { surrounding talk. }\end{array}$ \\
\hline & Okkē Cascade & $\begin{array}{l}\text { Marks transition points in activities that } \\
\text { require group consensus or cooperation. }\end{array}$ \\
\hline $\begin{array}{l}\text { Ironic/Sarcastic } \\
\text { Okke }\end{array}$ & N/A & $\begin{array}{l}\text { Shows contempt or feigns } \\
\text { surprise/deference in response to a } \\
\text { statement, action, or situation that is } \\
\text { perceived as foolish, offensive, or } \\
\text { otherwise worthy of derision. }\end{array}$ \\
\hline $\begin{array}{l}\text { Assessment } \\
\text { Okkē }\end{array}$ & $\begin{array}{l}\text { Standalone } \\
\text { Assessment }\end{array}$ & $\begin{array}{l}\text { Assesses something as fine/unproblematic. } \\
\text { Often appears as the only utterance within } \\
\text { a turn. }\end{array}$ \\
\hline $\begin{array}{c}\text { Response Token } \\
\text { Okke }\end{array}$ & $\begin{array}{l}\text { Acknowledgement } \\
\text { Token }\end{array}$ & $\begin{array}{l}\text { Acknowledges unproblematic receipt of a } \\
\text { previous utterance. Not used as a } \\
\text { continuer. }\end{array}$ \\
\hline
\end{tabular}

Table 5.1: The Discourse/Pragmatic Functions of Okkē 
As mentioned previously, there are a few limitations to the current study. The findings for RQ1 are not conclusive because the data used for this study contain language use from only a single context with a limited set of participants. The findings may very well hold true for Japanese college students playing an AR game on a university campus in the USA, but it is not yet known exactly how okke is used by different types of speakers in other contexts and settings. Likewise, this limitation applies to RQ2 as well; besides group AR games, we don't yet know for sure what other types of group activities elicit $o k k \bar{e}$ cascades. Additionally, the mixed English/Japanese nature of the language found in the data also poses a significant challenge. Although I set criteria for determining what counts as an English okay and what counts as a Japanese $o k k \bar{e}$, a data set with less ambiguity would be preferable for future research in this subject. Using a set of Japanese-language only data to discover whether or not $o k k \bar{e}$ cascades occur in Japanese-only linguistic environments and examining larger group sizes to explore how okke cascades are used in these groups would be two potential lines of research to pursue on this topic in the future.

The findings in this study can potentially be put to use in teaching foreign languages. When teaching Japanese to English speakers, instructors often rely on English-origin loanwords as a way of building large quantities of vocabulary quickly and easily early in their curricula. Although this is a good way of introducing familiar 
vocabulary items, some level of caution should be used by the instructor to ensure that students understand differences in function, meaning, and connotation that may have developed as a result of the shift from English to Japanese. This is where the results of the study can be utilized. Based on the research in this thesis, English-speaking students of Japanese can be taught fairly early on that it's sometimes okay to use $o k k \bar{e}$ when speaking Japanese, and in some cases, such as transition points in casual group activities, it's actually good to use it frequently. Likewise, when teaching English to Japanese speakers, learners can be taught that okay is more syntactically and functionally diverse than $o k k \bar{e}$, and thus can be used in some situations where okkē normally wouldn't be.

In terms of its contributions to linguistics, this thesis adds to the scholarship on comparative pragmatics in general, and more specifically to research on group organization in Japanese conversation. Previous contributions to this field include Aoki (2010) and Watanabe (2005). Aoki (2010), for example, compares rapport management techniques used in task based group talk between Japanese speakers and Thai speakers. He finds that Japanese speakers tend to prefer communal topics, tend to minimize the importance of the self, and frequently use softeners, while Thai speakers tend to prefer individual-oriented topics, tend to capitalize on the self, and frequently use intensifiers. Watanabe (2005), on the other hand, compares framing techniques used in group discussions between Japanese and American English speakers, and finds that the Japanese 
speakers tend to be more methodical about procedural matters, frame reasoning in terms of storytelling sequences, and tend to give multiple accounts during argumentation. Meanwhile, American English speakers tend to be more spontaneous, frame reasoning in terms of briefings, and give single accounts during argumentation. This thesis takes on a more narrow focus than the aforementioned studies by attempting to discern the differences between how a single word and its loanword counterpart are used between speakers of two languages. The results of this thesis can potentially be applied to future studies that analyse Japanese group interaction; particularly studies that focus on analysing language use in task-oriented settings. 


\section{References}

Aizawa, Y., 1985. Intensification by so-called “choked sounds"-long consonants_-in Japanese. In The Phonetic Society of Japan (Ed.), The Study of Sounds, vol. 21, pp. $313-324$

Alim, S. (2004). You know my steez: An ethnographic and sociolinguistic study of styleshifting in a Black American speech community. Durham, North Carolina: Duke University Press for the American Dialect Society.

Aoki, A. (2010). Rapport management in Thai and Japanese social talk during group discussions. Pragmatics, 20(3), 289-313.

Arakawa, S. (1967). Kadokawa gairaigo jiten. Kadokawa shoten.

Atkinson, J., \& Heritage, J. (1984). Structures of social action: Studies in conversation analysis (Studies in emotion and social interaction). Cambridge: Cambridge University Press

Bangerter, A., \& Clark, H. (2003). Navigating joint projects with dialogue. Cognitive Science, 27(2), 195-225.

Barske, T. (2009). Same token, different actions. Journal of Business Communication, 46(1), 120-149. 
Beach, W. A. (1993). Transitional regularities for 'casual' "Okay" usages. Journal of Pragmatics, 19(4), 325-352.

Beach, W. A. (1995) Conversation analysis: "Okay" as a clue for understanding consequentiality. In S. J. Sigman. (Ed.), The consequentiality of communication (pp. 121-162). London: Routledge.

Biber, D., Conrad, S., \& Leech, G. (2002). Longman student grammar of spoken and written English. Harlow, Essex: Longman.

Boersma, P., \& Weenink, D. (2020). Praat: doing phonetics by computer [Computer program]. Version 6.1.20beta, retrieved 10 September 2020 from http://www.praat.org/

Bruch, J., 1986. Expressive phonemes in Japanese. Kansas Working Papers in Linguistics $11,1-8$

Button, G. (1987). Moving out of closings. In: G. Button \& J. R. E. Lee (Eds.), Intercommunication series, vol. 1: Talk and social organisation (pp. 101-151). Clevedon, England: Multilingual Matters.

Cassidy, F. (1981). OK. Is it African? American Speech, 56(4), 269-273.

Clift, R. (1999). Irony in conversation. Language in Society, 28(4), 523-553. 
Condon, S. (2001). Discourse ok revisited: Default organization in verbal interaction. Journal of Pragmatics, 33(4), 491-513.

Couper-Kuhlen, E., \& Ford, Cecilia E. (2004). Sound patterns in interaction: Crosslinguistic studies from conversation. Amsterdam; Philadelphia: J. Benjamins Pub.

Filipi, A., \& Wales, R. (2003). Differential uses of okay, right, and alright, and their function in signaling perspective shift or maintenance in a map task. Semiotica 147(4), 429-455.

Frellesvig, B. (2011). A history of the Japanese language. Cambridge, New York: Cambridge University Press.

Furukawa, C. (2014). A Study of small talk among males : Comparing the U.S. and Japan. [Master's thesis, Portland State University]. PDXScholar.

Gaines, P. (2011). The multifunctionality of discourse operator okay: Evidence from a police interview. Journal of Pragmatics, 43(14), 3291-3315.

Gardner, R. (2001). When listeners talk: Response tokens and listener stance. Amsterdam/Philadelphia: John Benjamins Publishing Company.

Goffman, E. (1971). Relations in public; microstudies of the public order. Basic Books.

Gottlieb, N. (2005). Language and society in Japan (Contemporary Japanese society). New York, N.Y.: Cambridge University Press. 
Gravano, A., Hirschberg, J., \& Benus, S. (2012). Affirmative cue words in task-oriented dialogue. Computational Linguistics, 38(1), 1-39.

Guthrie, A. (1997). On the systematic deployment of okay and mmhmm in academic advising sessions. International Pragmatics Association, 7(3), 397-415.

Heisler, T. (1996). OK- A dynamic discourse marker in Montreal French . In J. Arnold, R. Blake, B. Davidson, S. Schwenter, \& J. Solomon (Eds.), Sociolinguistic variation: Data, theory, and analysis. Stanford, California: Center for the Study of Language and Information.

Hellermann, J. Thorne, S. L., \& Fodor, P. (2017). Mobile reading as social and embodied practice. Classroom Discourse, 8(2), 99-121.

Heritage, J. (1984). A change-of-state token and aspects of its sequential placement. In J. Atkinson \& J. Heritage (Eds.), Structures of social action: studies in conversation analysis. Cambridge University Press.

Holmes, J. (1982). The functions of tag questions. English Language Research Journal, $3,40-65$.

Jefferson, G. (1984) Transcript notation. In J.M. Atkinson, \& J. Heritage (Eds.) Structures of social action: Studies in conversation analysis, (pp. ix-xvi). Cambridge: Cambridge University Press.

Johnson, K. (2012). Acoustic and auditory phonetics (Third edition.). Wiley-Blackwell. 
Jones, A. M. (2016). Starts and Stops: Multimodal practices for walking as a group in an augmented reality game. [Master's thesis, Portland State University]. PDXScholar.

Jorden, E., \& Noda, Mari. (1987). Japanese: The spoken language. New Haven: Yale University Press.

Kay, G. (1995). English loanwords in Japanese. World Englishes, 14(1), 67-76.

Kovarsky, D. (1989). On the occurrence of okay in therapy. Child Language Teaching and Therapy, 5(2), 137-145.

Leech, G., Rayson, P., \& Wilson, A. (2001). Word frequencies in written and spoken English: Based on the British National Corpus. Harlow: Longman.

Levin, H., \& Gray, D. (1983). The lecturer's OK. American Speech, 58(3), 195-200.

Maynard, D., Freese, J., \& Schaeffer, N. (2010). Calling for participation: Requests, blocking moves, and rational (inter)action in survey introductions. American Sociological Review, 75(5), 791-814.

Merritt, M. (1978). On the use of "O.K." in service encounters. Working Papers in Sociolinguistics, 42(1), 4-22.

Metcalf, A. (2010). OK the improbable story of America's greatest word. Oxford; New York: Oxford University Press. 
Mirivel, J. \& Tracy, C. (2005). Premeeting talk: An organizationally crucial form of talk. Research on Language and Social Interaction, 38(1), 1-34.

Müller, F. (1996). Affiliating and disaffiliating with continuers: Prosodic aspects of recipiency. In E. Couper-Kuhlen \& M. Selting (Eds.), Prosody in conversation: interactional studies. Cambridge University Press.

Othman, Zarina. (2010). The use of okay, right and yeah in academic lectures by native speaker lecturers: Their 'anticipated' and 'real' meanings. Discourse Studies, 12(5), $665-681$.

Pillet-Shore, D. (2003). Doing "Okay": On the multiple metrics of an assessment. Research on Language \& Social Interaction, 36(3), 285-319.

Pomerantz, A. (1984). Agreeing and disagreeing with assessments: Some features of preferred/dispreferred turn shapes. In J. M. Atkinson, J. Heritage (Eds.), Structures of social action (pp. 57-101). Cambridge, Cambridge University Press.

Read, A. (1963a). The first stage in the history of "O. K.". American Speech, 38(1), 5-27.

Rendle-Short, J. (1999). When "okay" is okay in computer science seminar talk. Australian Review of Applied Linguistics, 22 (2), 19-33.

Rockwell, P. (2007). Vocal Features of Conversational Sarcasm: A Comparison of Methods. Journal of Psycholinguistic Research, 36(5), 361-369. 
Schegloff, E., \& Sacks, H. (1973). Opening up closings. Semiotica, 8(4), 289-327.

Schegloff, E. (1982). Discourse as an interactional achievement: Some uses of 'uh huh' and other things that come between sentences. In: D. Tannen (Ed.), Analyzing discourse: Text and talk (pp. 71-93). Georgetown University Press: Washington D.C.

Schegloff, E. (1986). The routine as achievement. Human Studies, 9(2), 111-151.

Schiffrin, D. (2001). Discourse markers: Language, meaning, and context. In D. Schiffrin, D. Tannen, \& H. Hamilton (Eds.), The handbook of discourse analysis. Malden, MA: Blackwell.

Schleef, E. (2008). The "lecturer's OK” revisited: changing discourse conventions and the influence of academic division. American Speech, 83 (1), 62-84

Simpson, R., Briggs, S., Ovens, J., \& Swales, J. (2000) The Michigan corpus of academic spoken English. Ann Arbor: Regents of the Univ. of Michigan. http://lw.lsa.umich.edu/eli/micase/index.htm.

Speer, S., \& Stokoe, E. (2012). Ethics in action: Consent-gaining interactions and implications for research practice. British Journal of Social Psychology, 53(1), 54-73.

Tamori, I., 1991. Nihongo Onomatope-no Kenkyuu [Research on Japanese Onomatopoetic Words]. Kobe Shoka Daigaku Keizai Kenkyuujo, Kobe. 
Thorne, S. L., Hellermann, J., Lester, D., \& Jones, A. (2015). Interactional practices and artifact orientation in mobile augmented reality game play. PsychNology, 13(23), 259-286.

Turner, K. (1999). Functional variation of okay/alright in spoken discourse (MA Special Project). UNSW, Sydney, Australia.

Van Zyl, M., \& Hanekom, J. J. (2013). When "okay" is not okay: Acoustic characteristics of single-word prosody conveying reluctance. The Journal of the Acoustical Society of America, 133(1), EL13-EL19

Watanabe, Suwako. (2005). Cultural Differences in Framing: American and Japanese Group Discussions. In S. F. Kiesling \& C. B. Paulston, Intercultural Discourse and Communication (pp. 226-247). Blackwell Publishing Ltd.

Yngve, V. (1970). On getting a word in edgewise. Papers from the 6th Regional Meeting, Chicago Linguistics Society, April 16-18. Chicago: Chicago Linguistics Society. 
Appendix A: English and Japanese AR Game Texts

Greeting:

Hello Agent. I am an artificial intelligence from the future. You have traveled back in time, from the year 2070 to the present. The environment of our planet is dying and we need your help. Will you help save the future?

ごきげんよう、諸君。私は未来から来た人工知能だ。君たちは、2070 年の世界から時間を超 えてやってきた。我々の惑星は今、滅亡しかけている。お願いだ！助けてくれ！未来を救う旅 に出てくれるか?

Closing:

Great! Your goal is to explore the Portland State University campus and find 5 examples of "green" technology in the year 2016. You will find sites of interest marked on your map. You will need to record information about the current technology that is used at PSU. I will then send this information to the agents who are living in the year 2070. よかった！君たちのミッションはポートランド州立大学のキャンパスを調査し、2 016 年の「グ リーン」テクノロジーを 5 つ発見すること。目印は地図上に表示されている。君たちは、PSUで 現在使われている技術の情報を記録する必要がある。君たちが見つけたその情報は、私が 2070 年のエージエントヘと送信する。

Plaque: How to start the game

All the buttons you will need to play are located at the bottom of the screen. As you explore the campus, things will begin to show up on your map. Walk towards them! Your first stop is under the skybridge between the Smith Memorial Student Union and Neuberger Hall.

操作ボ夕ンは画面の下にあるから、よく確認しておくように。調査場所は地図上に表示される。 その目印に向かって歩いてくれ。まず初めのステップとして、Smith Memorial Student Union と Neuberger Hall の間にあるスカイブリッジに行ってもらおうか。

Location 1: Neuberger Hall Bike Parking

Neuberger Hall Bike Parking

There are more than 25 bike parking areas on the PSU campus. ***What are some of the advantages or disadvantages of riding a bike to school?*** Record your answer by creating a text, audio, or video note within the game's notebook. Name the note "Note 1".

Neuberger Hall 自転車置き場

PSU のキャンパスには2 5 か所もの自転車置き場がある。***通学に自転車を使うことの メリット・デメリットはなんだろうか？****君たちの答えをノート欄にあるツールを使って記録し てくれ。記録の方法は 3 つある。録音や録画、または画面に直接入力してもらっても構わない。

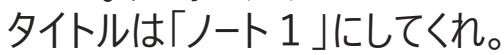

Location 2: Lincoln Hall Solar Array 
The solar panels on the roof of Lincoln Hall supply almost 3\% of this building's energy. $* * *$ What are some of the advantages or disadvantages of using solar energy?*** Record your answer in the game's notebook. Name the note "Note 2".

Lincoln Hall の屋根に取り付けてあるソーラーパネルから、ビルのエネルギーの約 $3 \%$ ～供給さ れている。***ソーラーパネルを使うことのメリット・デメリットは何だろうか ? 君たちの答えを ノート闌にあるツールを使って記録してくれ。タイトルは「ノート 2 」にしてくれ。

Location 3: Construction Site Where Electric Ave Used to Be

Oh my gosh! What happened to 'Electric Avenue'? Isn't this where electric cars used to be charged for free? ${ }^{* * *}$ Is this the dusk of green technology?*** Record your answer in the game's notebook. Name the note "Note 3".

なんてこった！ E l e c t r i c A v e n u e は、一体どうなったんだ?ここは、電気自 動車を無料で充電できる場所だったはずなのに！？***もしかしてこれはグリーンテクノ口 ジーの終わりを告げるのだろうか？***君たちの答えをノート欄にあるツールを使って記録し てくれ。タイトルは「ノート3」にしてくれ。

Location 4: Academic and Student Recreation Center (ASRC)

The toilets in the Academic and Student Recreation Center (ASRC) flush with rainwater collected from the roof. ***What are some other ways that rainwater can be used?*** Record your answer in the game's notebook. Name the note "Note 4".

Academic and Student Recreation Center (ASRC)のトイレの水には、屋根で集めた雨水が 使われている。***雨水の他の利用法はないだろうか？****君たちの答えをノート闌に あるツールを使って記録してくれ。タイトルは「ノート4」にしてくれ。

Location 5: Urban Center Plaza

The Portland Streetcar, two MAX light rail lines, and many buses stop near the Urban Plaza. The Portland Streetcar is free for all PSU students, with your PSU identification card. ***What form of transportation do you use when you travel to school?*** Record your answer in the game's notebook. Name the note "Note 5".

Urban Plaza の近くには、ストリートカーや MAX、そして、たくさんのバス停がある。ストリートカー は、PSUの学生証を持っていれば、学生はみんな無料で乗れる。***君たちは、どんな方 法で通学している? ****君たちの答えをノート欄にあるツールを使って記録してくれ。タイトル

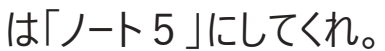

\section{Closing}

You did it! By exploring the green technology at PSU, you have saved the future of our planet.

Thank you for playing. Your everyday actions and awareness of green technologies help to maintain a healthy environment for us all, both now and in the future.

Keep up the good work, Agent!

おめでとう！PSU のグリーンテクノロジー調査によって、私たちの星の未来は救われた！ 
プレイしてくれてありがとう。みんなのすばらしい環境を守るために、現在も未来も、君たちの日 常生活での行動が役に立つのだ。

これからもよろしく、諸君！ 


\section{Appendix B: Transcription Notation}

@example@=Words surrounded by @ symbols represent laughing speech.

${ }^{\circledR}$ example ${ }^{\circledR}=$ Words surrounded by ${ }^{\circledR}$ symbols represent reading aloud.

example $(0.5)$ example $=$ Numbers in parentheses represent a pause in speech measured in seconds.

example (. ) example = A single period in parentheses represents a very short pause between utterances.

example? = A question mark at the end of an utterance represents rising intonation.

example; $=$ A semicolon at the end of an utterance represents slightly rising intonation.

example. = A period at the end of an utterance represents falling intonation.

example, =A comma at the end of an utterance represents incomplete or continuing intonation.

example: = A colon represents a prolonged sound. Multiple colons indicate an even longer sound.

$>$ example $<=$ Words surrounded by angle brackets pointing inwards represent rapid speech.

$<$ example $>=$ Words surrounded by angle brackets pointing outwards represent slow speech.

$($ example $)=$ Words in parentheses are uncertain transcriptions. 
(example/egg sample) = Words within parentheses separated by a slash indicate an uncertain transcription, with two alternatives as to what was being said.

( ) = Empty parentheses indicate inaudible or incomprehensible speech.

$(($ example $))=$ Transcriber's notes. These often consist of descriptions of the participants' physical movements.

exa [mple

[example $=$ The left bracket indicates the start of overlapping speech. This overlap bracket is sometimes represented by the full-width $\lceil$ bracket in appendix $\mathrm{C}$.

rei

example $=$ Text in dark red italics is an English translation of the above Japanese transcript.

example $\leftarrow=$ Arrows pointing left at bold text indicate areas of the transcript that are especially relevant to the current discussion and analysis.

$\uparrow$ example $\uparrow=$ Words surrounded by arrows pointing upwards represent higher pitched than normal speech.

${ }^{\circ}$ example $e^{\circ}=$ Words surrounded by degree symbols represent quiet speech.

Jexample.J $=$ Words surrounded by beamed notes represent a singing voice

\$example\$ $=$ Words surrounded by dollar symbols represent a smile voice. 
$\mathrm{E}$ ?: = A question mark after a speaker's name indicates that the transcriber is unsure of the identity of the speaker. A question mark by itself in this position indicates that the transcriber cannot make a guess as to the speaker's identity.

example= =example $=$ Two lines of speech connected by an equals symbol indicates latched speech. No pause between vocalizations.

examp- $=$ Utterances ending with a dash symbol indicate cut-off speech.

\# example\# = Words surrounded by pound symbols represent utterances spoken in creaky voice.

$>>$ example $<<=$ Words with doubled symbols around them indicate a more extreme version of one of the above conventions. Double inwards facing angle brackets, for example, indicate very rapid speech. 


\section{Appendix C: Transcripts of the AR Game}

These transcripts correspond to files created at the time of the recording, named in square brackets in this appendix. Short descriptions of the contents of each file follow each file name. Portions of the transcript that are used in this thesis are highlighted in grey and labeled with transcribers notes. The transcripts in this appendix are not as detailed as the excerpts used in the body of the thesis. The transcripts shown in this section were reworked to reflect the video and audio data in greater detail in the body of the thesis. Gestures and movements, for example, are often not noted in the following transcripts, but are noted in the body of the thesis. The following section shows transcripts from groups 1, 2, and 3. It is not a representation of all of the transcriptions that were made of the AR game, but it is a representation of all of the transcripts that were analysed and discussed for this thesis.

\section{[JAPESLSep072016HC4,1]}

This file was not transcribed because it was recorded in a large crowd while the camera and microphone were still being set-up. This resulted in a mostly inaudible and incomprehensible file. The participants had not started playing the AR game yet at this point.

\section{[JAPESLSep072016HC4,2]}

The groups are all still gathered in front of the library and are still trying to get the AR game installed and started at this point.

A ?：俺は：： :

(1. 1 )

A ? : > 映画観てた サマーウオーズ観てた $<=$

（（サマーウオーズは日本のアニメ映画））

$\mathrm{M}$ : =あ：：：ああ：：（）>何で携帯入ってんの< (0.8)

A ? : 入れたから

(0.8)

$\mathrm{M}$ ：＞レベル高けえな<

(0.8)

A ： アップロードをねダウンリ - （．）ローディングした（らね）

(6.9)

M : > (ちょ) 今自分まじでどうなっているか（，６）気になるんだけどく 
(2. 2 )

M：（）あんたの携帯あんじやない（0４）そうそん時は

(3. 3)

A : (待って みたいだ)

$(0.4)$

M：>ねえ（ど）糞だせえな やっぱこれ（0．8）思った@通り@<

(9.9)

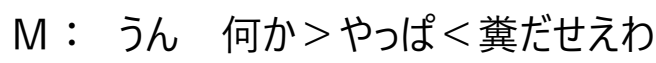

(4.2)

$M ：$ 髪がボサボサになるじやねえ゙か゚

(0.2)

C: ah hah hah ah hah ah [hah:

$\mathrm{M}$ :

(0.3)

C : ${ }^{\circ}$ a hah ${ }^{\circ}$ 女「子

A ? : 「かわいい: : : : か : : : わいい: : : :「:

C ? : [女子か

(0. 6)

A？：あれ ふてくされちやったの

M : huh huh うるせ : (0．3） heh 〈そ 普通にうぜ：：.h [heh

A ? :

い（.）はい?

( 0.7 )

C : ねえ そんな画面出ないんだけど

(0.2)

$\mathrm{H}$ ？：ああ（下）

(6. 0$)$

A：（ああもう）壞れてる「のかも

$\mathrm{H}$ : $\quad$ 「ああ：（0，2） wifi あれなんだよ

(1. 4)

$H$ : you must $(0.3){ }^{\circ}$ use this one ${ }^{\circ}$

$(0.8)$

$\mathrm{M}:$ え

$(0.5)$

C : う^そ: : :

$\mathrm{H}$ ? : ‘あ： :

$M ： 4 G$ じや駄目なの？

(1.2) 


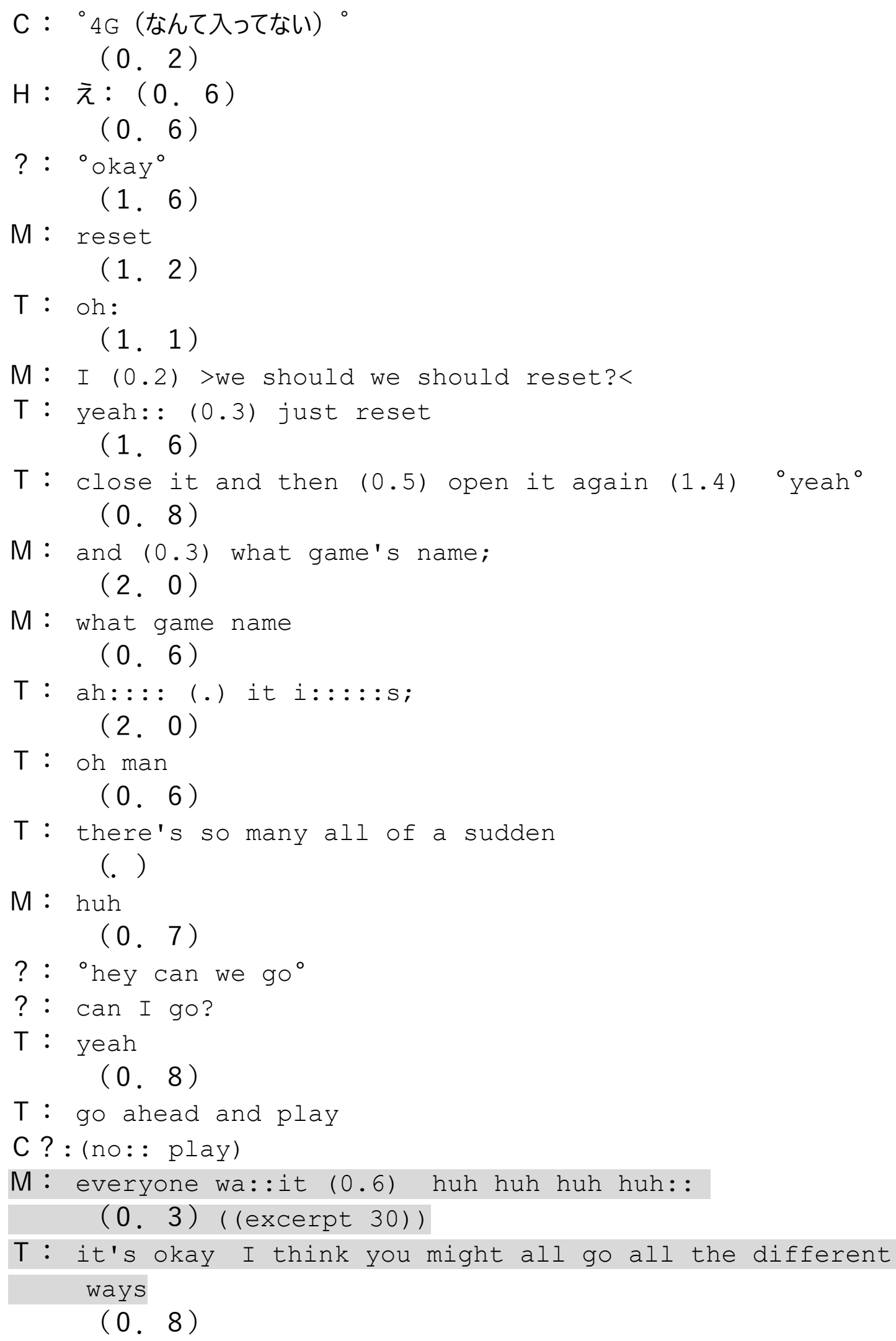




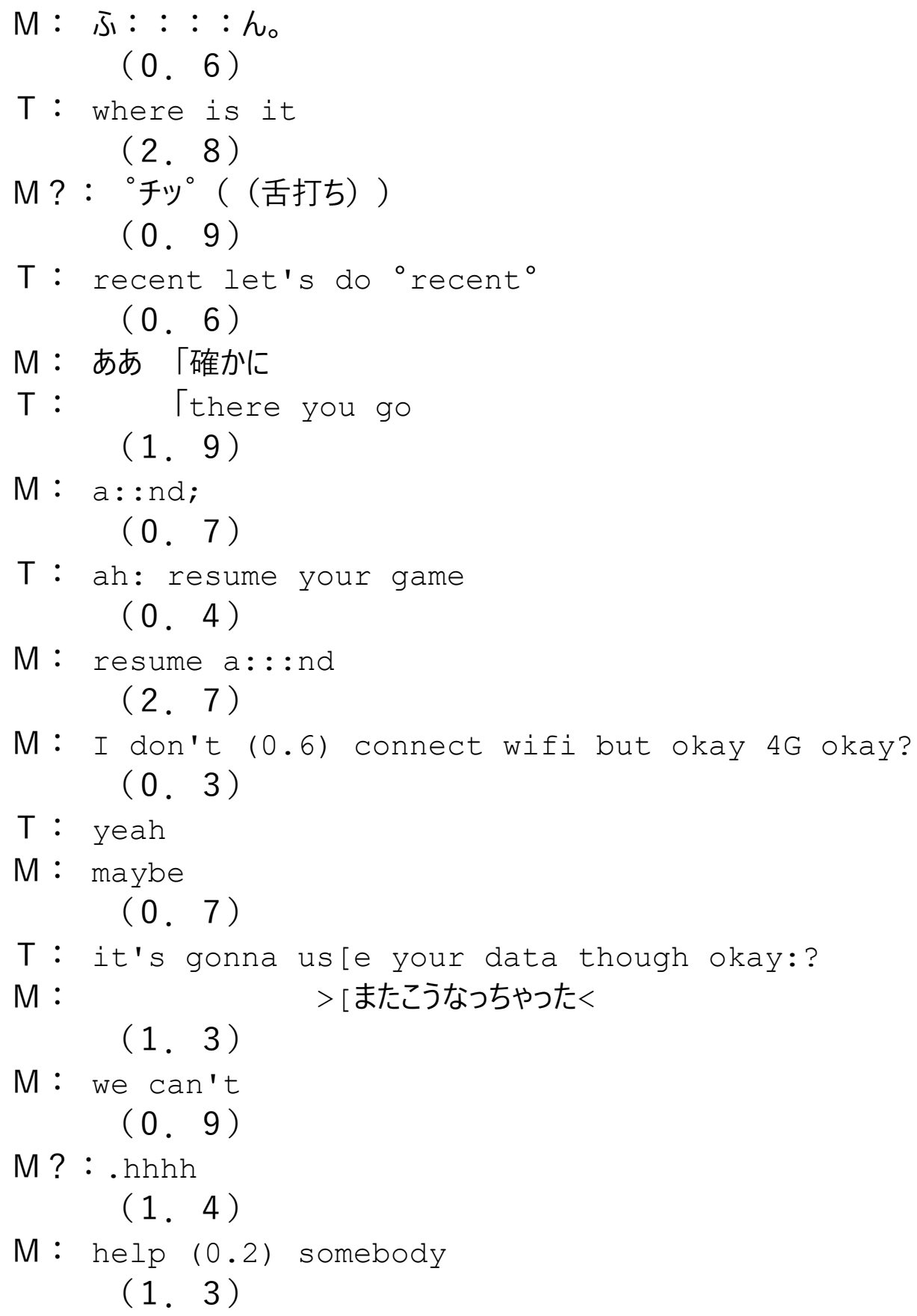


(1. 4)

T: I can walk with them

(. )

T 2 : okay

T: I just won't say anything

T 2 : yes sure sure

(0.5)

C ? : ${ }^{\circ}$ え ${ }^{\circ}$

( 0.3$)$

M：これ何（「使ったらしい）ヴ（０．5）何でだろう

T: $\quad$ I thought I had Aris on here (.) where did I put Aris on here?

(1. 0 )

C ? :えっ>全部消しちやったく「遅いから

T? : $\quad$ Tah there's Aris (I'm just gonna)

(1.9)

T : okay we can use my phone[I just gotta download the app first

M :

[uh huh

(1. 6)

M : why my (0.4) [phone can't

$\mathrm{T}:$

(0.3)

T : huh huh hah

(0.4)

$M: h:[m::::$ :

T: [ah: that's okay (1.1) \#don't worry about it\# (1. 6)

[JAPESLSep072016HC4,3]

The AR game has not yet started at this point.

(5.4)

$M ?:{ }^{\circ}$ おっ

C ? : a : : : : nd

(4. 0$)$

$\mathrm{T}:{ }^{\circ} \mathrm{oh}$ shoot (

)$^{\circ}$

(2. 7 ) 
T: do I need to have an ID?

( 1.0$)$

$\mathrm{T}:($ to $\log i n ;)$

$(0.2)$

$\mathrm{T} 2: \mathrm{u}::::: \mathrm{m}$

$\mathrm{M}:$ うん>「やっぱりできねえわく

T2 2 ( ) yeah you can you can either make one?

(0.3) [uh:: : the: : make an account or you've already got one.

T: $\quad{ }^{\circ}\left[()^{\circ}\right.$

T 2 : then yeah that would \# (where you're looking)\# ( 0.3 )

$\mathrm{T}:{ }^{\circ} \mathrm{okay}^{\circ}$

$\left(\begin{array}{ll}1 & 0.5\end{array}\right)$

$\mathrm{T}$ : almost there guys, sorry you get a late start but that's okay,

M : uh huh;

(3. 0 )

T: you're gonna be the best team \#anyway\#, (1.5)

C : ‘あああ ${ }^{\circ}$

(2.3)

$\mathrm{T}:{ }^{\circ}$ oh jeez ${ }^{\circ}$

(2.3)

T: ${ }^{\circ}$ hah hah [ (

M : $\quad$ [huh hah hah hah hah hah hah

T? : >huh hah hah hah hah=<

$\mathrm{M}:=$ no no

(0. 2)

T? : ${ }^{\circ}$ huh $^{\circ}$

( 3.7 )

M : 何で俺の使えないんだろ

T ? : ${ }^{\circ}$ (>ah hah hah</uh huh) ${ }^{\circ}$

M : why (0.2) my phone can't

(1.4)

C ? : ${ }^{\circ}(\text { ね })^{\circ}$

( 0.3 )

M : accept my phone 


\section{(2. 4)}

T : okay

(1. 3 )

T: (new guy) Chrono Ops (1.0) Japane: : : ${ }^{\circ}$ se: ${ }^{\circ}$

(4.6)

$M$ : `わあ >本当だく

$\mathrm{T}:$ : [kay?

C: [oh thank you

M ? : ${ }^{\circ}\left([\quad)^{\circ}\right.$

T: there you go (.) now you (guys: [ )

M : [it's okay? it's yours

\section{( 0.4$)$}

T: yes my phone but it's okay just don't drop it (0.2) huh hah hah hah: hah

C: ${ }^{\circ}$ okay ${ }^{\circ}$ [.hh $\left({ }^{\circ}\right.$ thank $\left.{ }^{\circ}\right)$ you: :

M : [okay?

T: yeah (0.3) I might walk (0.3) with you but [I wontI'm not =

M :

[@okay@

=allowed to say anything=

M: =huh hah hah

(1. 4)

C : ${ }^{\circ} \circ{ }^{\circ}$

( 13.2 )

M : where

(0. 2)

$C$ : where will we ${ }^{\circ} 0^{\circ}$

( 0.6 )

T: make sure you hit start

(0.6)

$\mathrm{M}:{ }^{\circ}$ hit start $^{\circ}$

C : ouh huh ${ }^{\circ}$

( 0.3 )

T: ${ }^{\circ}$ and then (it'll tell) you what to do ( 0.3$)$

C: ${ }^{\circ}$ uh huh; ${ }^{\circ}$

T: [\#there you go\#

$M ?:\left[\begin{array}{ll}( & )\end{array}\right.$ 
(2. 6)

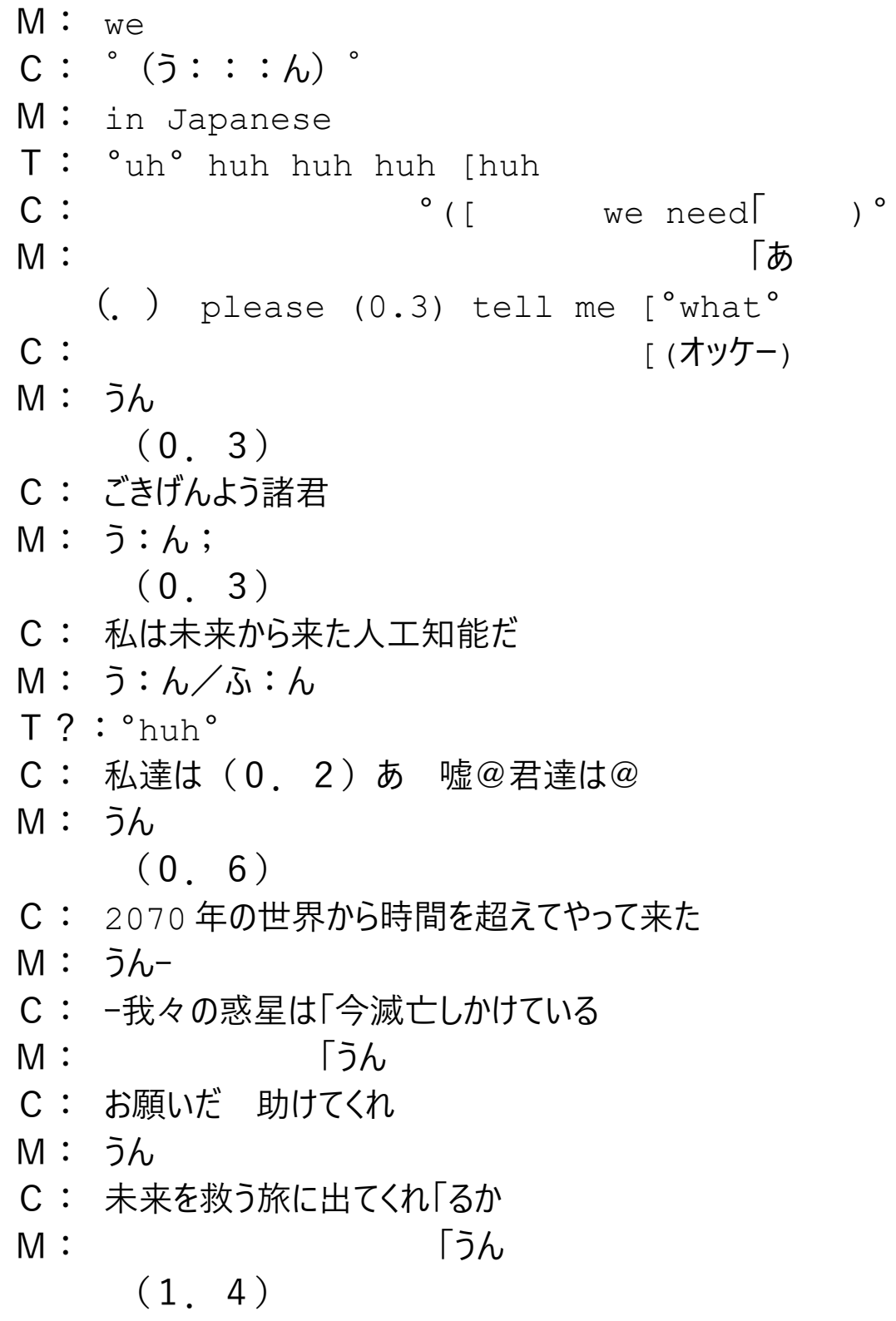

C ： 良かった 君達のミッションはポートランド州「立大学のキャンパスを調 査し 20 「16 年の

$\mathrm{M}$ :

「うん

\section{「うん}

C ：グリーンテクノロジーを五つ発-（０．5）＜発＞見すること

$\mathrm{M}:$ j

( 0.5$)$

C：目印は地図上に指示されている

$M: j h$ 
C：君達は P：：：：：SUで

$M:$ j

C ： 現在使われている技術の

$\mathrm{M}:$ : う

C： 情報を記録する必要がある

$\mathrm{M}:$ : う

C : 君達が見つけたその情報を わ「たしが 2070 年のエージェントへと送信 する

$\mathrm{M}:$

「うん

$M: j h$

(1.3)

C : 以上

(0.7)

M: and (0.3) そして a: : : : : :nd (.) go:: : where.

(5. 5)

$M: j h$;

C: ${ }^{\circ} \mathrm{a}::::::: \mathrm{nd}^{\circ}$

(2. 4)

C : here?

( 0.7$)$

C: ${ }^{\circ}$ (which $(0.2)$ we will go; $)^{\circ}$

(1. 1)

T : I don't know: : : : .

C ? : maybe: : ;

M : huh hah hah hah hah

T : ${ }^{\circ}$ heh heh ${ }^{\circ}$ (0.5) .hh

(0.2)

C : ○[あ : : : 。

T: [it's all you

M? : hah hah

\section{[JAPESLSep072016HC4,4]}

At this point group 1 has started to head toward the first location.

(1.0)

C : こっちに（0，6）こっちかなあ；

(2.4)

$\mathrm{M}$ ：ああ：？ 


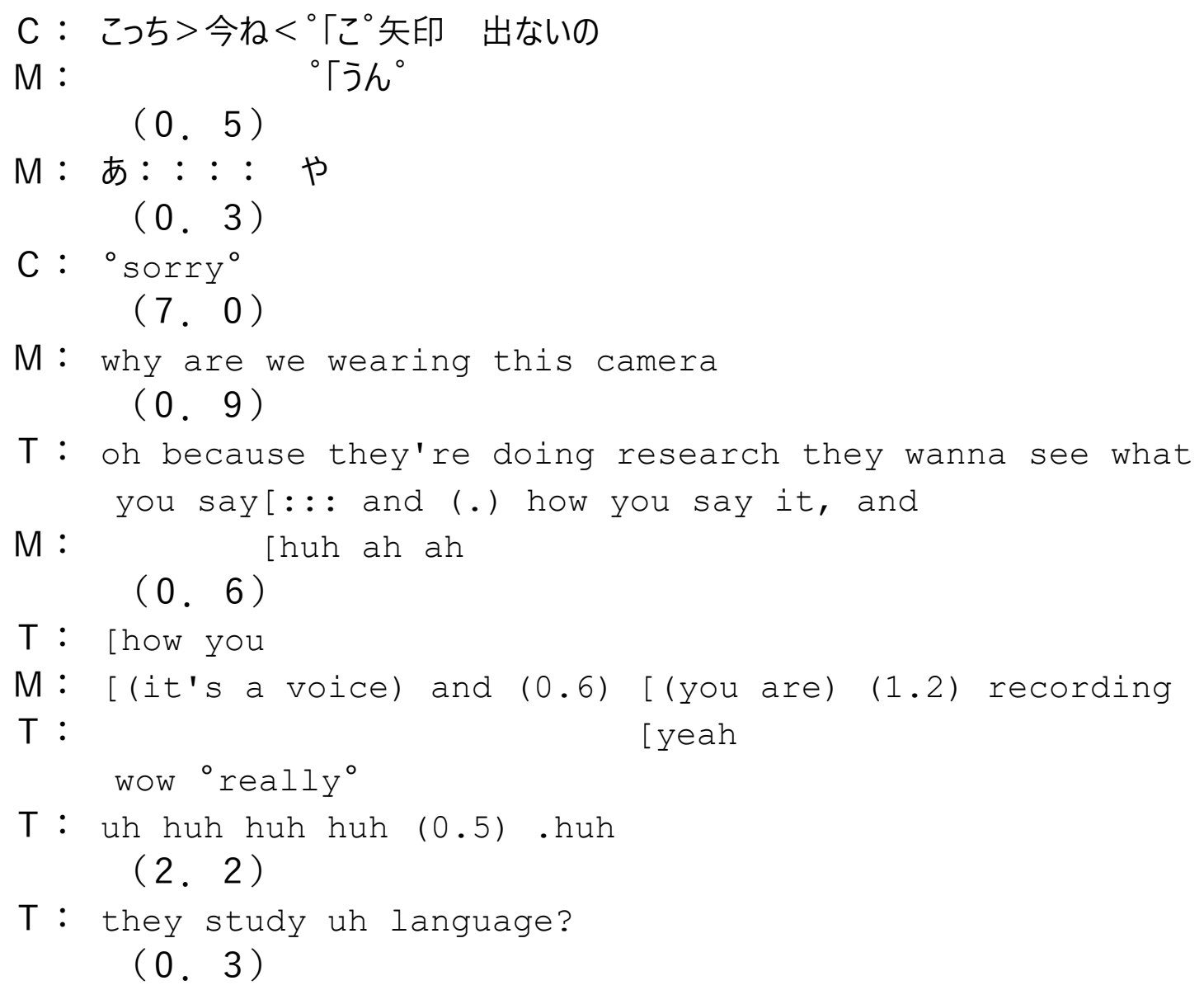

M : uh huh

$$
(0.3)
$$

$\mathrm{T}$ : and how people use langu[age

M : $\quad[a h::::: a h::$ hah hah

$$
\text { ( } 0.4 \text { ) }
$$

$\mathrm{T}$ : and so that's what their- want- they want "\#to find out \#

(1.9)

C : ${ }^{\circ}$ 寒 : : い $^{\circ}$

(1.9)

M : (Nike)

$$
\text { (0.6) }
$$

C : ${ }^{\circ}$ yeah $^{\circ}$

$$
\text { (0.2) }
$$

M: I do not have to (0.3) talk (0.5) a lo[t
$\mathrm{T}:$
[ah heh heh heh: $\cdot \mathrm{hh}$ 
(0. 4)

M: it's camera record my

( 0.5 )

T: eyes [ your (.) everything you saye (0.2) .hh

M : [voice hah (0.3) hah hah

(5. 1)

M: are you okay?

(0.8)

C : yeah

(0.6)

$M$ : uh huh.

$(10.2)$

C : ${ }^{\circ}$ neu ${ }^{\circ}(0.9)$ ber (0.2) ger (0.4) hall 自転車 $(0.5)$ 置き 場

(3. 7)

M : bicycle parking area

(0.6)

C : ${ }^{\circ}$ the ${ }^{\circ}$

M: bike par(senqui) (0.2) parking area $t-$

(4.9)

C ? : ${ }^{\circ}(\text { つぱい })^{\circ}$

(3. 7 )

$M:$ ふ: : : : : h

(8. 7 )

$M:$ rainy da: :::y

(0.5)

T: yeah (0.2) huh huh huh .hh (0.4) I haven't really been on campus much s[o,

M : $\quad[\mathrm{hmmm}$

(0.9)

T ? : ${ }^{\circ}$ (Neuberger) ${ }^{\circ}$

C: near here near here

$M$ : near here near here?

(0. 2)

C: ${ }^{\circ}$ yeah $^{\circ}$

( 0.4 )

$\mathrm{T}$ : ${ }^{\circ}$ near here?

(0. 4) 


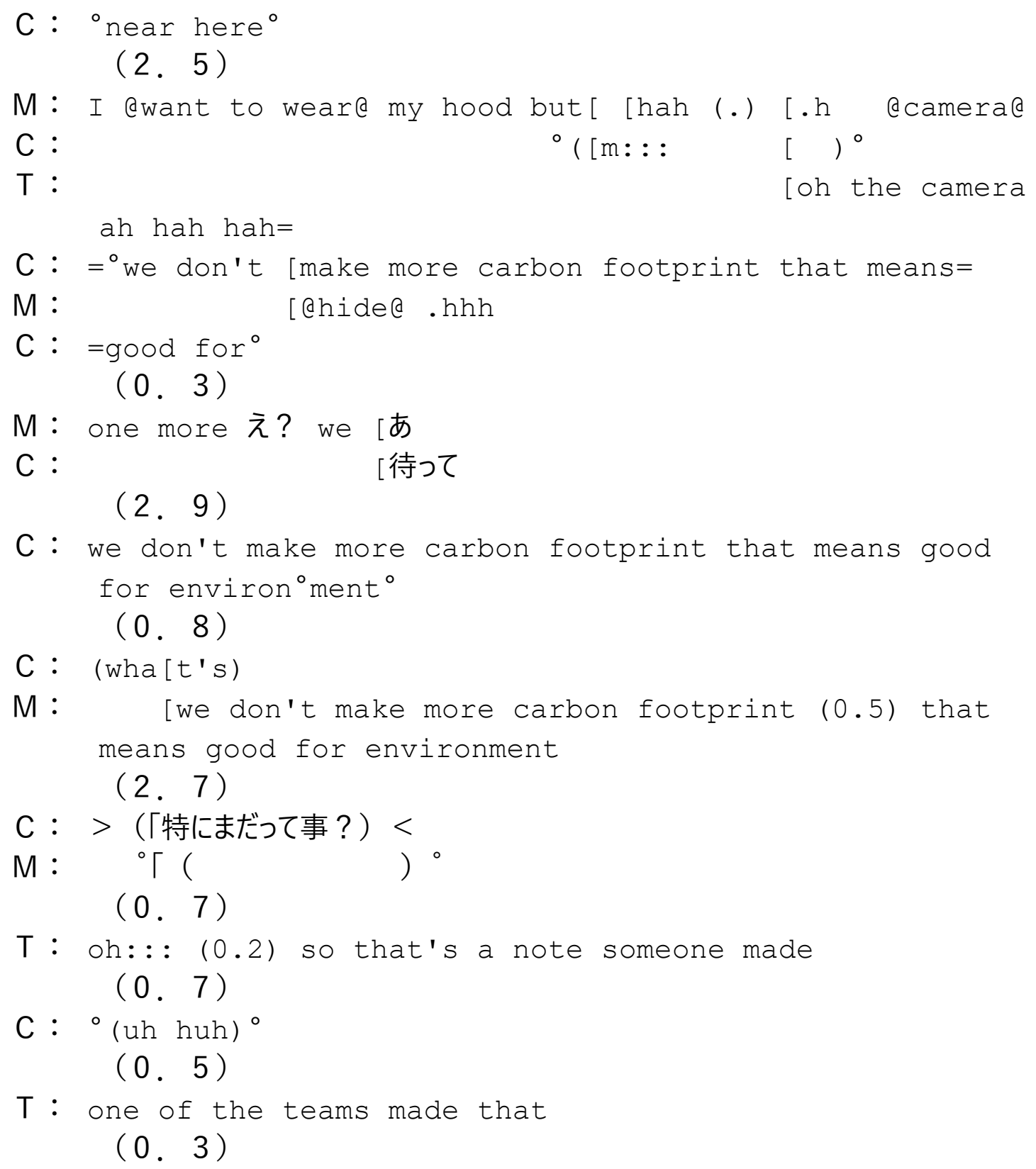

M : here?

(4.9)

M: huh @many $(0.4)>$ many Japanese people< ${ }^{\circ}$ to ${ }^{\circ}$ gethere C : ([hah hah) \$many people\$ $(0.4)$

T 2 : yeah

(2. 7) 


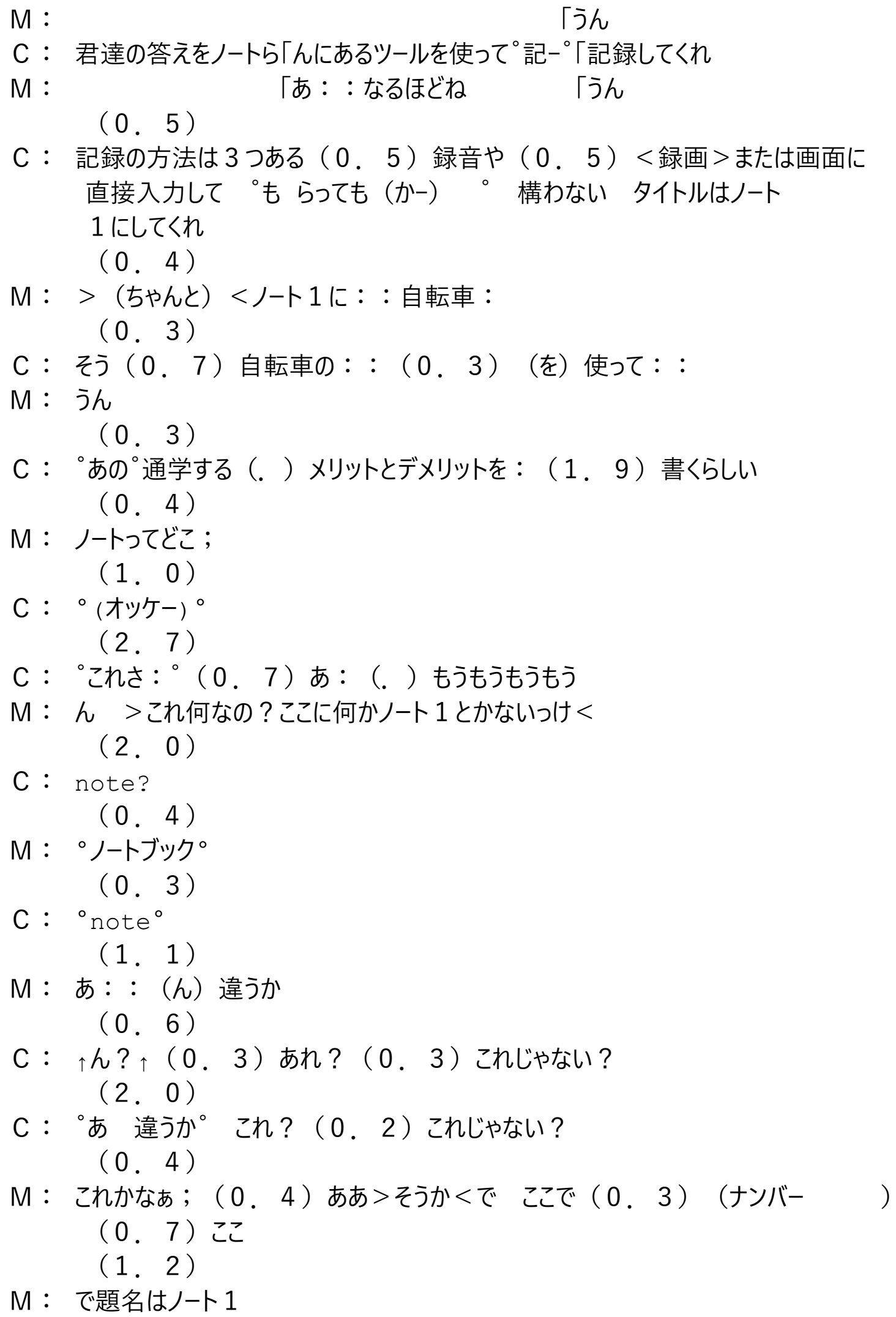


(2. 7 )

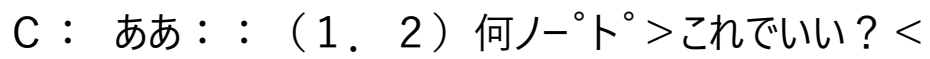

(2. 0$)$

$M$ : note one

( 0.7 )

$\mathrm{C}:{ }^{\circ} \mathrm{no}\left[\mathrm{te}^{\circ}\right.$

M : [本当これでいいのかな $(0.4)$ is it re- really? uh huh (4.5)

C : uh huh

( 0.7 )

M : nobody help us huh hah hah [hah hah .hh

C :

[yeah yeah yeah

(0.9)

C : ${ }^{\circ}$ self care? 自分で॰ (1.4) どうやって改行すんの 改行もしな い? ${ }^{\circ}($ どうすん の)

(1. 2)

$M ：$ リターン あ できないか（０４４）。リターン（じゃねえ）。

(2. 1 )

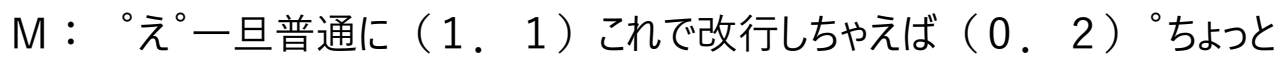
待って ${ }^{\circ}$

(1.8)

M：あれ？（0，2）え（. ）いない;

(1.7)

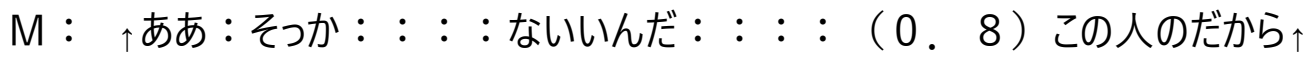

(0.2)

C ? ${ }^{\circ}\left(\right.$ (うそ) ${ }^{\circ}$

(1.2)

M：じやあ>駄目だ 「改行はできないく

C : $\quad$ 「改行できない゚

( 0.6$)$

C : ○じゃあ何にする?

(2.3)

C: we ca: :::::::n

(0.8)

M: we don't (0.8) ah:: : : : :

(1. 7 )

M：何て言うんだろう（0，2） はい（0．5）Ｃ０２（0.7）何だろう (1.3) 
C：削「減?

$\mathrm{M}:{ }^{\circ}\lceil$ はい

(0.4)

M：はい- 削減 排出しないとか（（「はい-」は排出の排と言おうとしている））

(2. 8)

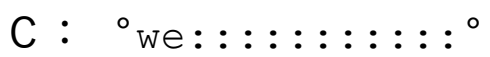

$(0.5)$

$M: \quad(\ulcorner\quad ;)$

C : $\quad{ }^{\circ} \Gamma()^{\circ}$

$(0.3)$

C: we: ::::::: don't (.) いや $(0.4)$ we: : : :

(1.3)

$\mathrm{M}$ : 排出

(2. 1)

M: discharge we don't dischar:: :ge (0.3) a lot of $\mathrm{CO} 2$

(2. 2)

C: ${ }^{\circ}$ don' ${ }^{\circ}$ t $(0.8)$ discharge?

( 0.3 )

M : discharge

(0.7)

[JAPESLSep072016HC4,6]

Group 1 continues to work on the location 1 prompt.

$(0.5)$

$C:{ }^{\circ}($ そうなの $) ?^{\circ}$

(2. 4$)$

C: dis:::: (1.4) char::::::: (0.2) ge?

(2. 6)

C : ${ }^{\circ}$ dis ${ }^{\circ}$ char: : : :ge;

(4.3)

$\mathrm{C}: \mathrm{CO} 2 ?$

(2. 2)

$\mathrm{C}:{ }^{\circ}<\mathrm{CO} 2>^{\circ}$

(3. 0 )

$C:{ }^{\circ} a:::: n^{\circ} d-$

M : - (and a/I) (0.3) emit carbon dioxideの方が>良かったか も< ( (excerpt 23)) 


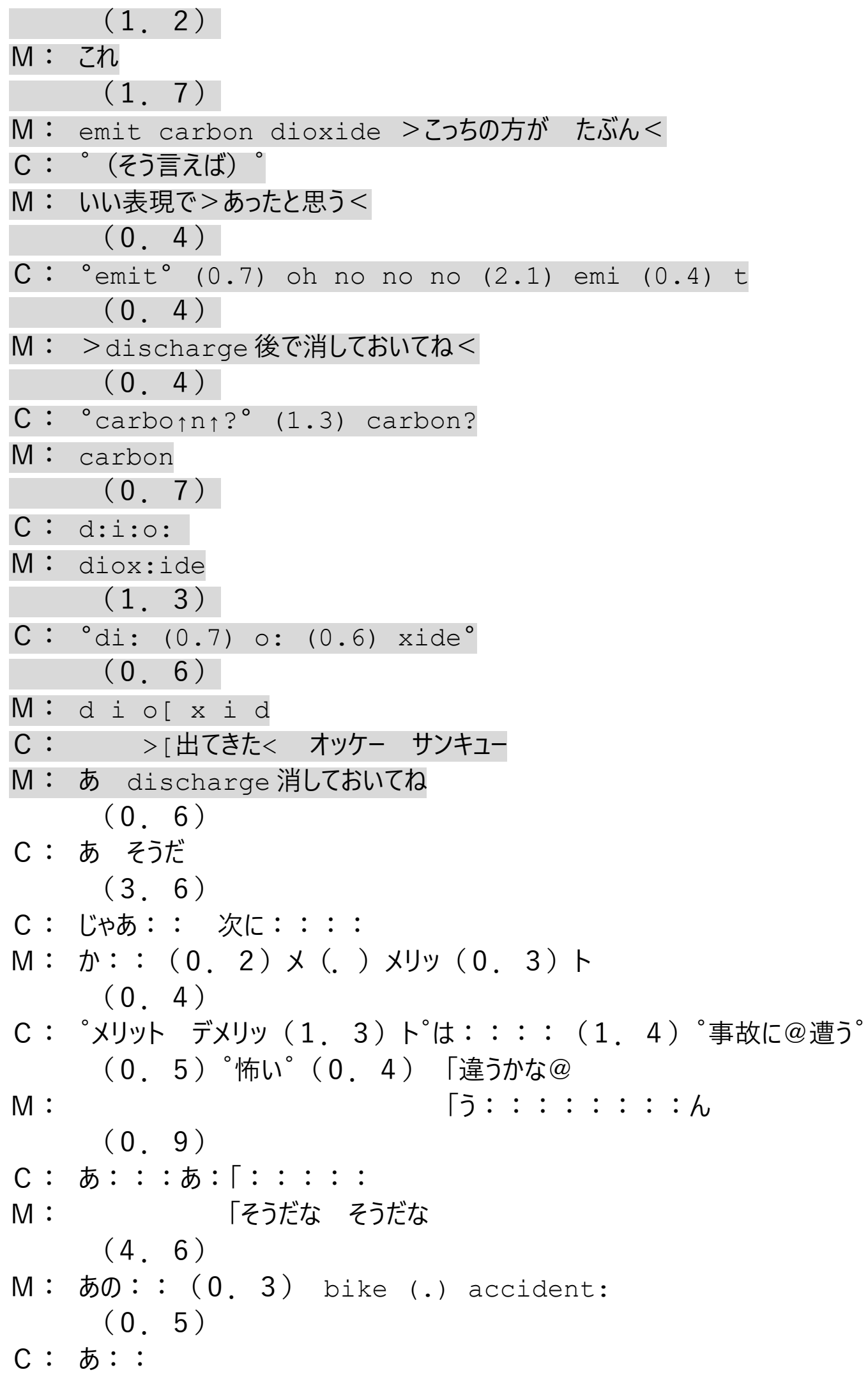




$$
\text { (0. 4) }
$$

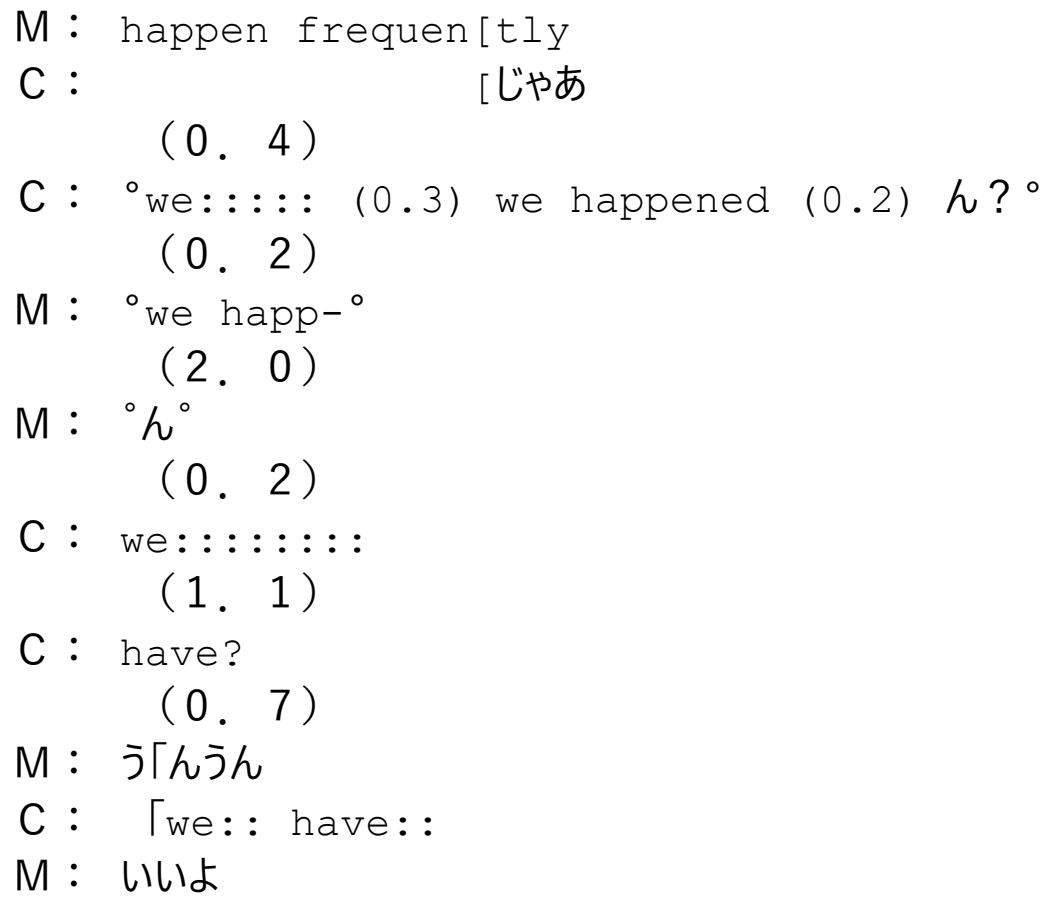

$\mathrm{M}$ :

$$
\text { (0. } 7 \text { ) }
$$

M: yeah we have bou- iPhone but (0.4) ${ }^{\circ}$ ah ${ }^{\circ}(0.2)$ my iphone can't use this a- (0.4) application

Z : okay

M: yeah (0.4) so I borrow (0.4) from my (.) ${ }^{\circ}$ teacher ${ }^{\circ}$

C : (0.6) teacher [なの

$$
\text { (0. } 4 \text { ) }
$$

$\mathrm{M}:$ オッケー?

(0.2)

C : save

(0.7)

$\mathrm{M}$ : maybe

(0.7)

C: let's go

Z: so when when you saw the instructions; 
M : uhuh

Z : was it in Japanese or was it in English.

M : Japanese;

(0. 6)

Z : okay

(3. 3)

Z : so everything's in Japanese

( 0.4 )

M: ah::::: no:: some (0.3) well there are (0.8) English

Z : okay

$(0.3)$

C : ${ }^{\circ}$ yeah $^{\circ}$

( 0.2 )

$Z$ : on the map is English=

(0.2)

$\mathrm{M}:$ =yeah yeah

( 0.7 )

C: two (0.4) Lincoln Hall $(0.8)^{\circ}$ we can $90^{\circ}$

$\mathrm{M}:$ Linco:r Ha: :ll

(0.4)

C: yeah $(0.2)^{\circ}$ (yeah yeah $)^{\circ}$

$\mathrm{M}$ : maybe

$(0.4)$

$\mathrm{T}:{ }^{\circ}\left(\mathrm{okay}\right.$ ) ${ }^{\circ}$

( 0.5 )

C : ○オッケー: ${ }^{\circ}$

$M$ : sorry (0.6) very $(0.6)$ wait wait

( 1.3 )

C: ${ }^{\circ}$ ah $(0.3)$ yeah yeah ${ }^{\circ}$

(1.8)

M： え ノート>できてるか＼cjkstart確認しといて ( (excerpt 24))

$(0.3)$

C : ${ }^{\circ}$ オ [ツケー: ${ }^{\circ}$

$\mathrm{M}: \quad[$ check

$(0.8)$

$\mathrm{M}$ : you can (0.2) make a note

( 1.0$)$

Z: can I- can I follow (.) [you guys playing the game? 


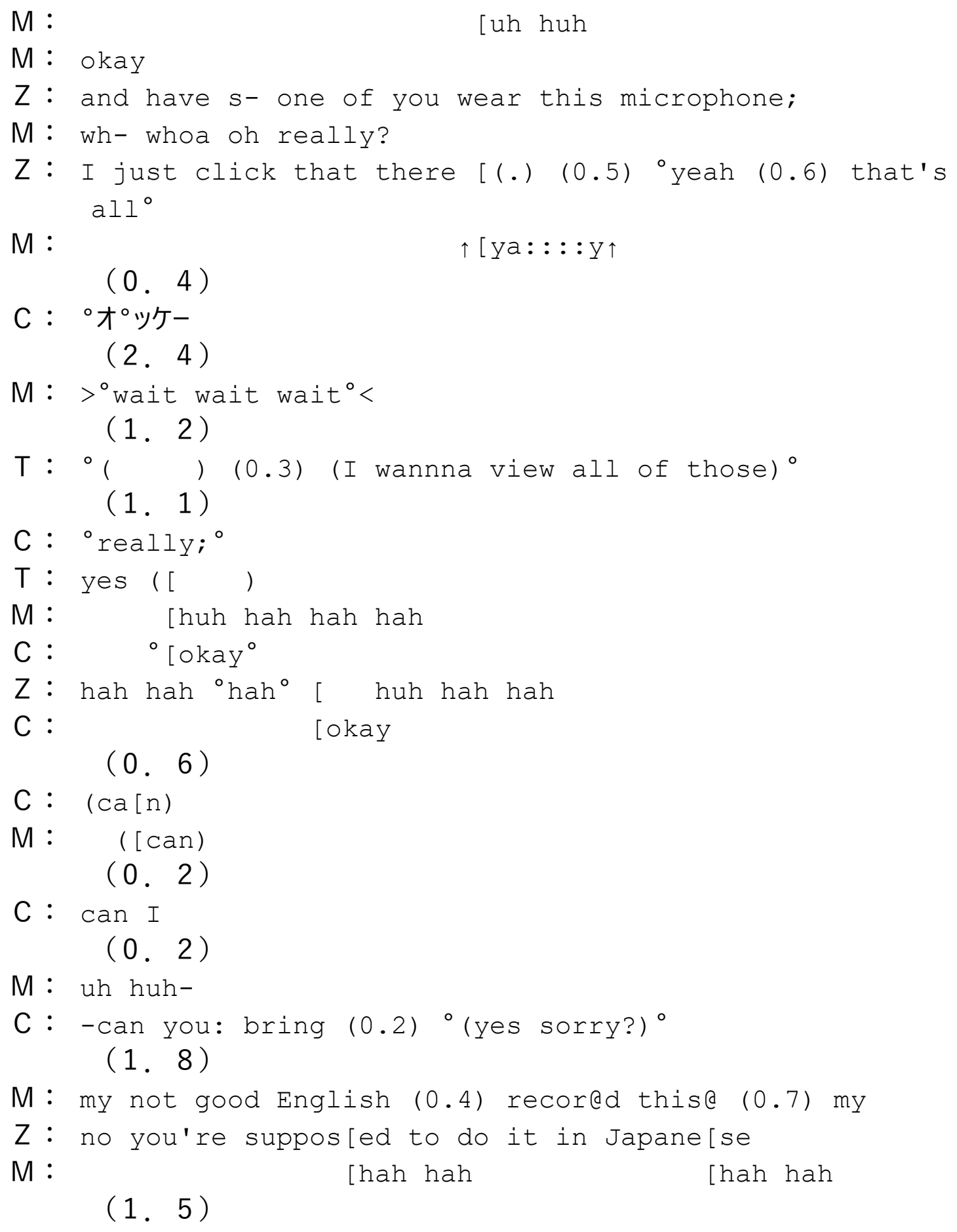


C: oh: ::: ${ }^{\circ}$ no: : : : ${ }^{\circ}$

(6.3)

$M:$ ऊ: : : h。

(5. 7 )

M：あ（．）あ（．）あ（０．２）>やばいやばい（０．３）やばいやばい<

((talking about the phone getting wet))

(5. 7)

M : <Lincoln Hall>

(2. 7 )

M: maybe two groups (0.2) already (0.7) come Lincoln Hall

C ? : ${ }^{\circ}$ オッケー ${ }^{\circ}$

(6.3)

M: and maybe next:: (0.8) ah: : : : $(0.2)$ [title (0.2) next: :

C ? :

(1. 0$)$

${ }^{\circ}\left([+)^{\circ}\right.$

M: ah assumption (0.6) is (0.5) like a solar (0.3) solar energy;

(2. 7 )

M : good point is can serve energy (0.6) あ 何か エナジーに 関すること related energy

( 0.7 )

C : ${ }^{\circ}$ related energy? ${ }^{\circ}$

M : (anyway) (0.2) [that (1.0) that people

C : $\circ[$ オッケー。

(1. 5 )

$\mathrm{M}$ : ああ

(3.9)

$M$ : 人の携帯なのに

( 0.3 )

C : ${ }^{\circ}::$ : ${ }^{\circ}$

(0.5)

$M:$ 濡れちゃう

(2. 6)

M : （タップ）え； 何付けて（る）（1０） ' hah hah hah hah.。 (3. 8)

M: ah hah (0.8) オッケー [ (0.5) オッケー

C ? :

[オッケー? ${ }^{\circ}$ 
(4. 8)

$\mathrm{M}$ ： え これ自分の声が録音されていると思うと（0７）恥ずかいい

(1.2)

C: ${ }^{\circ}$ yeah yeah yeah ${ }^{\circ}$

$\mathrm{M}:$ yeah

(2. 4 )

C : can I

( 0.4 )

$\mathrm{M}$ : uh huh;

(0.8)

C: ${ }^{\circ}$ have this ${ }^{\circ}$

$\mathrm{M}:$ yeah

(3. 4)

$\mathrm{M}$ : maybe that groups

(0.5)

C: yeah yeah

(0.9)

$\mathrm{M}:$ Lincoln Ha: :11

(2. 5 )

M: maybe Lincoln is (0.2) president (0.2) of Ame[rica

C :

ㄷ uh huh ${ }^{\circ}$

$$
\text { (0.9) }
$$

$\mathrm{M}$ ： え 知ってるよね；

C : ${ }^{\circ}$ jh

$M:{ }^{\circ} j h^{\circ}$

$(0.7)$

C?: ${ }^{\circ}$ (of course) ${ }^{\circ}$

(6. 9)

$M:$ can I get $(0.3)$ ge-

( 0.6$)$

$M:-t$ to: : (0.3) get

(7. 9)

C: I can't (0.5) (how is this)

(3. 2 )

C: (one/why)

(3. 3)

C: ${ }^{\circ}$ (one) ${ }^{\circ}(0.6)$ jh?

(0.3) 


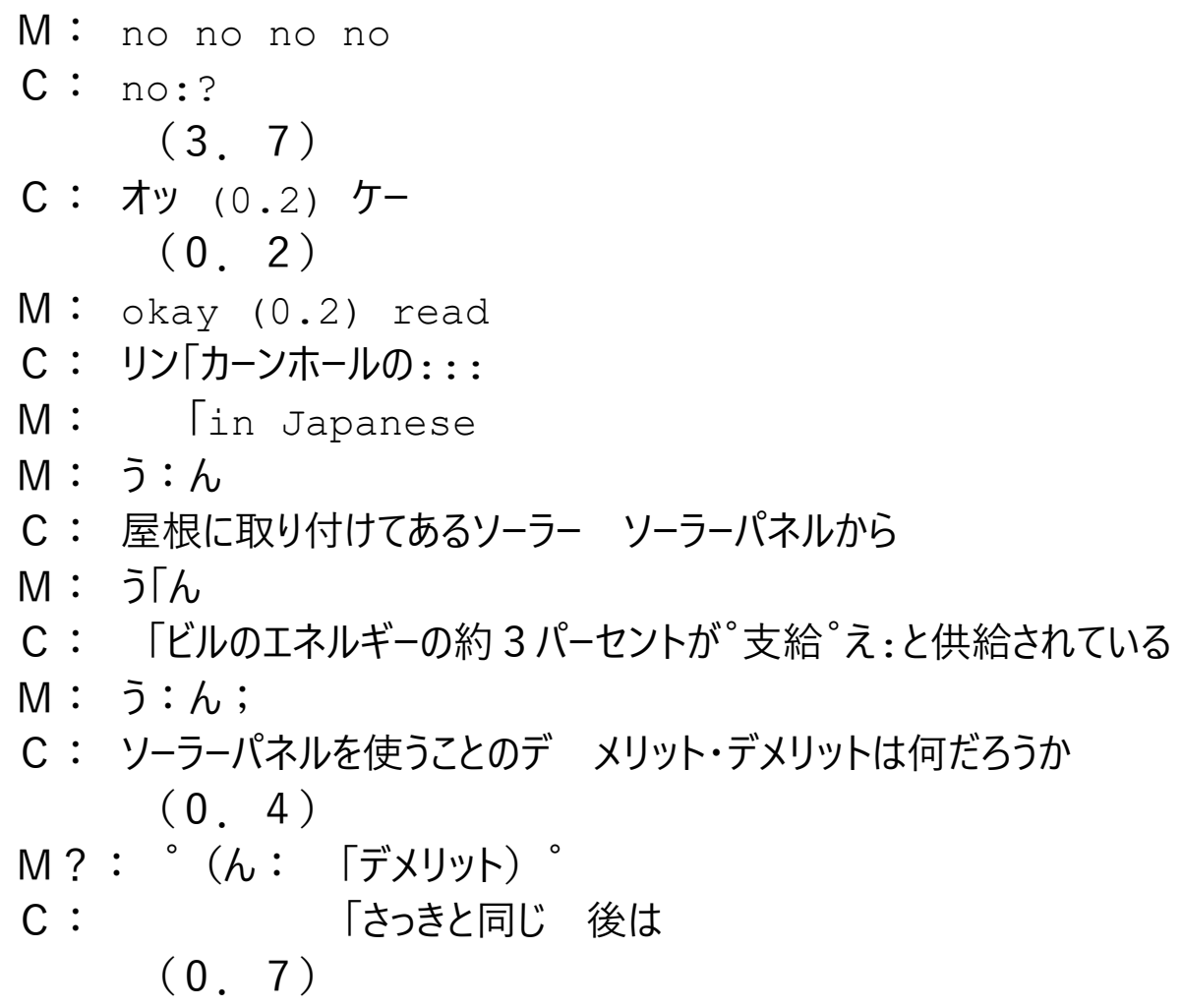


C:（いや）（. ） ah:::: solar panel::::: :

$\mathrm{M}$ : solar panel's

(0. 4)

\section{[JAPESLSep072016HC4,8]}

Group 1 continues working on the location 2 prompt.

C ? : え : :「: ${ }^{\circ}($ メリット ; )

$M: \quad \quad$ merit

( 0.5 )

$\mathrm{M}:$ j: : : : ん

(1. 2)

$C:$ kind for: $:[:::$ :

$M: \quad[$ don't use

(0.5)

Z: You have new group members [(.)

$C: \uparrow^{\circ} え::\left\lceil:{ }^{\circ} \uparrow\right.$

Z : $\quad$ They're gonna join you 'cause their iPad is not working

M : ah:; okay.

(1. 3 )

?: hello

(1. 9)

C ： えっと：：：（０．5）ソーラーパネルを：使うことによって：：：

（0８）メリットとデメリットを：：（0，6）このノートで書く

(1. 2)

C : ${ }^{\circ}$ So: : : : ::: ${ }^{\circ}(0.6)$

$\mathrm{E} ：{ }^{\circ}$ ソーラーパネルで

(0.6)

C : yeah

M： まあelectricityを使わない>ところくじやない；

(0.2)

C： ‘あ：： : また゚

(0.9)

$\mathrm{E} ：$ 自然（．）ナチュラル：：エネルギー

$\mathrm{M}$ ：ナチュナルパワー的な=

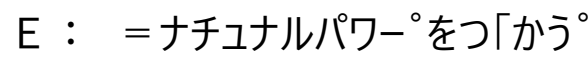

$M ： \quad$ 「ナュラル（） 自然の 


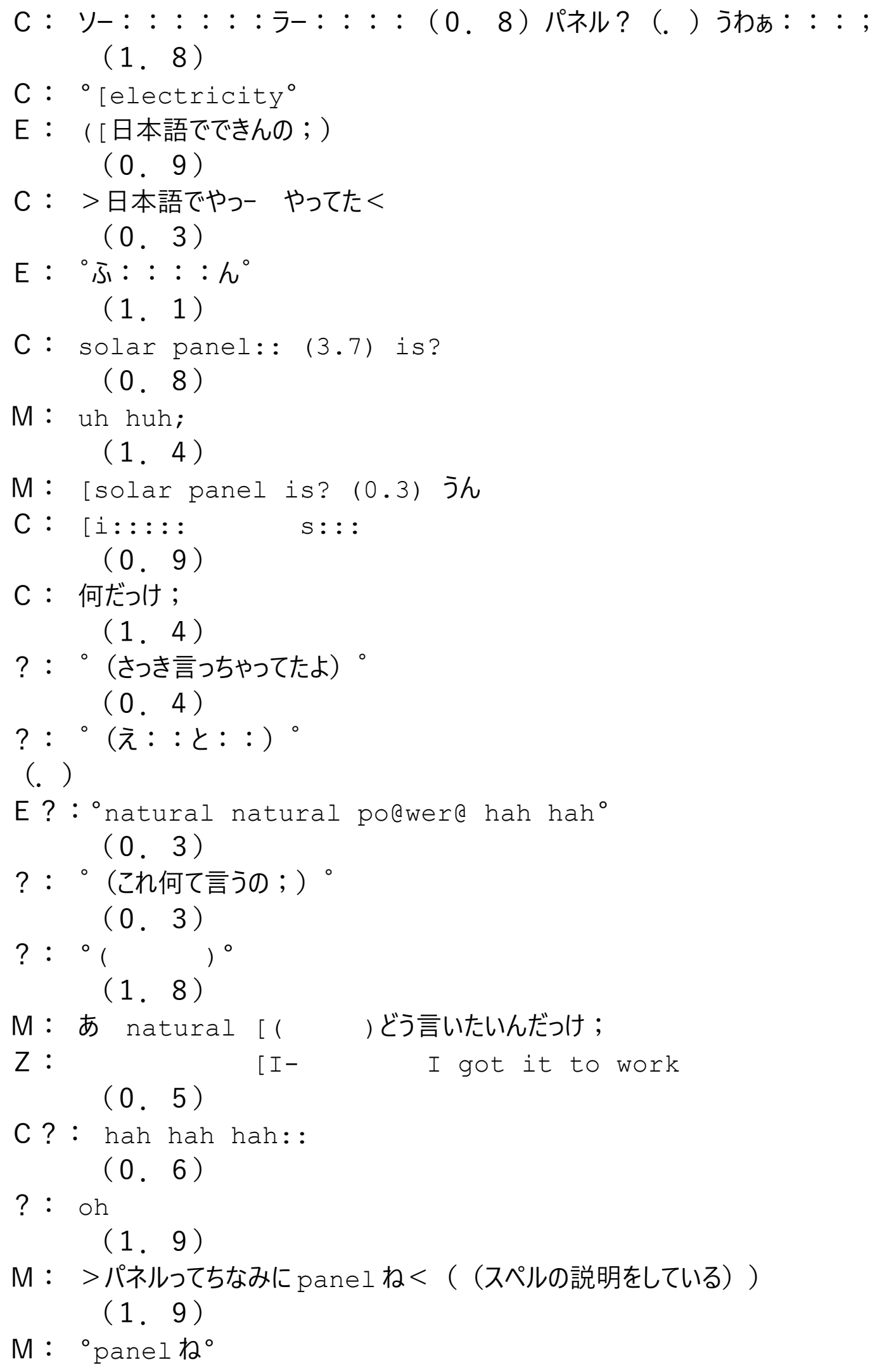


C：何か：（0.3）変換で出てきた

(1.4)

$\mathrm{M}$ : solar panel is

(1.4)

C：何 何 何

M： isって言うか まあ $(0.2)$ don't use [electricityでしょう やっぱ

C :

$$
\text { (0.7) }
$$

[あ：オッケー；

M：電気使わないことがでかいでしょ；

$C:{ }^{\circ}(\text { don't })^{\circ}(0.4)$ あ:もう

( 0.6$)$

$\mathrm{M} ：$ 勝手に 大文字になっちや「う

C :

「そう

(1. 0$)$

$\mathrm{M}:$ don' [t

C: $\quad$ don't $u::::::$ se

$M$ : use (1.5) electrici[ty

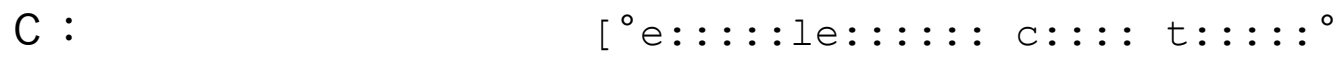

(0.4)

$M:>(\quad)$ だね; <

$(0.3)$

C: le? (0.6) ri? (0.3) r?

(1. 8)

M : electri-うん たぶんrかも

C：ri ci? [ ty $(0.4)$ 出ないね

$M ：$ [違うかな。

$M ：$ ○あ出ないね え ricityつて（s）かも

(0.6)

C : オッケー (0.9) city

( 0.3$)$

$\mathrm{M}$ ：あ 出ない (1.4) elec [t

C： [jん；（0，7）でもこっちじやないよね

(1. 4)

C : ricityでしょう

$\mathrm{M} ：$ う：何か：：変だよ゚ね。

(3.7)

C : electricだから::: (0. 2) ri::ci:::: :

(3. 9) 


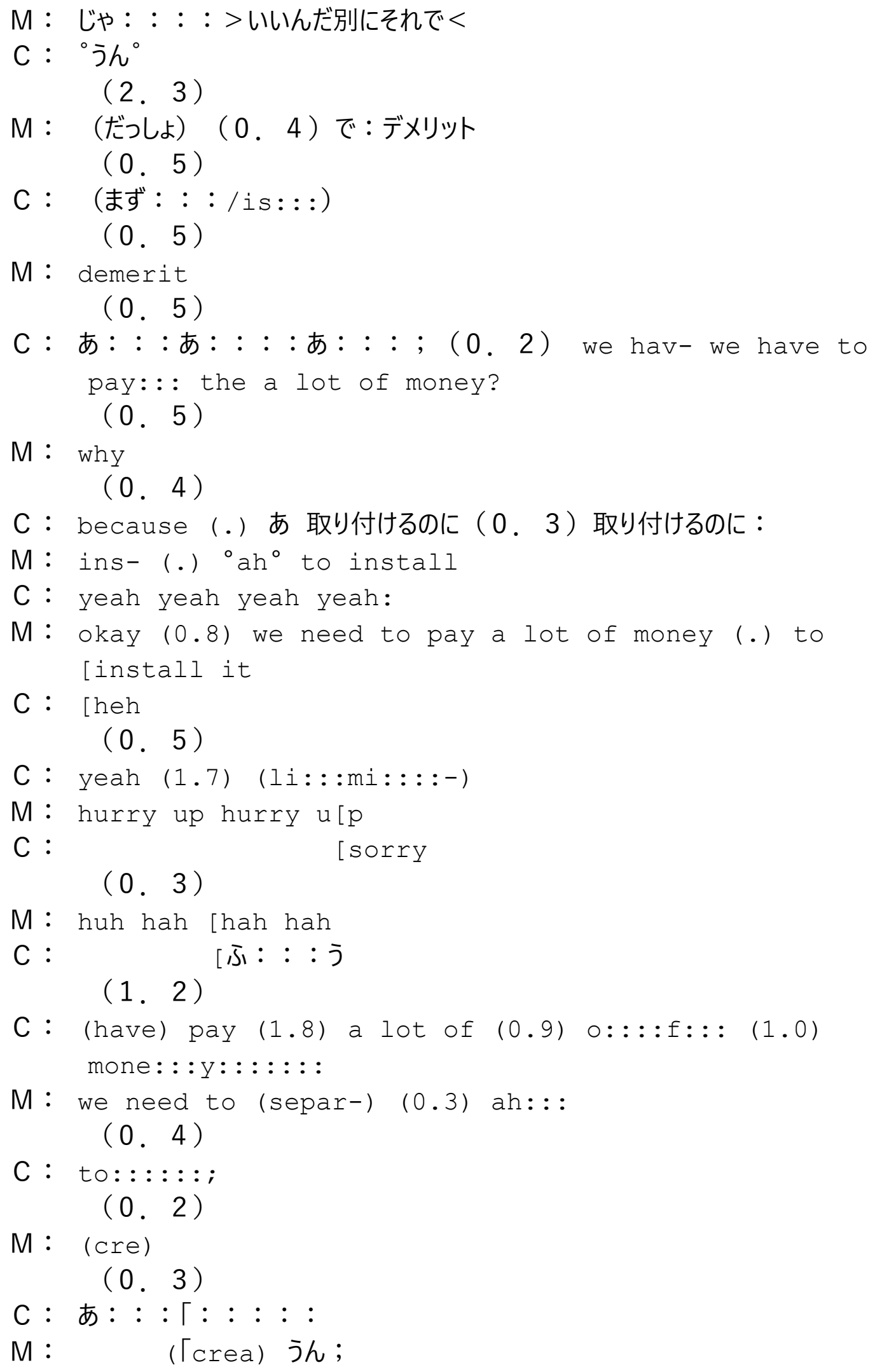




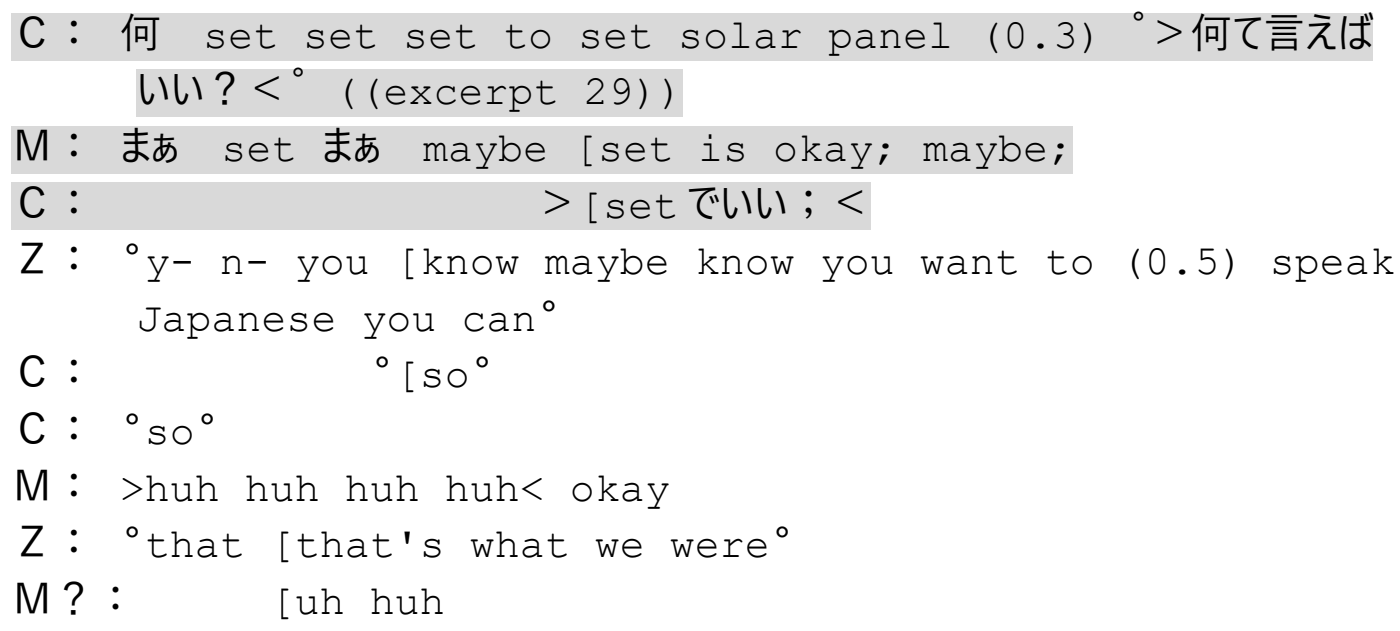

[JAPESLSep072016HC4,9]

Group 1 finishes inputting the location 2 response and heads toward location 3.

( 0.8$)$

C : ${ }^{\circ}>$ (何 ちよつと今) $<{ }^{\circ}$

Z : ${ }^{\circ}$ (you don't have to speak) ${ }^{\circ}$

M：日本語でも別にいいって

$$
\text { ( } 0 \text {. 7) }
$$

Z: ${ }^{\circ}$ ( language $)^{\circ}$

M : huh huh huh

$$
\text { (0. 8) }
$$

C: save

$$
\text { (1. 5) }
$$

M： save； (.) ああ。

(0. 2)

C : オ $[$ ッケー

$\mathrm{M}:{ }^{\circ}\left[\right.$ いい ${ }^{\circ}(0.6)$ オッケー?

(0.3)

C: yeah

$\mathrm{M}$ : really? 本 $\uparrow$ 当 $\uparrow$

C： え >本当本当< さっきと同じやり方や

$\mathrm{M}:$ ほう ふ：：：：：ん

(0.3)

C : ほう ふ：：：：ん（（CはMの言い方を真似ている））

$$
(0.2)
$$

$\mathrm{M}:$ ふ: : : h $(0.9)$ next is 
(0.3)

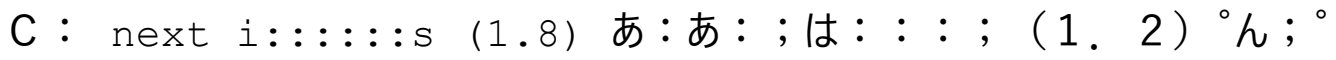
こつから来たつけ： ;

(0.5)

$M ：{ }^{\circ}$ い゚やこっちからこう来た（）

(2.6)

$\mathrm{M}:$ オッケー;

(1.1)

C： カ゚歩いてみ「ないと（あ： :るこう）。

$\mathrm{M}$ ：「うん $(0.3)$ ネクスト

(4.2)

$\mathrm{M}$ ：あ メッリト•デメリット書く (際) さ：：：（0３）メリット い-

C : ○あれこ「れ゚

M： 「>デメリットってちやんと分けてやった方がく

(0.3)

C: ${ }^{\circ} j h^{\circ}$

(0.8)

$M ：{ }^{\circ}$ 分かりやすいと思う゚

C: $\begin{gathered}(0.5) \\ \text { 。こかな } \\ (10.6)\end{gathered}$

$M ：$ 本当に動いてないね（1，2）いや微妙に動いてる

(0.5)

C : 合ってる

$(0.4)$

M：うん 進んでる向こうに（0．8）あ>向こう†進んでいいの何もない もしかしてく

(0.3)

C : え?

(1. 0$)$

$\mathrm{M}$ ：あこれ：？（0．2）これ；これ；これ；（1，5）これ；これ；

(2.1)

C：逆や：：

$(0.4)$

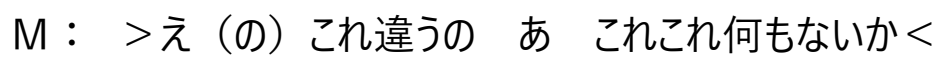

(0.9)

C：逆だ ごめん

(0.2) 


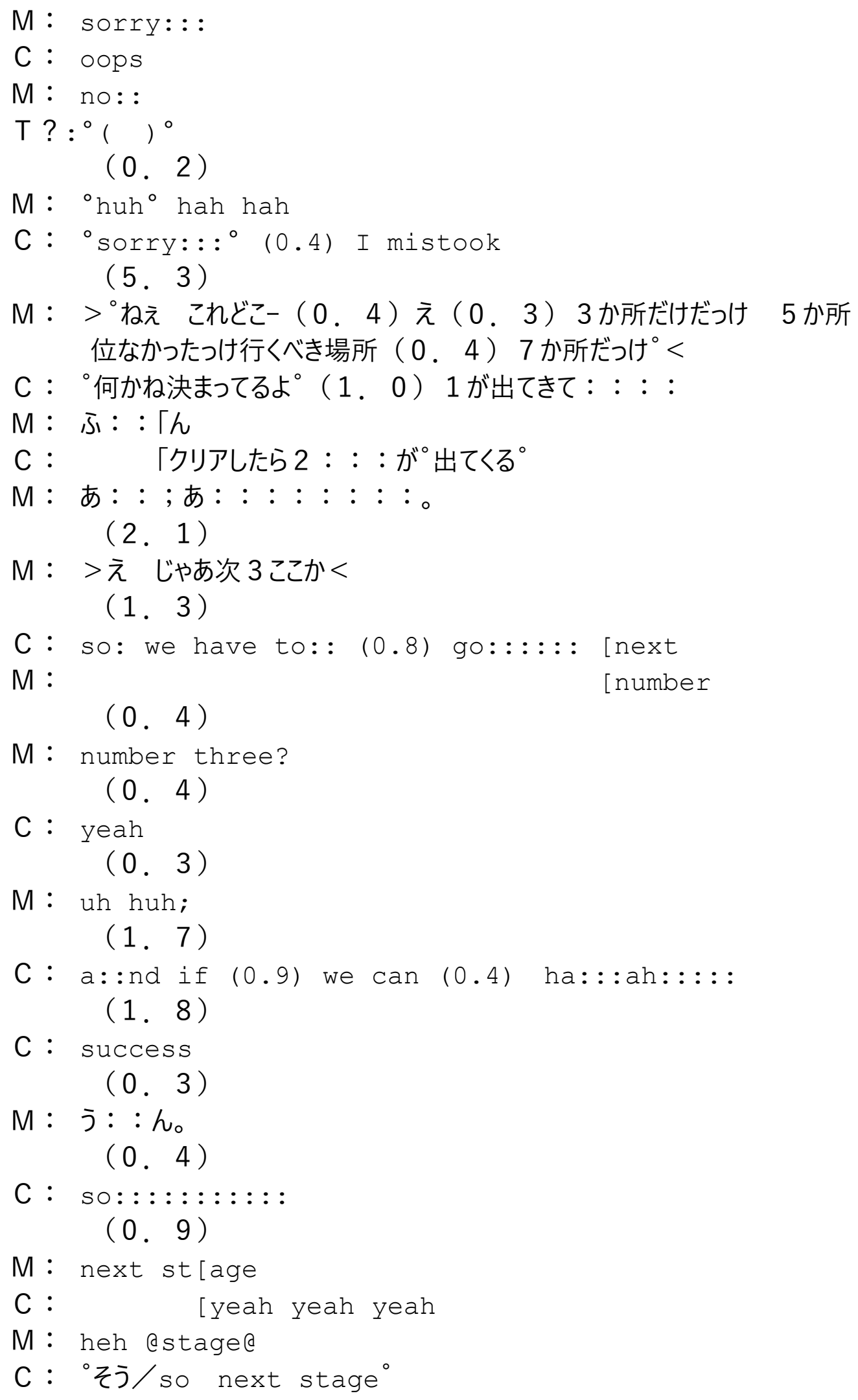


(1.8)

$\mathrm{M}$ ：>ねえ これどこまで これ（ボー）< あれ：：録画され（ど）いつ まで：：（0．6）あれ：：（0．9）カメラに収められちゃうの俺ら (0.5)

C : aI don't knowe

( 0.7 )

M： scaryなんだけど：若干（0５） a little bit scary (5.1)

$\mathrm{M}$ : い（さ）この この距離だよ このマイク

(0.9)

C : ${ }^{\circ}$ 確かに

( 1.0$)$

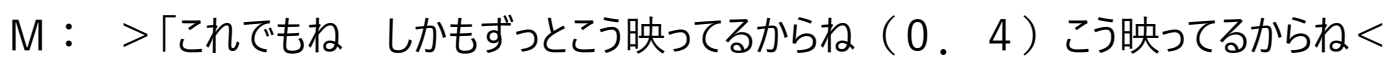

C : (「ここの声も)

C : ${ }^{\circ}($ ね $)$

(1. 1)

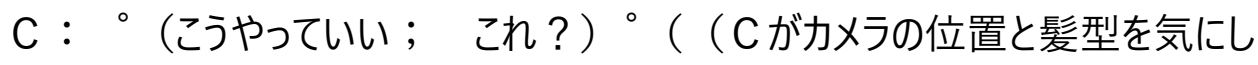
ている) )

(0.3)

M : そう それがいい (0.3) good (.) good: : (0.4) huh (2.4)

C : ‘あ（何もない；）。

( 0.7$)$

M：＞髪とか気にしてる場合じゃね もう変わんねえよ もうく（0，8） huh

(5.3)

M： あ もうそこなんだけど（1，2）場所としては

(2. 0$)$

C : oh: : : : : :

(0.9)

M : (that building) ((excerpt 25))

( 11 1.9)

$\mathrm{M}:$ オッケー： .

$(3.7)$

$\mathrm{M}$ ：あ：：（．）人通るからこの辺に

[JAPESLSep072016HC4,10] 
Group 1 works on the location 3 prompt.

(2. 8)

$\mathrm{M}:{ }^{\circ}(\text { the })^{\circ}(1.3)$ これ
$\quad(0.4)$
$\mathrm{C}: \quad$ (yeah yeah)
$\quad(4.9)$
$\mathrm{M}: \quad$ > 何てこot : : $\quad(0$

M： ®>何てこった：：<（0４4）エレク-（0，2）エレクトリック

（０８）アベニューは＞一体どうなったんだ：：<（０．2）

ここは：（．）電気自動車を無料で充電できる場所 >なのに<（０．2）

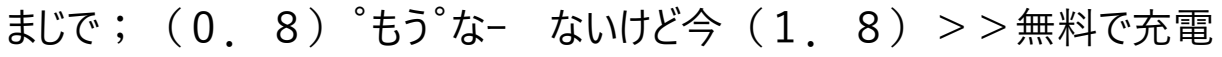

でき んだってく<（1．0）もしかしてこれは：：グリーンテクノロ

ジーの終わりを告げー（0．5） るのだろうか（0．5）君達の答@えを

ノートに@® 何

(0.2)

C : @(ち：：がえど：：)@

(0.9)

$M ：$ 電気自動車を無料で充電できる場所だった

(3.4)

$M ：$ あ：>どうなったんだって あ：だからこれを見てどうなったん「だっ

つてんだねく

C :

$(3.0)$

C ? : (

M：>（果たして）これはグリーンテクノ「ロジーの終わりを告げるの

だろうかく

C : $\quad \Gamma^{\circ}{\text { (what })^{\circ}}^{\circ}$

(0.6)

M : > @君達の答えを@<い- 意味が分からない

C : uh hah hah hah

$(0,2)$

$M:$ え: : : : : ;

(3.5)

C : 新しいものを作っている

(6. 0 )

$M ：$ 全部ノート1でいいのかな：題「名

C : ${ }^{\circ} \Gamma j j h^{\circ}() .3(0.2)$ 多分

$\mathrm{M} ：$ ○あ そうかノート3か：。

「あ：：：あ：：：：。

(3. 5) 


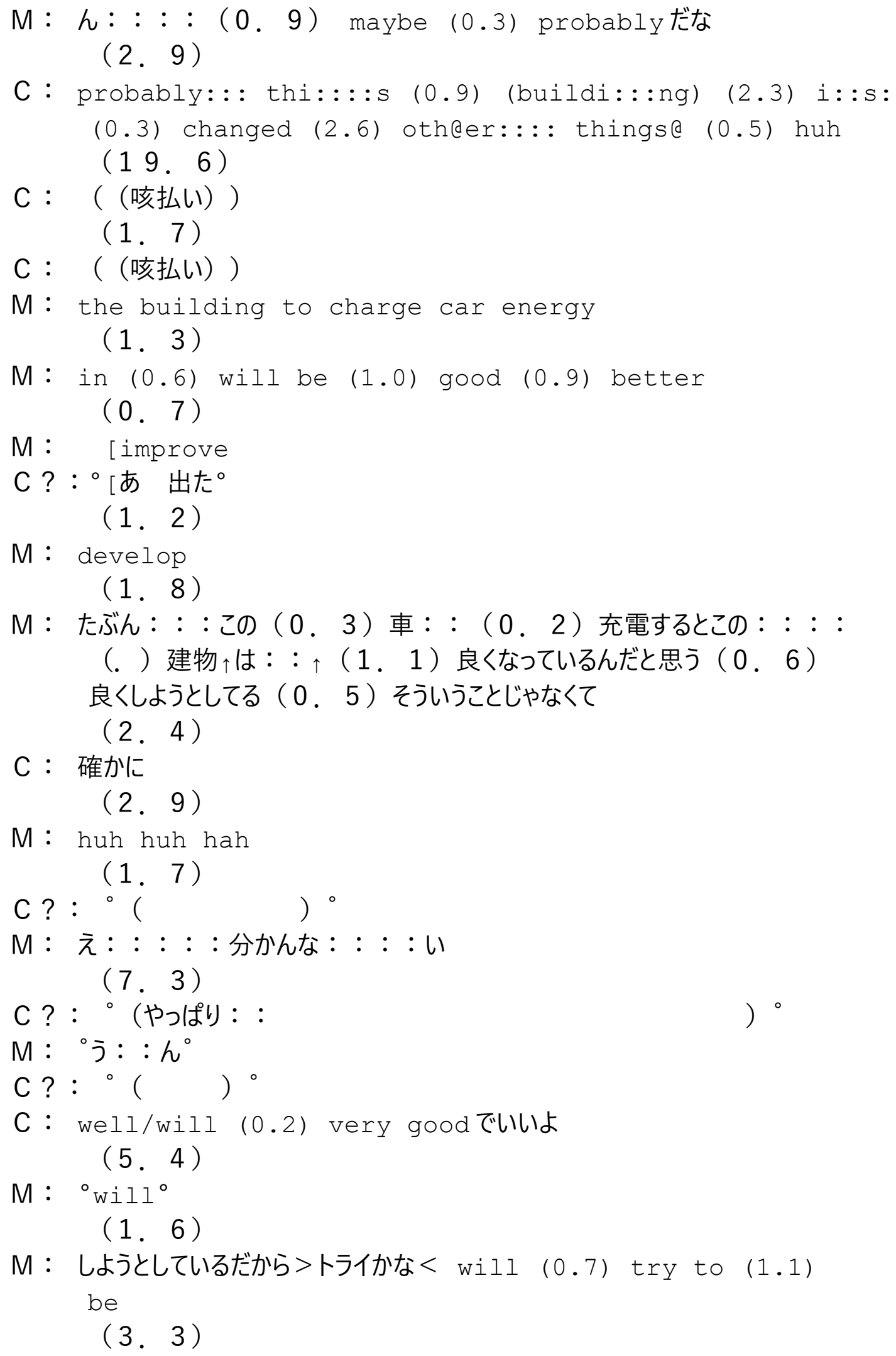


M : better

C?: ${ }^{\circ}(5)$ 事 $)^{\circ}$

$\mathrm{M}$ : better one

(1. 6)

M : probably: : the building; to charge a car energy (0.6) will try to $(1.5)$ be (1.9) try to be. (0.4) better one

\section{[JAPESLSep072016HC4,11]}

Group 1 finishes the location 3 prompt and then heads toward location 4.

(1.9)

M: yeah save

$(0.6)$

C: ${ }^{\circ}$ a: : : : nd $(0.5)$ yeah $^{\circ} \operatorname{maps}(0.2){ }^{\circ} \circ \mathrm{kay}^{\circ}$

(1. 1 )

M : four (1.3) あった four

(3. 9)

C : $9 \circ:$

$\mathrm{M}:>$ や

(4. 2 )

M: oh: (0.5) huh

(2. 8)

M : maybe: : : : : : : : : :

(1. 4 )

C: here?

(1. 0 )

M: that way

$\left.\mathrm{D}:{ }^{\circ}(1,7)\right)^{\circ}$

M : はあ (0. 2) Rachel (0.6) Rachel ( (calling to T))

$\mathrm{T}:$ yes

$M:$ finish nex $[t$

$\mathrm{T}: \quad$ [finished $(\quad)$

$\mathrm{M}:$ yeah=

$\mathrm{T}:=\mathrm{okay}$.

(4. 6)

C: ${ }^{\circ}\left(\right.$ Rachel) ${ }^{\circ}$ 
(0.3)

M：>あ どこ大通り これ大通りだよね あ やばい 人来るく

$T$ : finished or not yet

$M:$ not yet

C : ${ }^{\circ}$ not yet $^{\circ}$

$M:$ [next is number fou $[r$

T: [oh [oh okay

(0.6)

M: ah sorry maybe no $(0.6)$ huh $(0.5)$ which is this $(0.3)$ this $(0.3)$ big way

$(0.3)$

$\mathrm{T}:{ }^{\circ}$ uh huh $\left[:^{\circ}\right.$

M : [big: : street is this;

(1. 1)

$\mathrm{M}: \quad[$ so: : : : :

T : [Broadway

?: ${ }^{\circ}$ huh huh huh ${ }^{\circ}$

$\mathrm{M}$ : and so:

( 0.7 )

T: ${ }^{\circ}$ umm; okay? ${ }^{\circ}$

( 0.3$)$

$\mathrm{M}$ ： ああ やっぱいい「のか

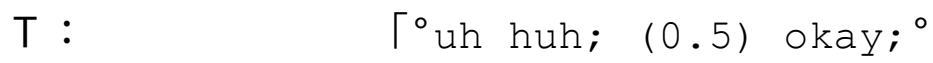

M : uh huh

(3.1)

$M$ ：自分の（）> >方向感覚に自信が持てません<

(0.9)

C : ${ }^{\circ}$ huh huh huh ${ }^{\circ}$

(0.7)

$\mathrm{M}$ ： 誰かいる?

(1. 6)

C ?: ${ }^{\circ}$ j:: : : : : : : : : : $: h^{\circ}$

$\mathrm{M}:>^{\circ}$ 他の連中 ${ }^{\circ}<$

T ? :

(0.2)

C ? : ${ }^{\circ}$ (hungry) ${ }^{\circ}$

T: I'm hungry already

$M$ : yeah: : [:::: . 


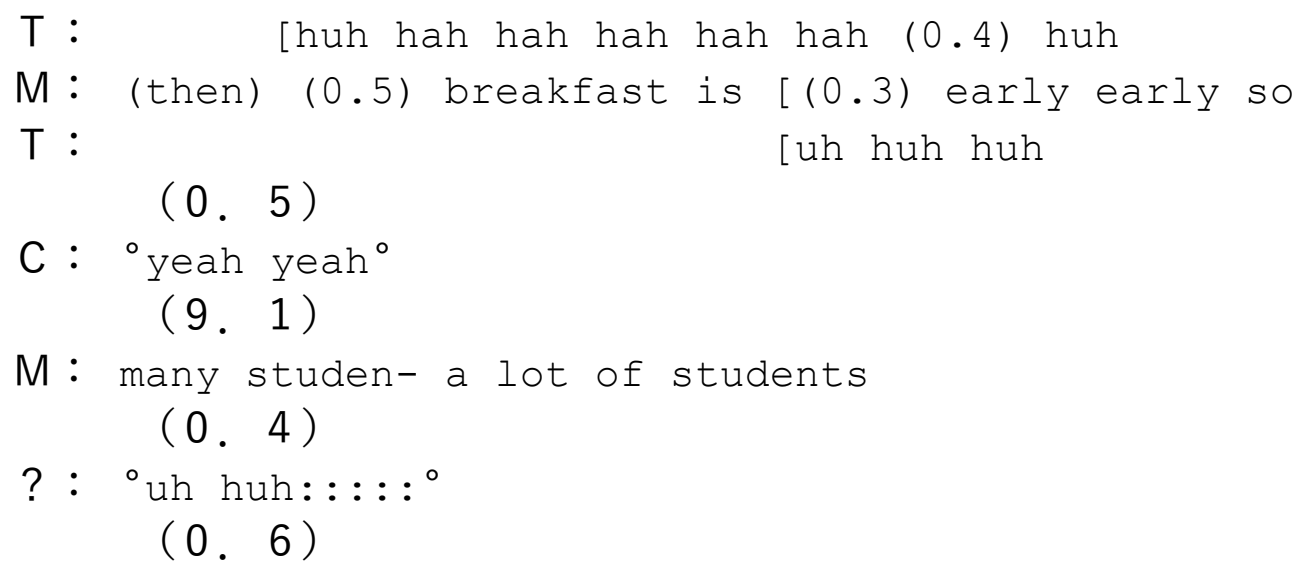

M : Academic and Student Recreation Center

(3. 1)

M ? : ○(いそ- 急がない) $。$

( 1. 1)

C ? : `ちと

(1.6)

$\mathrm{M}$ ：ねえこの この録音された声達と：：（０６６）録音された：： :

（０．２）つたない英語達は：（0．2）公開されるのどつかに（0．9）後で みんなで：：（1１）鑑賞会なの

(0.3)

C : ${ }^{\circ}(\text { そなりに考えてくれるよ })^{\circ}(0.8){ }^{\circ}{\text { (maybe })^{\circ}}^{\circ}$ 
(0. 2)

$\mathrm{M}$ : maybe

$(0.5)$

$C:{ }^{\circ}\left(\right.$ sorry $:[:)^{\circ}$

M : [sorry;

(2. 4$)$

M : あ：やっぱあれだ（1，0）あいつらの（０．4）あ>ごめんね< (0.4)

C : ${ }^{\circ}$ sorry; ${ }^{\circ}$

(1.1)

C ? : ( (小さな咳払い) $)$

(2.7)

M: so we: : (0.2) make a note here

(0.6)

C : オッケー

$M ：>$ 何か同じ場所でやんのが何かちょつとやだく (4.0)

M: え: : と:>Academic and Student Recreation Center カッコ A R C - （0.3）S Cの（．）トイレの水には ; < (0. 2)

[JAPESLSep072016HC4,12]

Group 1 works on the location 4 prompt.

( 0.4$)$

$\mathrm{M}$ ：屋根で：：：（０，3）集めた：：：（0，6）雨水が使われてるんだっ て（1，0）雨水の：：：他の 利用法はないだろうか

(3. 9)

M: another:: : (0.3) me- (1.5) ah: : : ::: $(0.6)$ use (0.5) how to use $(0.4)$ the $(0.5)$ rain $(0.6)$ water (.) rain water; ${ }^{\circ}$ 何 ${ }^{\circ}$

(2.8)

M: they have any (0.5) ((咳払い) ) (0.8) any: : :

(1. 2)

$M: i[$ dea?

$C:{ }^{\circ}\left[(\text { yeah an: }: d)^{\circ}\right.$

(2. 0$)$

C : うわあ $「:$ : : : ; 
M: $\quad$ 「note four: : :

(3. 4 )

$\mathrm{M}$ ：>そもそも雨水って英語で何て言うのか調べておこう（０．2）その@間 に考えといて@く

(7.5)

$\mathrm{M}:$ オッケー: ?

(3.4)

M：rain waterだった>まんまじやねえかく

C : えええ：：：：：：;

(4.4)

C：え何か：：：（）承とかにするって思ったけど別に水とかにしても今：

: : ; (0．５）その色々発達してるから : : : =

$\mathrm{M}:=j::: h$

(0.2)

C : ( ) とかで斉む「じやん

$M:$

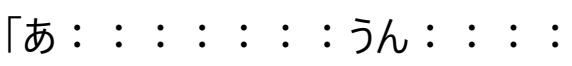

(1.3)

C ? : ${ }^{\circ}$ (プル) $^{\circ}$

$\mathrm{M}:$ j: : : : : : h

(0.9)

C : ${ }^{\circ}$ 雨水でしょ

(3.4)

$\mathrm{M}$ ：あ「ま水を

C : 「ドリンクは無理じやん

$\mathrm{M}:{ }^{\circ} \mathrm{h}^{\circ} \quad$ 净水する

( 0.4 )

$\mathrm{C}$ : ${ }^{\circ}$ あ 浄水しよ : $=$ 。

$\mathrm{M}$ ：=雨水 $(1.6)$ 浄水って>英語で何て言うんだろう rain water 分かった<

(2.2)

$M$ ：浄：（．）水（1，2）英：語（1，0）>>これ後これ録音された後で 公開だと：恥ずかいいん だけどく< (0.4)

C: ${ }^{\circ}$ hah hah [hah hah hah $\left[:^{\circ}\right.$

M : [huh [huh

(0.2)

$\mathrm{M}$ ：こいつ（）（＠雨水「浄水@調べてやがるってなる

C: $\quad{ }^{\circ} \Gamma$ huh hah hah ${ }^{\circ}$ 


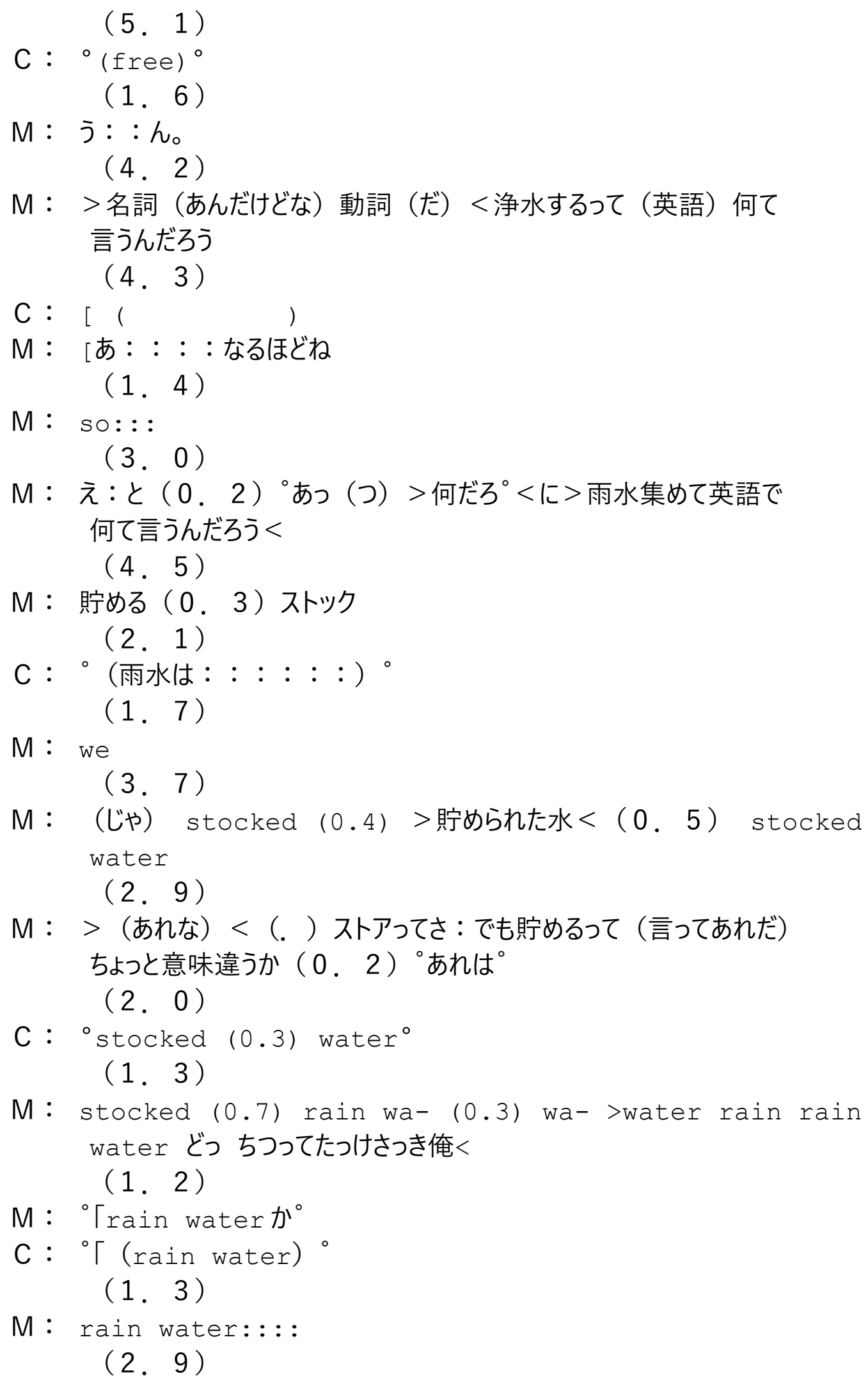




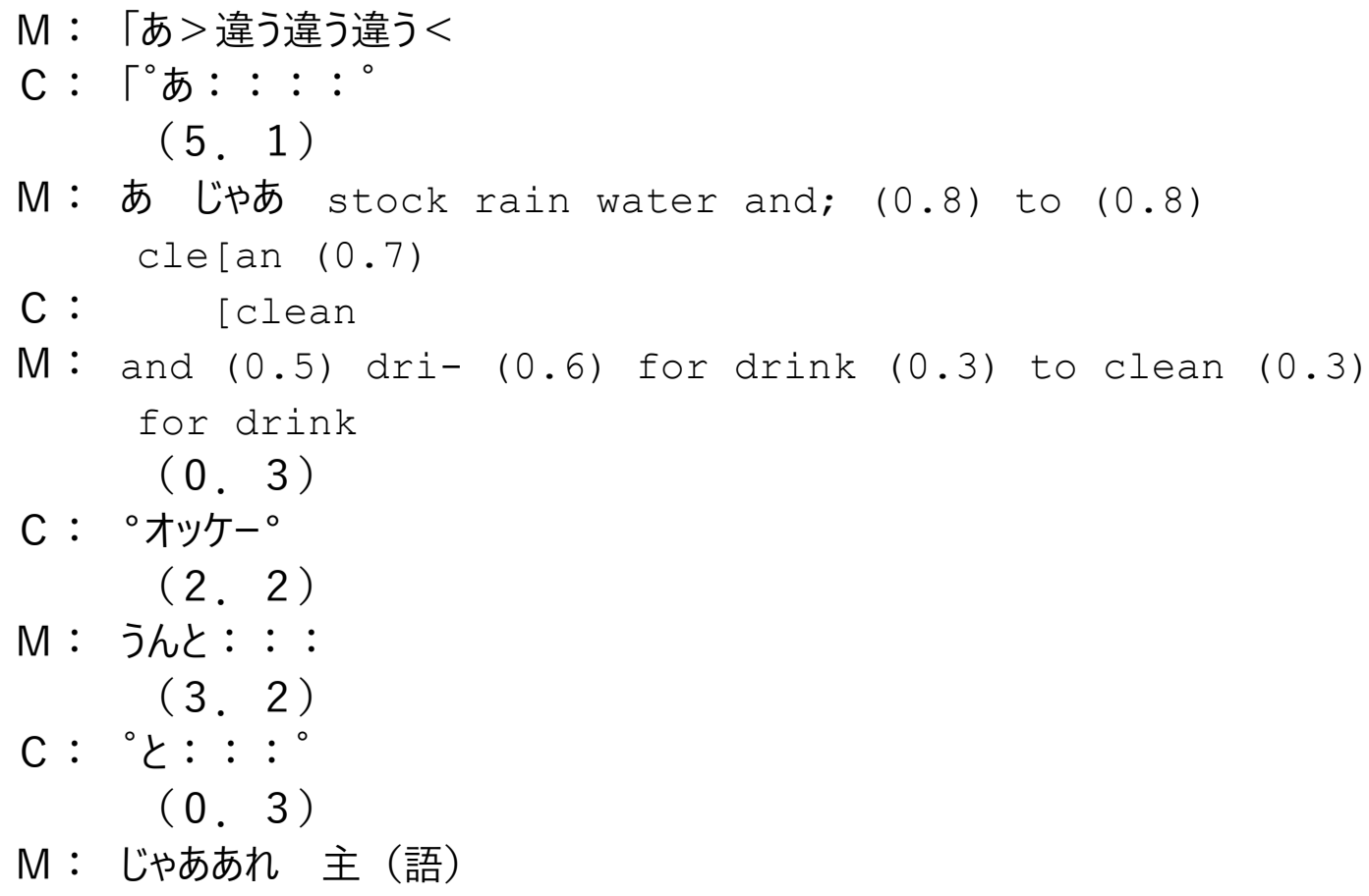




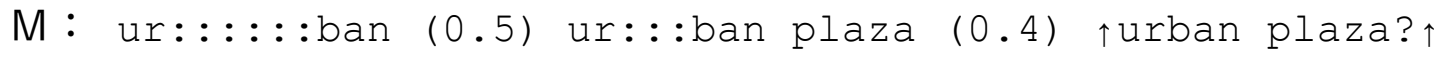

(0.9) u:rban plaza. (0.3) あれあれじゃね；（1．9）>あれも うもういけるよもうできるよく（1.3 ）@うっひや@（1.1)

もうmany people coming: : (1.4) アーバン プラザの近くには

（．）ㅈリリ-（0.3）（（咳払い））（。）ストリ：：：トカーや：

: : (0.7) $\operatorname{MAX}$ (. ) そしてたくさんバス停がある (0.4) スト

リートカーは（．）PSUの 学生証 を持っていれば：学生はみんな無

料で乗れる（0，2）俺らでいうまあ（。） T-

C : - ${ }^{\circ}$ ふふふら ${ }^{\circ}$

$\mathrm{M} ：$ 「何だ $\mathrm{TL}$ 何だ $(0.4) \Gamma$ (あああれな)

C :

「（あれね）

(1. 3 )

$M$ ：君達はどんな方法で通学してる？（0４）`おっ（0，2）これはかん た「んじやない;

C : 「バス

(1. 1)

C : by bu ${ }^{\circ} \mathrm{s}::::^{\circ}$

(0.9)

M： あ フィニッシュだしかもこれ終わったら

(2. 0 )

$\mathrm{M}$ ： notebook (1.3) >あ違う (「ちよちよちよ $)<（ 1 ， 5)$

note five

C :

○「uh huh ${ }^{\circ}$

(4. 8)

$\mathrm{M}:$ we

(2.3)

$\mathrm{M}:$ usually

(5. 8)

M: take (1.1) a bus

(2. 2)

C : ${ }^{\circ}(\quad)^{\circ}(0.8)$ オッケー

(1. 2)

$\mathrm{M}:$ オッケー?

(6. 1)

C : フィニッシュ?잉

(2.5)

M： え：ええ ここ英語？

C: uh hah [hah hah: : : 


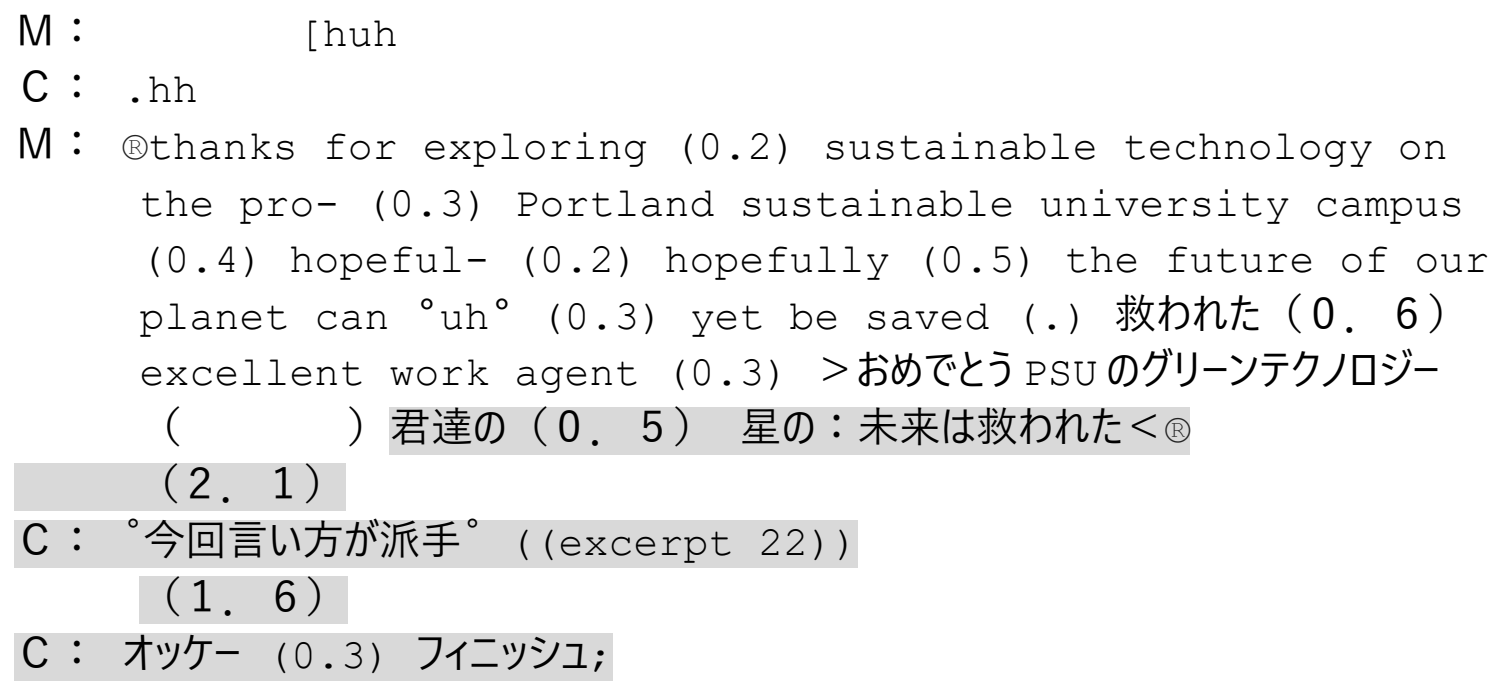

[JAPESLSep072016HC4,14]

The group 1 members speak with the researchers and then head back to the library.

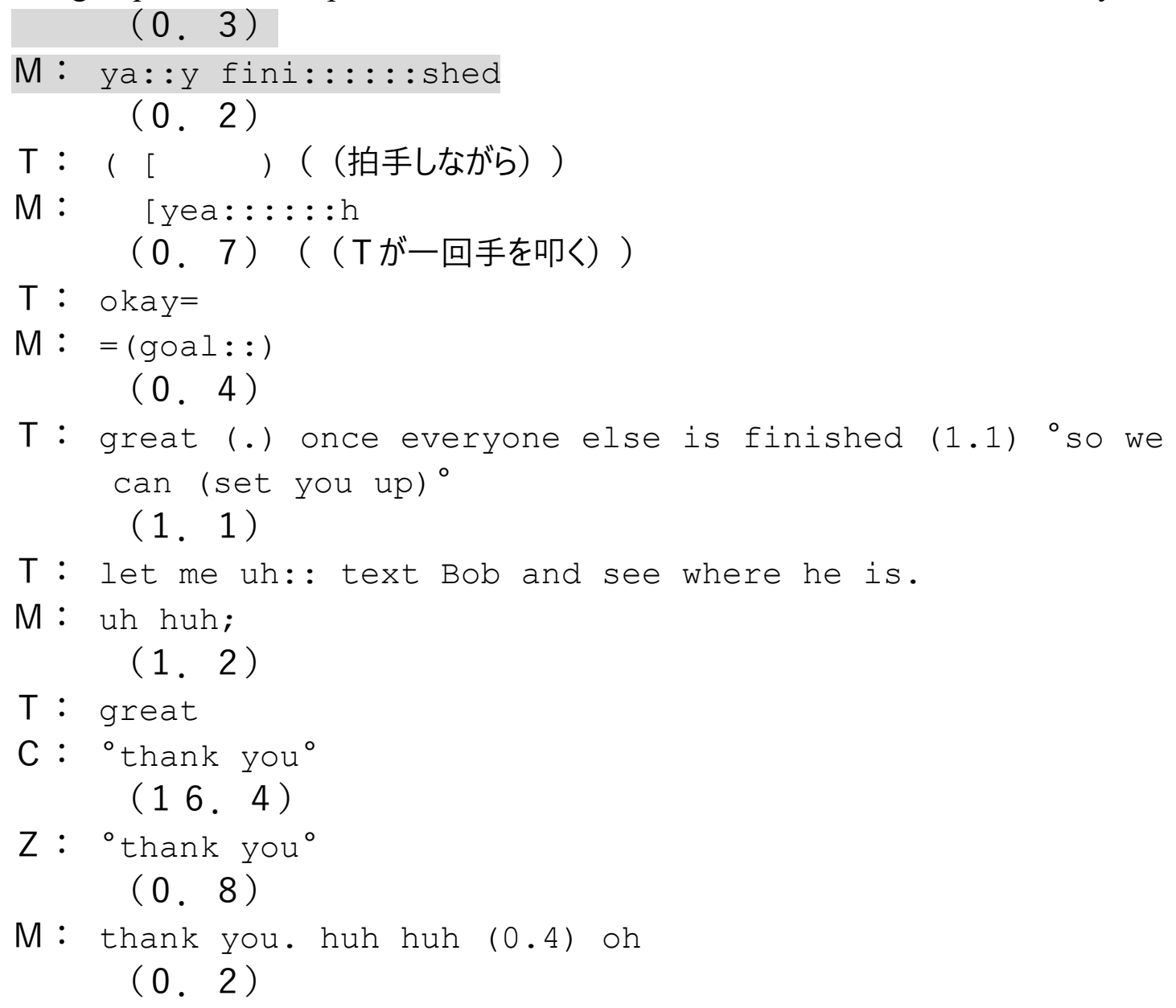




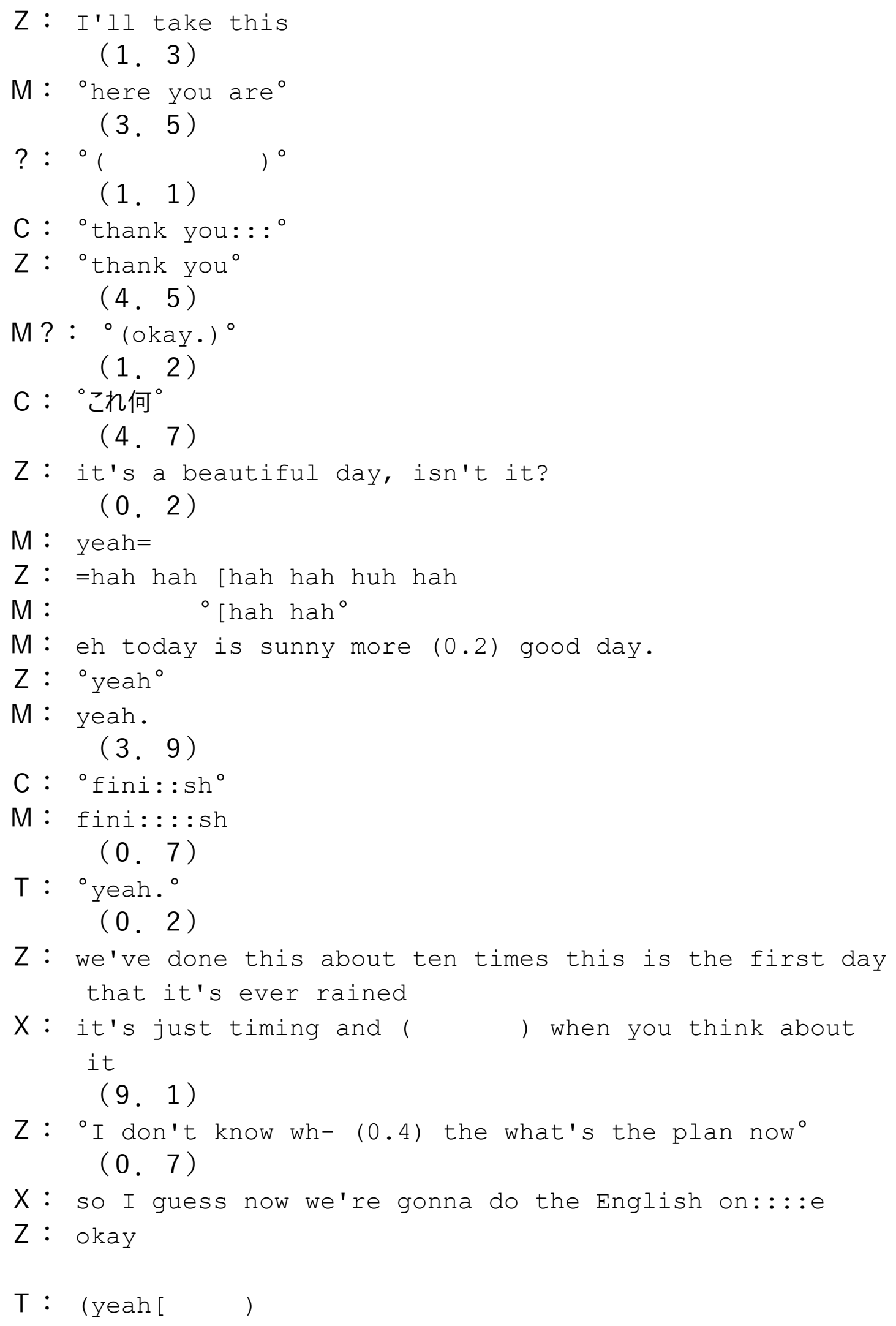


Z : [and I think

(0.3)

$X:$ so in the:: $(0.3)$ in the English version it explicitly tells them ${ }^{\circ}$ (to record it/the audio) ${ }^{\circ}$ (1. 1)

Z : okay

$(0.5)$

$Z:(\quad)$
(0. 8)

X: 'cause that's 'cause they're supposed to the first one was (people could just type it)

Z : yeah

(1. 5 )

$X$ : and so I wonder I (could (1. 3 )

Z : yea: :h (0.2) ${ }^{\circ}$ I would ${ }^{\circ}(1.2)$ I didn't yeah (0.4) so I don't know what (1.4) you know in the instructions for the game? (0.4) in Japanese? (0.4) when it said you find a pla:ce:; and then:. (0.3) it [said to, (0.4) what did it say to do=

M :

․ uh huh ${ }^{\circ}$

$Z:=$ what was the task.

(1. 0 )

$M:$ in Japanese?

Z : yeah

(1. 0$)$

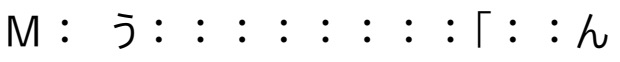

Z: $\quad \quad$ because I think in the English version it $[$ says=

M : $\quad$ [uh huh

$Z:=(1.1)$ make (0.4) [ah:::::(0.7) a report

$\mathrm{M}:$ $\left[{ }^{\circ}\right.$ uh huh $^{\circ}$

M : make $a{ }^{\circ}$ report $^{\circ}(0.5)$ 調査

(1. 8)

Z : yeah

$(0.3)$

$M:{ }^{\circ}$ $「 h^{\circ}$ 


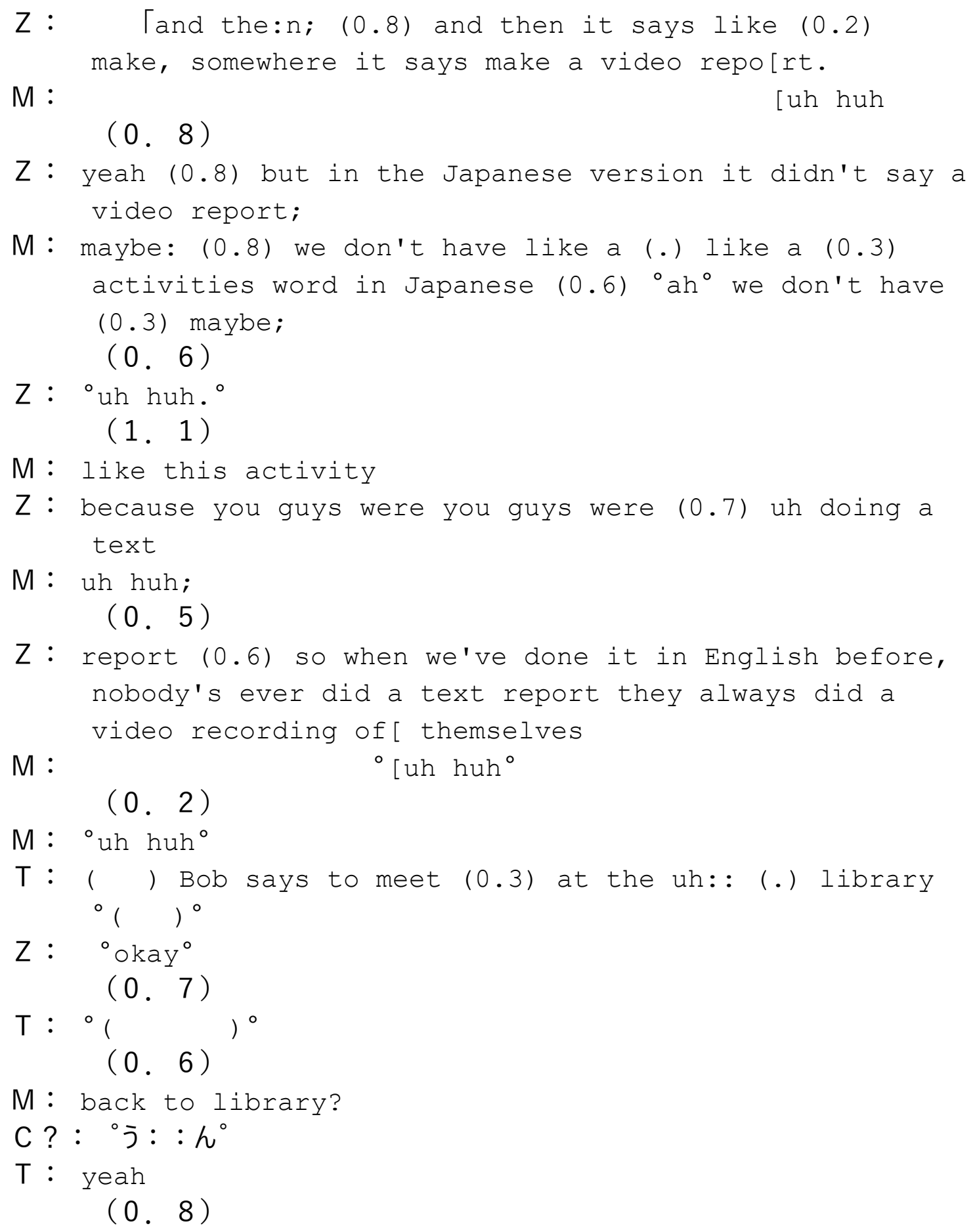

The group 1 members head back to the library while chatting with members of the other groups.

$M: \quad($ (咳払い) $)$ 


$$
\text { (1.0) }
$$

M：みんな雨宿りしてやがる：：。吞気に

$$
\text { (1.8) }
$$

C : 生意気なんだよ゚

$$
\text { (1.0) }
$$

M：何が

$$
\begin{aligned}
& \text { (1.2) } \\
& \text { C : ○みんな（０，3）（ガウディ）。 } \\
& \text { (1.0) } \\
& \mathrm{M} \text { ：あ本当だ } \\
& \text { ( } 10.1 \text { ) } \\
& \mathrm{M} \text { : オッケー? } \\
& \text { (0. 4) } \\
& T \text { : back to the library } \\
& \text { (0. 2) } \\
& M \text { : yeah: : } \\
& \text { (1. } 3 \text { ) } \\
& \mathrm{M} \text { : back to library } \\
& \text { (2. 6) } \\
& (12,6)
\end{aligned}
$$

$\mathrm{M}: \mathrm{hi}$

$$
\text { (0. 2) }
$$

T2: hi; (0.5) how's it going

M: huh huh huh [ (huh)

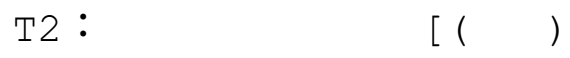

$$
\text { (3. } 2 \text { ) }
$$

C : 。これどれ位の雨だったら決行なんだろうね？

$$
\text { (0.7) }
$$

M： `ね：：あれだこりあ：：>まだまだじやねたぶんく

$$
\text { (0.7) }
$$

T: ${ }^{\circ}\left(\right.$ ) library huh hah hah ${ }^{\circ}$

$\mathrm{M}:$ yeah

$$
\text { (6. 6) }
$$




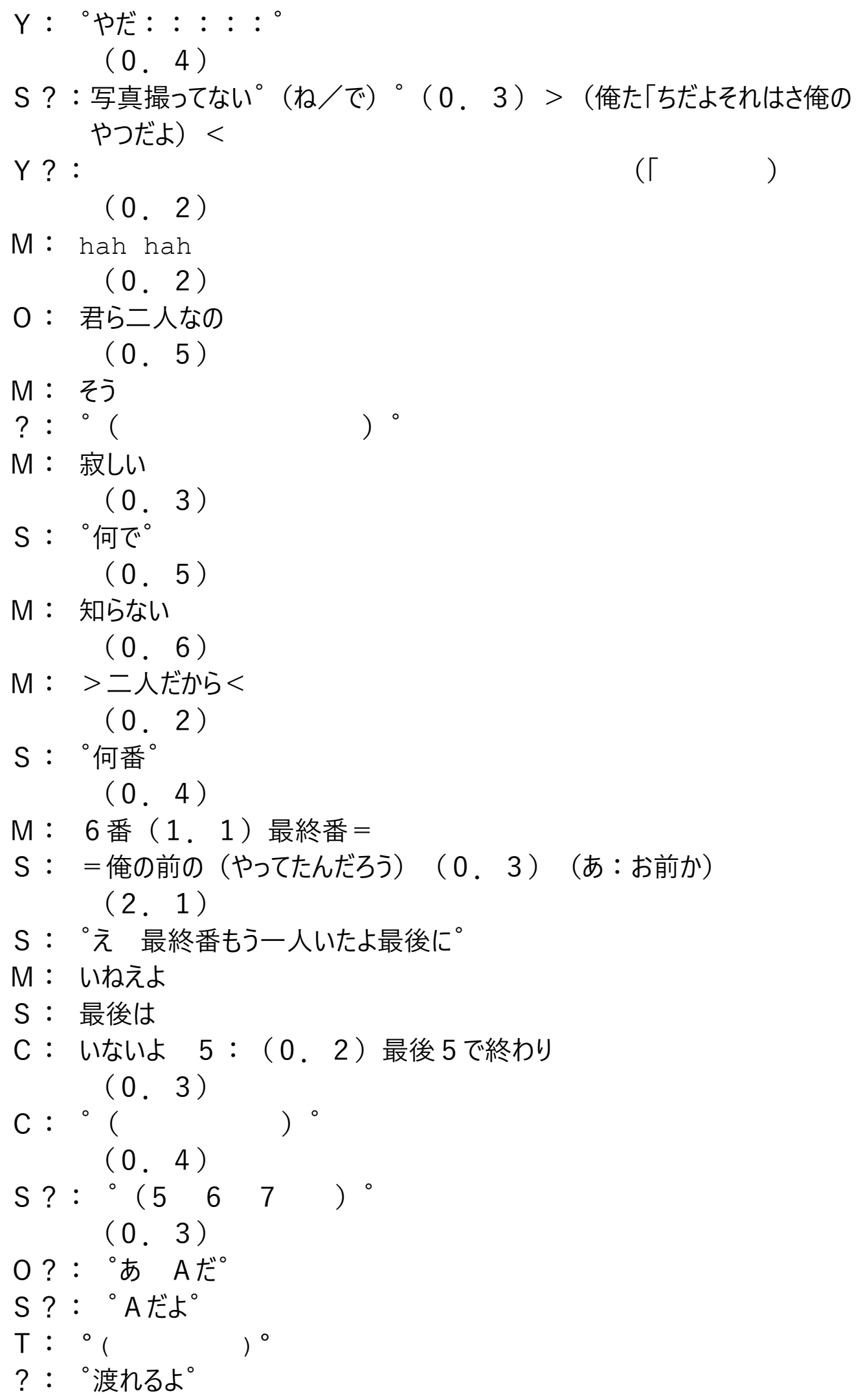


(0.8)

O?: “渡っちやうの

(2.9)

O：みんな渡らないのか

(0.4)

?: ${ }^{\circ}(\text { yeah } / \text { ねえ })^{\circ}$

(2. 3 )

?: ‘ねえ: ${ }^{\circ}$

(0.6)

M：>一応どこまで録画されてんだか分かんねえけどとりあえずきよろきよろ

しとく<

( 0.5 )

O：だ 「こっちじやないよ

Y?: 「ih hih hah hah hah ah .hhh

(0.4)

0 ? : Sちゃん

(1. 1)

O ? : Sちゃんこっちじやないよ

(1.0)

S ? : え?

(0.4)

O ? : フィニッシュこっちじゃ「ないよ
A :
「何「やってんだよお前は：：：：：
$M$ :
「わは .h.h.h hh..h @だって@
（（MがAに向かってカメラでふざけている））
O： フフィニシュこっちじやないよ゚
A： @こっちじゃないよじゃ「ないよ@
0 :
?:
○「違う方向に向かって「（るよ）。
( ( 111,1$))$
○「(違うよ)。
A：`ね：。（）お前やばいぞ>お前く（（．２）キモかったぞお前。 やばかったぞお前「やば いやつだぞ（それ）

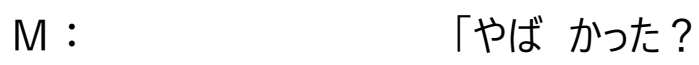
$M ：$ ： ：あく「までほら カメラで撮ってるって体だからら俺が見てるわけ じやないから
A : $(\Gamma \quad)$
「なるほどね
なるほどね。

$$
\text { ( (体=てい) })
$$

$A ：$ 分かった $(0.4)$ それなら納得してー止めてくれ= 
M : =huh huh huh (1.3) 映すぞ

(1. 1)

A : 隠れるぞ

M : huh hah hah

(1.7)

A : あ : みんないた :

(3.3)

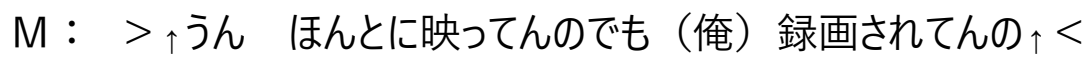

A : あ：（0，2）>録画されてた（さっき見たら）<

(2. 2 )

A：でもね：あれなんだ：（1，0）>何でこんなオレゴン大学でもやったこ とをもう一回やんなきやいけないんだって「いうく

$M ：$

$M ：>$ 今度ビデオバージョンで今度は「：<

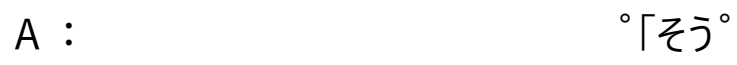

(0.2)

A : > 今度ビデ「オ<

$\mathrm{M}$ ：「しかも何か変な何か：：レコード：：：（0，7）何か：

(0.2) 撮られたりしてるし

$(0.7)$

A：>これあれだよ 単位に関係あるやつく ( 1.0$)$

A : 「これ：：：「「これ 6 単位だよ

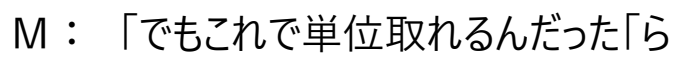

(0.4)

M : huh やば「過ぎだよ 6（0，2）6；

?: $\quad$ 「いやいやいやいや

(7. 3)

[JAPESLSep072016HC4,16]

The group 1 members head back to the library.

?：はい お口開けて：：（1４４）はいお口開けて： :

（（カメラを医者の診察に見立てて遊んでいる））

$M ：=$ 何 そういう「そういうのじゃないたぶんこれ

A : 「huh

(2.5)

$M$ ：映ってんのかな本当に 
(0.3)

K：映ってるんだそれが見え-見えたもん（1３）録画したの

(0.4)

$C: \wedge::::$ :

(0.2)

?: uh huh

(0.2)

$M ：$ 見たいな：

( 0.7 )

M : 地味に

( 11.7 )

M： 赤じやん（1３）ね：ナチュ- >ナチュラルに渡ってんのこの日本人 $<$ 達

(0.5)

?：遅いからよ

(0.5)

$M$ : ffhah

(0.3)

?: huh [hah hah hah

M : [hah hah hah

(26.4)

D : これさ： :

$\mathrm{M}:$ j: : ん;

(1. 1$)$

D : 開くだけで電源つくんだね

(0.6)

$\mathrm{M}:$ ほうえ：：：：：

D : （閉）じるだけでさ：：：（0，3）これ

(0.4)

M：.hh （．）「本当だ

D ? :

(「あ)

(1. 3)

$M ?:{ }^{\circ}$ ふら

A：。ささすがに俺そういうのはあの：：`あれが（．）働くんだ (0.4)

M : ah hah hah ${ }^{\circ}$ ah hah $\left[\right.$ ah hah ${ }^{\circ}>$ @あれが働くんだ@< $?$ :

$(0.5)$ 


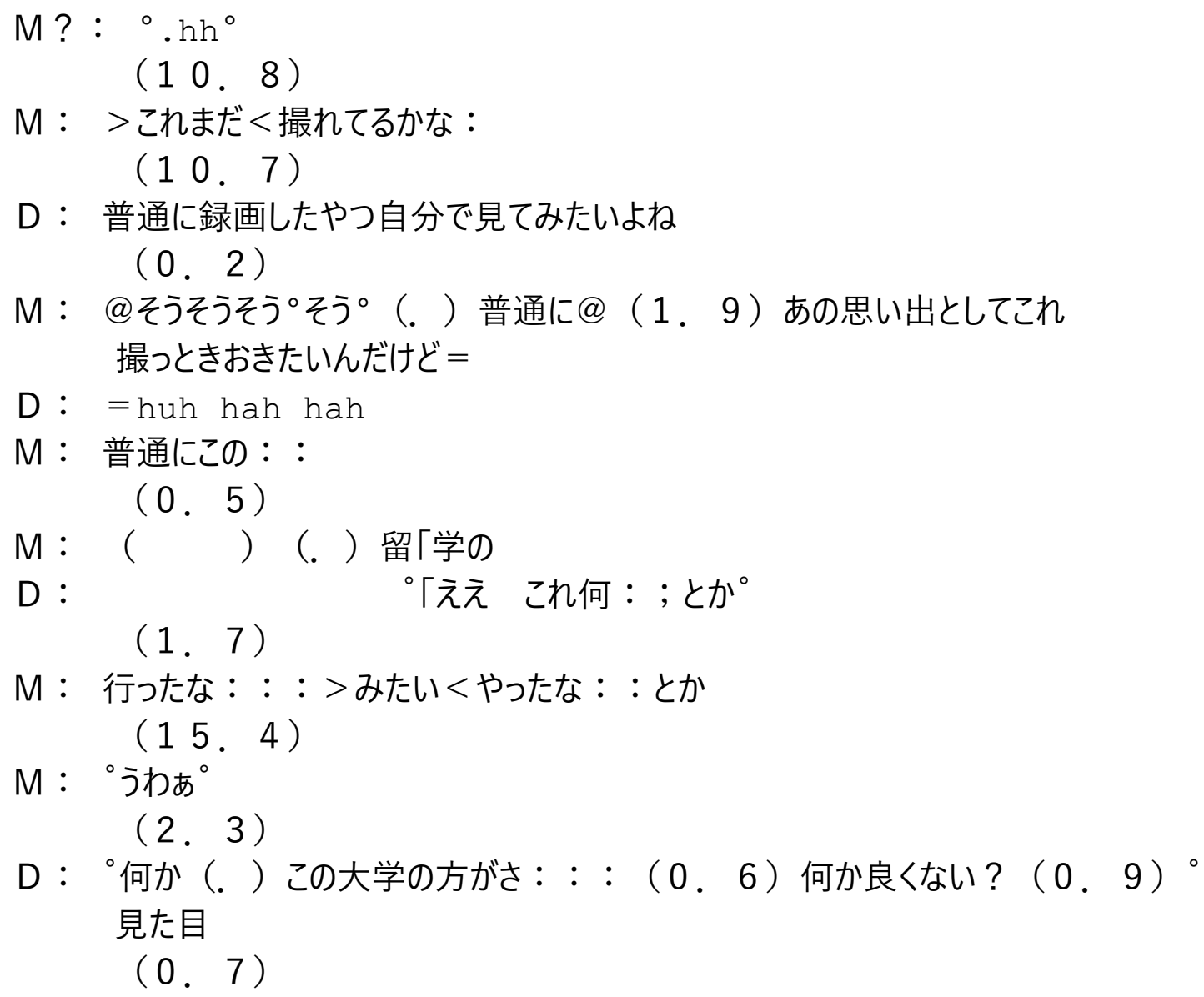

M : まあ見た目はね

(3.6)

M : >あの (多摩学) と青学に : : $(0.8)$ 青学に行った やつ $\left(\Gamma^{\circ}\right.$ いるな $\left.{ }^{\circ}\right)<$

D : $\quad \Gamma^{\circ}$ ah hah @青学 出た@ ${ }^{\circ}$

(（日本の東京にある多摩大学と青山学院大学の事？））

(1.4)

D ： あの青学訪問は結構謎だったけど「ね

$\mathrm{M}$ :

「うんうん huh hah hah hah

$$
\text { (0.9) }
$$

M：何 何で（. ）青学行ったんだっけ あ：：>違う<

$$
\text { (0.4) }
$$

$\mathrm{D}:$ そうあ「の

） こっちのあの（E L ）

$M: \quad=>\Gamma$ 違うく表参道行ったからか

$\mathrm{M}$ : そうそう

D：あれで

$$
\text { (0.7) }
$$




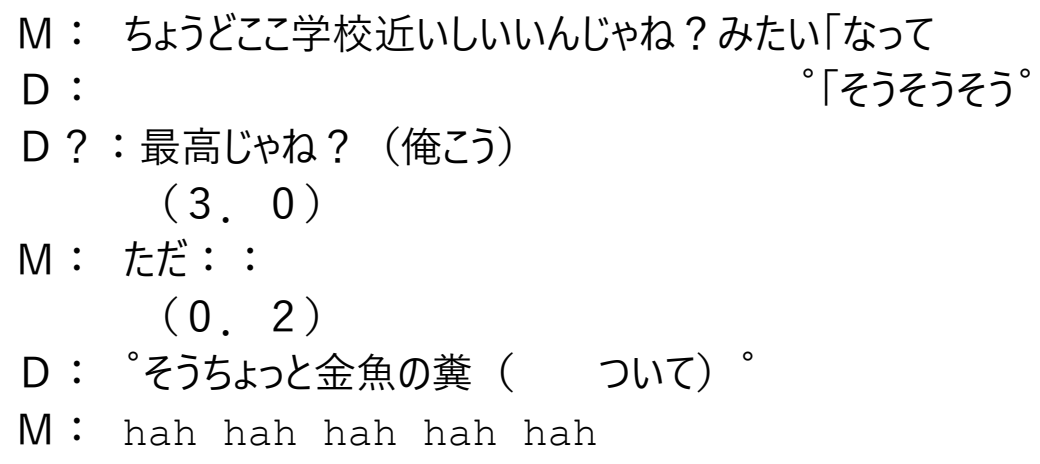

(1. 3 )

D： ○あの：（急に）あの友達との（再会を果たし）。

$(0.7)$

$\mathrm{D}$ ：俺は：：：：（堅実派）なのに何やってるんだろうと思いなが「ら

$$
\text { (（堅 = sounds like ぜん） }
$$

M :

$$
\text { ( } 0.5 \text { ) }
$$

$\mathrm{M}$ ：>それな君に関しては@何しに来た本当に何しに来たみたいな@く
（ 0.5) 何も得るものがなかったっていう
(0.9)

[JAPESLSep072016RC1.5]

Group 1 plays the second iteration of the AR game with English text.

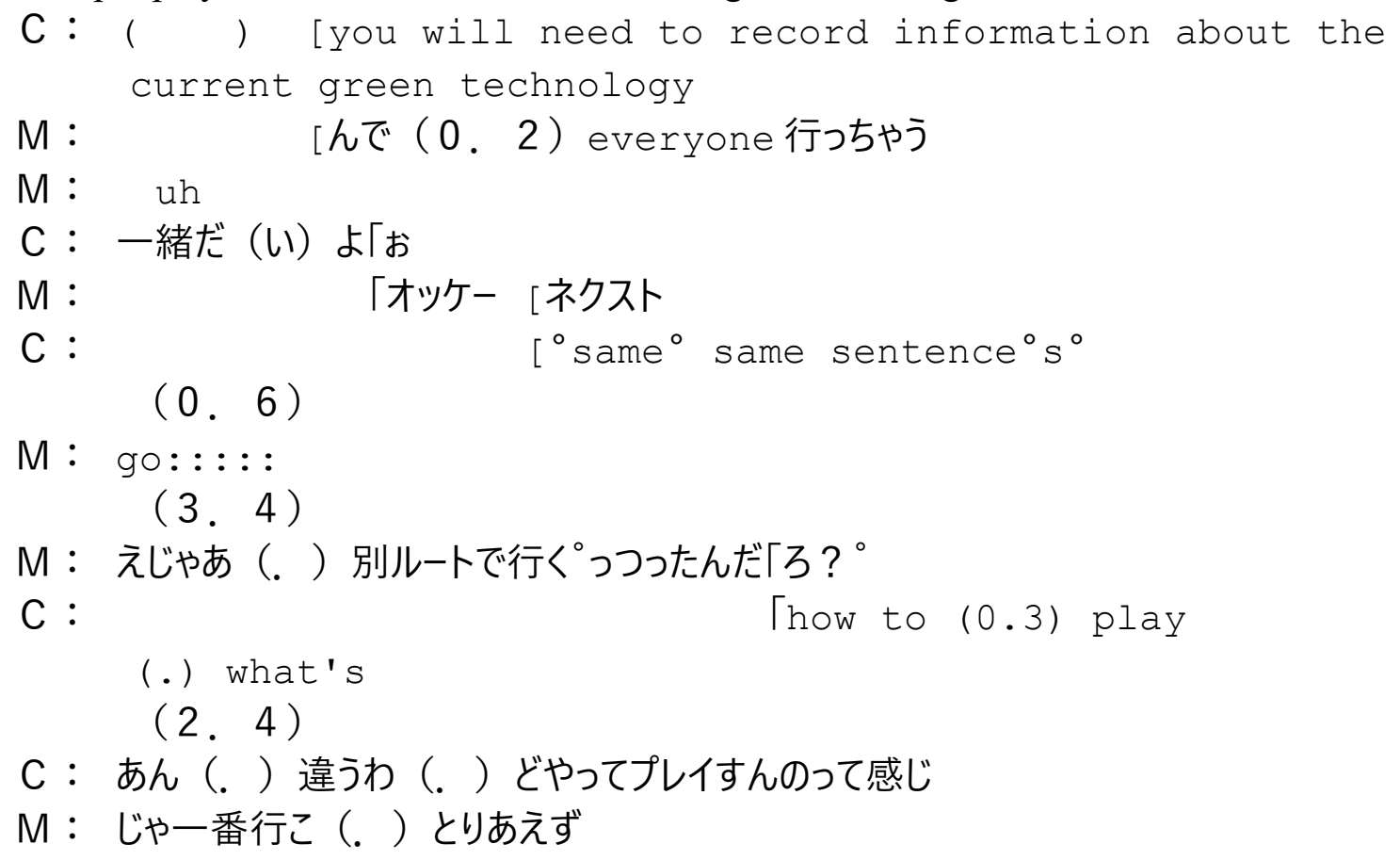


(0. 6)

C : さっき（そ）同じだよ（０３）つま：んない

(1.8)

$\mathrm{M}$ ：お前（．）それ録音されてるんだから「な

C : $\quad$ 「はっはっ $(0.2) \circ \mathrm{h} \mathrm{h} \mathrm{h}$

(1.4)

C : @。あ(0.2) は「っ@(0.4)あ：：：：：：：。

$\mathrm{M}$ ： $\quad{ }^{\circ}$ あ 録音 $(0.4)$ お前すごい（）

とんでもないこと言ってるけどこれ録音されてるんだからな（1，2）

つまんなとか言ってるけど

(2.5)

$M:$ ：めっ（）ちゃ楽しいやん（．）これ((0:42))

(4.1)

$M$ : very interestingですや：：ん((0:48))

(1.2)

C : ○どんだけ雨に濡れ（らせるんだ）。

(0.9)

$M ：$ “あ”俺もフードをかぶりたい

(3.8)

C : まさか 3 回目ドイツ語とかやんない゚よね？

。え (. ) 笑って $(0.2) よ:: ~: 「::(0.3) 。 \mathrm{~h} \mathrm{~h} \mathrm{~h} \mathrm{~h}$

$\mathrm{M}:$

$\lceil\mathrm{h}$ 。

C : @笑っ $(0.2)$ て「よ：：：：：@

M : 「ぬんちゃってぬん（. ）ちょっと俺何が面白いポイント だったか 分かんなくっ「て

C： $\quad$ 「。hhhhhもお：：：：：：：：：

(0.4)

$M ：$ 受け-受けポイントが今分かんなかった

(0.5)

$C:{ }^{\circ}$ 今の $(0.7)$ これは $(0.7)$ 受け゚

(5. 1)

C: ${ }^{\circ}$ (Neuberger) bike parking ${ }^{\circ}$ ((excerpt 27))

$\mathrm{M}:$ オッケー

(0.7)

$C:{ }^{\circ} え \supset^{\circ}$

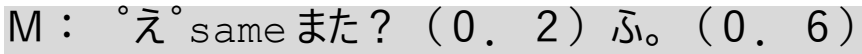

バイク@バイ（0４４）バイクパーキング；@

C: ${ }^{\circ} j h^{\circ}$ 


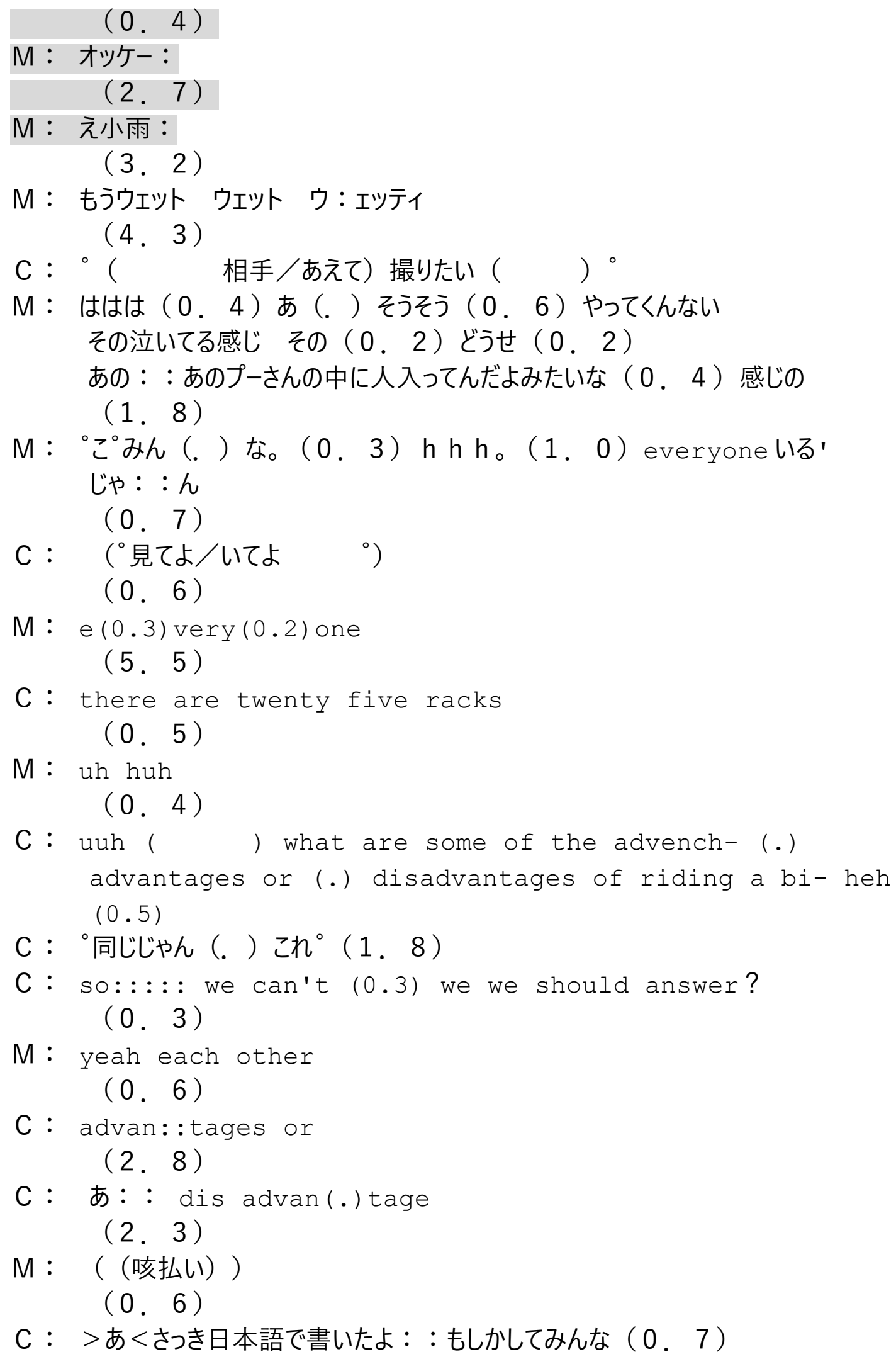




\section{違うよね？}

(0.5)

M：うん英語で入れた (2，1) note one

（2．5）（（Mの鼻をすする音））

$\mathrm{M}$ : advantage (1.1) is

(6. 0 )

C : advan(.) tage

(4.9)

$\mathrm{M}:{ }^{\circ}$ あの

C：（選んで）。って゚どっちだっけ？

(0.8)

M： いや普通にいいメリットだけど（０．３）アドバンテージだから

(0.5) this advan- (.)で (0.6) あ:の: (0.1)

交通機関使わないから：：（０１）トラフィック トランスポー

(0.2) テーション使わないから：：(0.1) h : : ?

>合ってる ; トランスポーテーシショ゚トラフィック トランスポーテー

ション?<

(0.5)

C : トラフイッー

$M ：$ 英語合ってる?

(0.4)

C : 英文（0３）つてトランスポート?

(0.8)

$\mathrm{M}:$ j

( 0.6$)$

C : (で: : しょ: : : : ?)

(1. 5 )

M: transportation? (0.2) traffic tra[nsportation?

C :

[uh huh

C: uh huh

(0.2)

$\mathrm{M}:$ h:?

$(0.8)$

$\mathrm{M}$ : po-

(0.4)

$M:$ [ ahuh. @

C: [transports: : : : : ?

(0.5) 


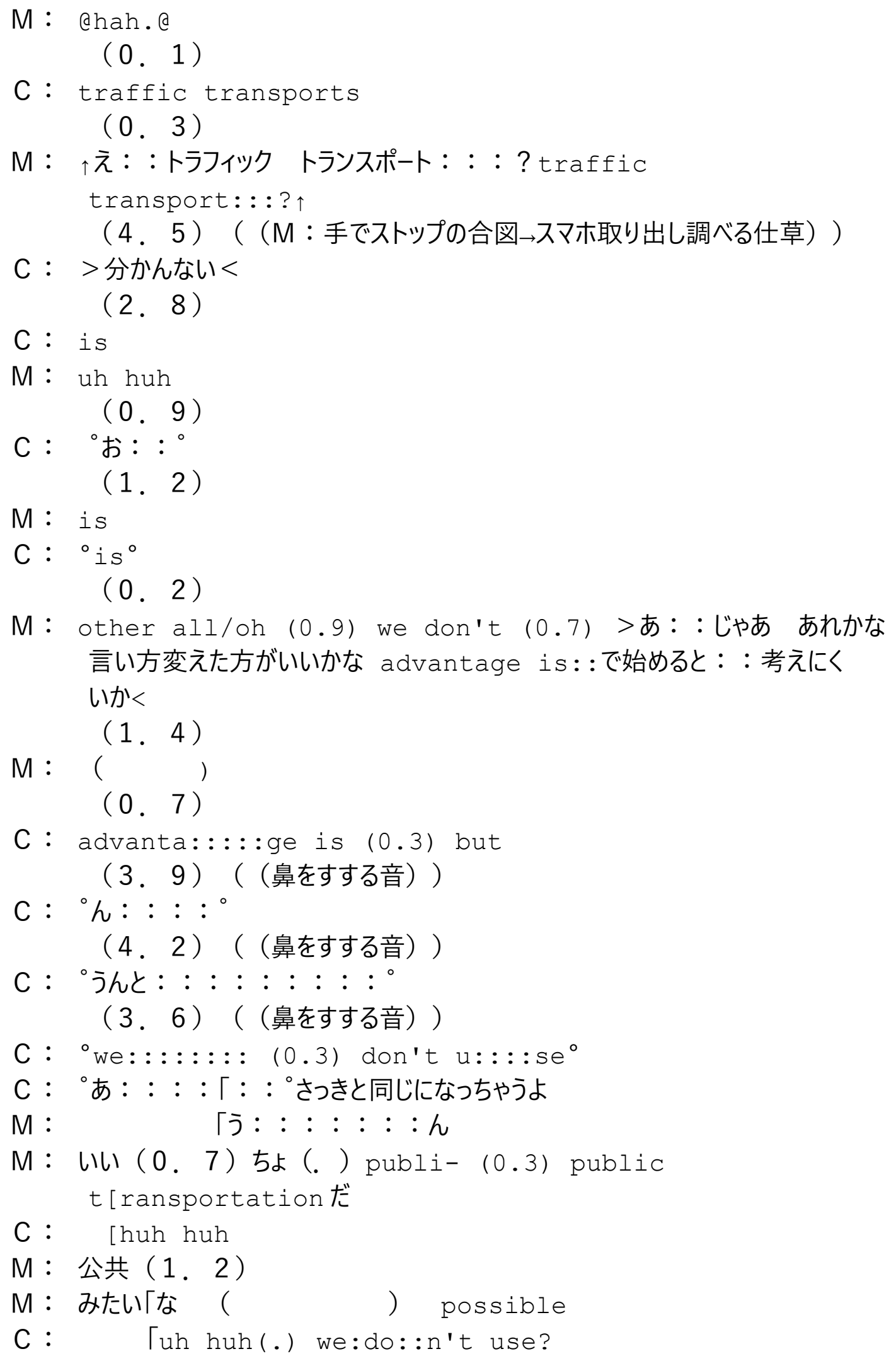




\section{(1.9)}

$\mathrm{M} ：$ パブリック?

(5.4)

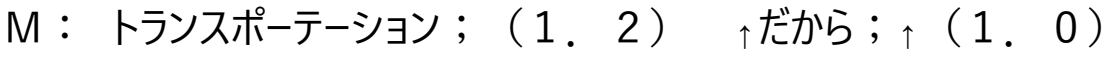

ま（．）結局はその：排出しないよねって話

(1. 0$)$

M : [emi emit（．）しないよねって

C : [so/そう（．）（だよね）

(0. 9)

$M:$ と: so:: : (0.5) we don't (0.3) emit (1.2) みたいな

$(0.3)$

C: so: : : : [::::::::

M ：［あ さっきよりは文が長くて何かしっかりしたこと書いてるよ

$::$ :

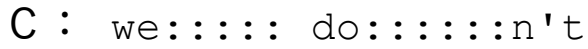

$M:$ と [we don't: emit:: :

C : $\quad[(($ 咳払い $))$

(1. 3 )

C : emit

(0.4)

$M$ : dio carbon dio[xide

C : [( (咳払い) $)$ そうだ

(0.7)

M: car (0.2) bo:::::n (0.2) dioxi::: [:: de

C : $\quad\left[{ }^{\circ}\right.$ Carbon $^{\circ}$

(1. 7)

C : ${ }^{\circ} d i(.) \circ() x i.(). d e^{\circ}(1.1)^{\circ}$ で $^{\circ}$

(2. 3)

M：で：：：disadvantageがなんだっけ？

$(0.6)$

C : （で） (1.6) dioxideつってこれ（0．3）て>それは<あれ？

(0. 2) $\quad c::$ ?

(2.7)

C : cいる？（0，3）よね？（0，2）どっかに

(1.3)

$\mathrm{M} ：$ ダイオキスゥ：：：

(0.4)

$C: \uparrow う::: ? \uparrow$ 


\section{(1.9)}

$\mathrm{M}:$ は。

(1.5)

C : （いっつ）これで合ってると思ったんだけど 赤線出てきた (1.9)

M：あ（．）んじやメリット考えといて（0．３）あの: : thisあ じやあ: : :「デメリットか di- disadvantage

C : $\quad \quad{ }^{\circ}$ disad: : : ${ }^{\circ}$

(1. 6)

C: vantage is

(2. 2)

$\mathrm{M}:$ disadvan[tage is?

C : $\quad[(($ 咳払い $))$

(0.5)

M : >ほらもうみんな行っちやったよく（0，3）ha. (0.5)

C : みん（な）さあ（1，4）。まあいいや。

(1.4)

M： え俺ら遅いチームみたくなってるよ（1，0）

M: dioxideね (1.6) di:::(.)०:::xi::::::

(2.7)

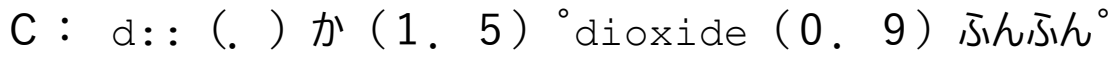
(2. 4)

C: disadvantage that::::(.. ${ }^{\circ}()^{\circ}$

(1. 4$)$

$M: j:::: ん$

(3. 3 )

C : あの : : :

(0.7)

C : only twenty. efived (0.6) .hhhhh (.) もお: : : : : : 思いつかな：：：い（0，3）だって事故に遭うは言ったじやん？

(0.6)

M : >いいんじやない<（0，2） sameでも？ ( (excerpt 26))

C : ${ }^{\circ}$ sameでいいっか。 $(0.7)$ じやあ：：

(4. 0)

C: we:

C: ${ }^{\circ}(4.5)$ 


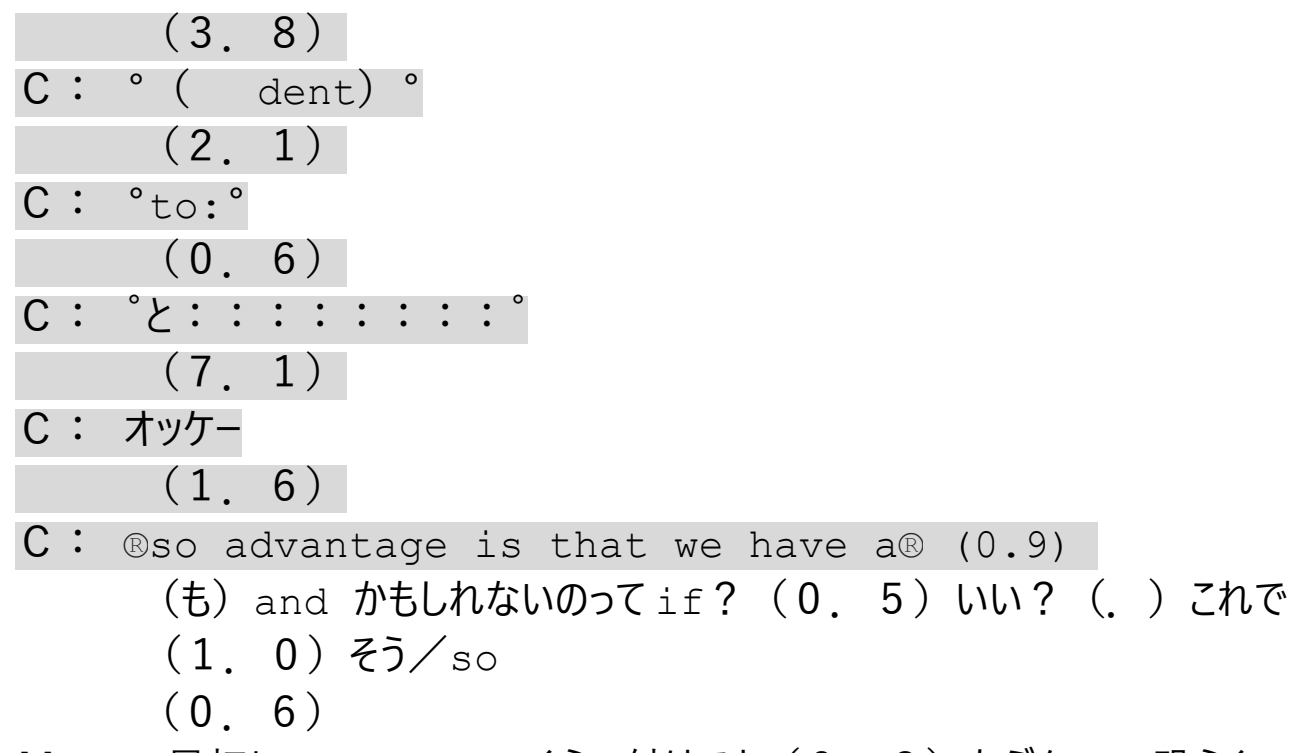

M：＞最初に<probably<゙らい付けてよ $(0.2)$ たぶん：：恐らく： みたいな意味で

(3.2)

M： ○ん゚あるいは（．）じやあpossibility（とか）（1．0） there is possibility: :; (0.8) とか $(0.2)$ もありじやん（0. 6）そういう可能性が（あるじやん）（1，2）短いしね (0.9)

C : えつ逆?

$(0.8)$

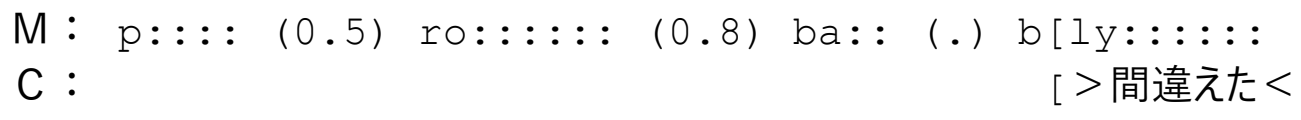

(2. 3$)$

C : > 合ってる ?<

(0.8)

$\mathrm{M}:>$ 知らね $<$

(0.7)

C : どっ「ちかこれ逆だ

M : 「違った：：：（0.2）ha.

(2. 6)

$M:$ library (

(0.9)

C : ${ }^{\circ}$ probably; ${ }^{\circ}$

(3. 8)

M : >いいんじやない ? <

C: ${ }^{\circ}$ huh huh $(0.3) \mathrm{go}^{\circ}$ 


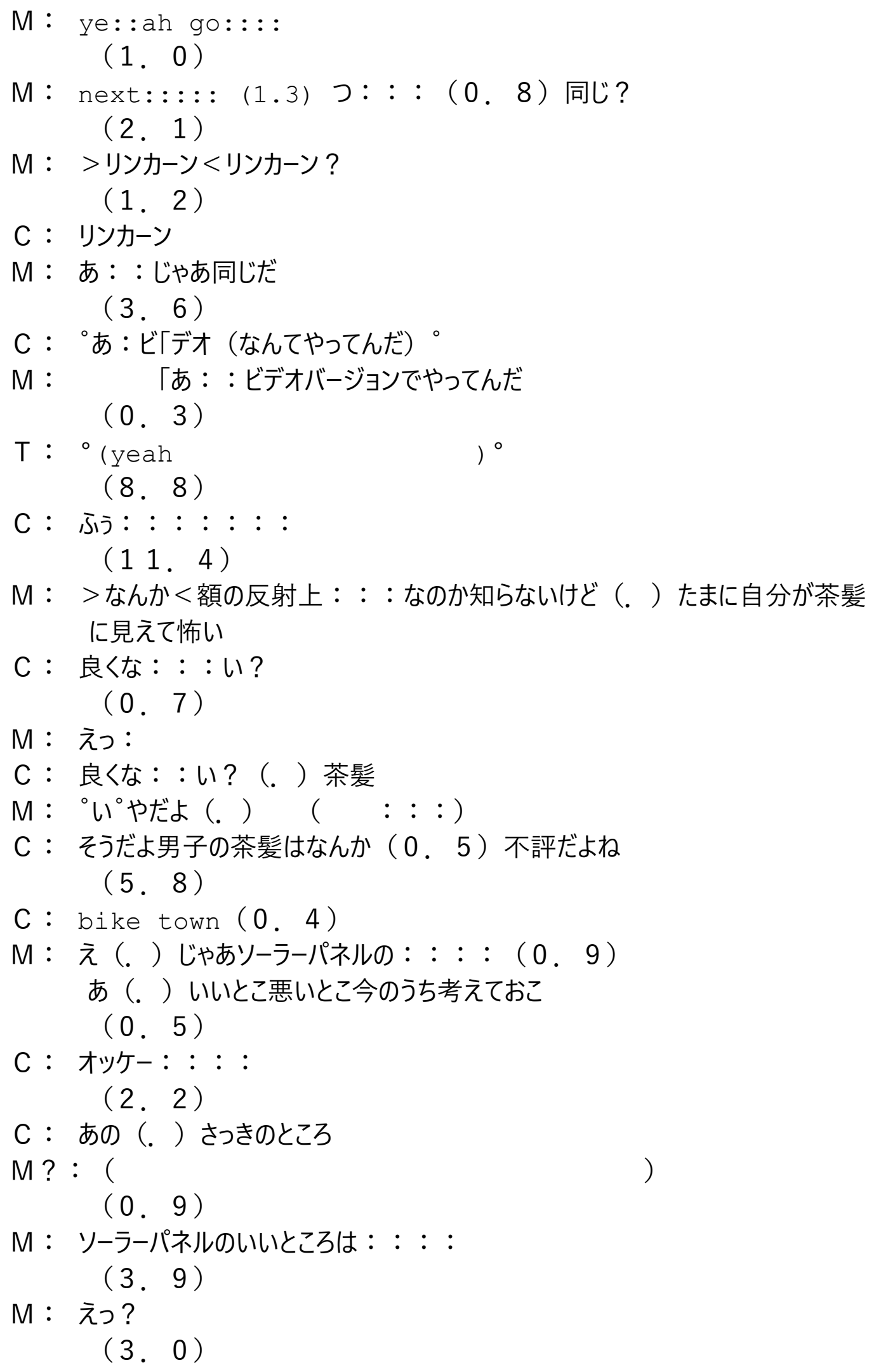


M：急に?

$(0.7)$
C: I likes NIKE
$(0.4)$

T: ah hah [hah

M : [あ：：：

(0. 2)

T: why don't you go to the NIKE store:

C: yeah

T ? : huh huh

(8. 1)

$\mathrm{M} ：$ で（. ） ソーラーパネルのいいところは；

(1.3)

C : え: : : : :と: : : : (1.8)あの：：：：：（1.3）

あ（。）あの：：：（0４４）デメリットは思い付いたよ（。）あの「ね

M :

(0. 6)

C : not あの rainy is not

M：あ：：：：：確かに（0.3） clou(.)dyとか（. ）

clou : :dy か rainy かのときは使えない

(0.2)

$C:$ yeah

( 0.3$)$

M：yeah: : : : (0.4) じやあね：：：(1.5 5 ) あ：の：

(1.7)

$\mathrm{M}: \quad(\xi \Gamma \quad$ )

C : $\quad$ 「ええと

(3. 0$)$

$\mathrm{M}$ ： 蓄えてとくことできない（０．4）できないかそれは (1.5)

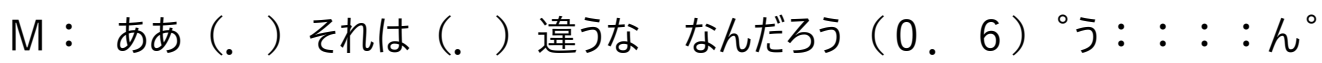
(1.1)

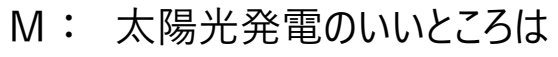

(2.5)

$\mathrm{M}:$ j:::::::::h

$(4.3)$

$M ：$ j: : : : ん 何だろう？（0，7）さっきと同じことしか思い付かない んだけど 
(1. 0$)$

C: (advantage is)

(6. 2)

C : <advantage>

(3. 9)

$C:{ }^{\circ}$ (what is this?) ${ }^{\circ}$

(3.5)

M： 何だろう

(1.9)

C: advantage i[s

M：_[まじでさっきと同じことしか思い付かねえ

(4.5)

$M$ ： 電気を使わない以外に

(2.4)

$\mathrm{M}:$ え: : : : : :

(3. 0$)$

C : disadvantage

(0.5)

$M ：$ 先書いといて

(0.6)

C : $a() d:.::::$

(1.0)

$M ：$ え：：：何だろう？=

$C:$ =vantage $(1.9)$ is

(3. 1)

C: ${ }^{\circ}$ (is) ${ }^{\circ}$

(0.4)

M : char: : :ge

(2. 7)

C: ${ }^{\circ}$ disadvantage is tha: : : ::::t $(0.7)()^{\circ}$

(2. 4)

$C:{ }^{\circ}$ it $(0.4)$ it is ${ }^{\circ}$

(4.6)

$C:{ }^{\circ}$ (これは $)^{\circ}$

(1. 1)

$\mathrm{C}:{ }^{\circ} \mathrm{C}:: \mathrm{lo}_{\mathrm{O}}: \mathrm{u}: \mathrm{dy}::{ }^{\circ}$

(2. 7 )

$\mathrm{M}:{ }^{\circ}$ j: : : : : : : : : : 
(1. 0$)$

$C:{ }^{\circ}(d i(0.6) d)^{\circ}$

(1. 4 )

$M:$ う: : : : : : : : : ん ちと待って ちと待って ちょっと待ってね：

$:(0.3) \circ \mathrm{h} \mathrm{h} \mathrm{h}$

(1. 1)

$M$ : wait wait wait

(7.9)

$\mathrm{M}$ : あ (0.2) あ

(2.6)

$M ：$ 電気使わないから：：（0４）お金が節約で（．） save money save money

(1. 8)

[JAPESLSep072016RC1.6]

Group 1 continues their second playthrough of the AR game from location 2.

C: saving moneyでいい?

(1. 7 )

$\mathrm{M}$ : （（咳払い））（1，3）（だ/じや）ま（．）sa.ving moneyで いいよ

(0.3)

C : ${ }^{\circ}$ huh huh ${ }^{\circ}$

(4.7)

M：まあ或いはwe don't (0.4) waste moneyでもいいけど（） つい

（）あの余計な（）しないみたいな

(3. 1)

C: disadvantage is that the (0.2) it is raining or (.) cloudy? ( (excerpt 32))

$\mathrm{M}:$ jh

(0.3)

C : it (0.9) 何：：?

$M$ : it doesn't work

(0.3)

C：あ（.）それそれ（.）それが言いたかった

(1.9)

C : えっとisn't

(0.9)

M：留めておけ（．）めっちや使えるここ 


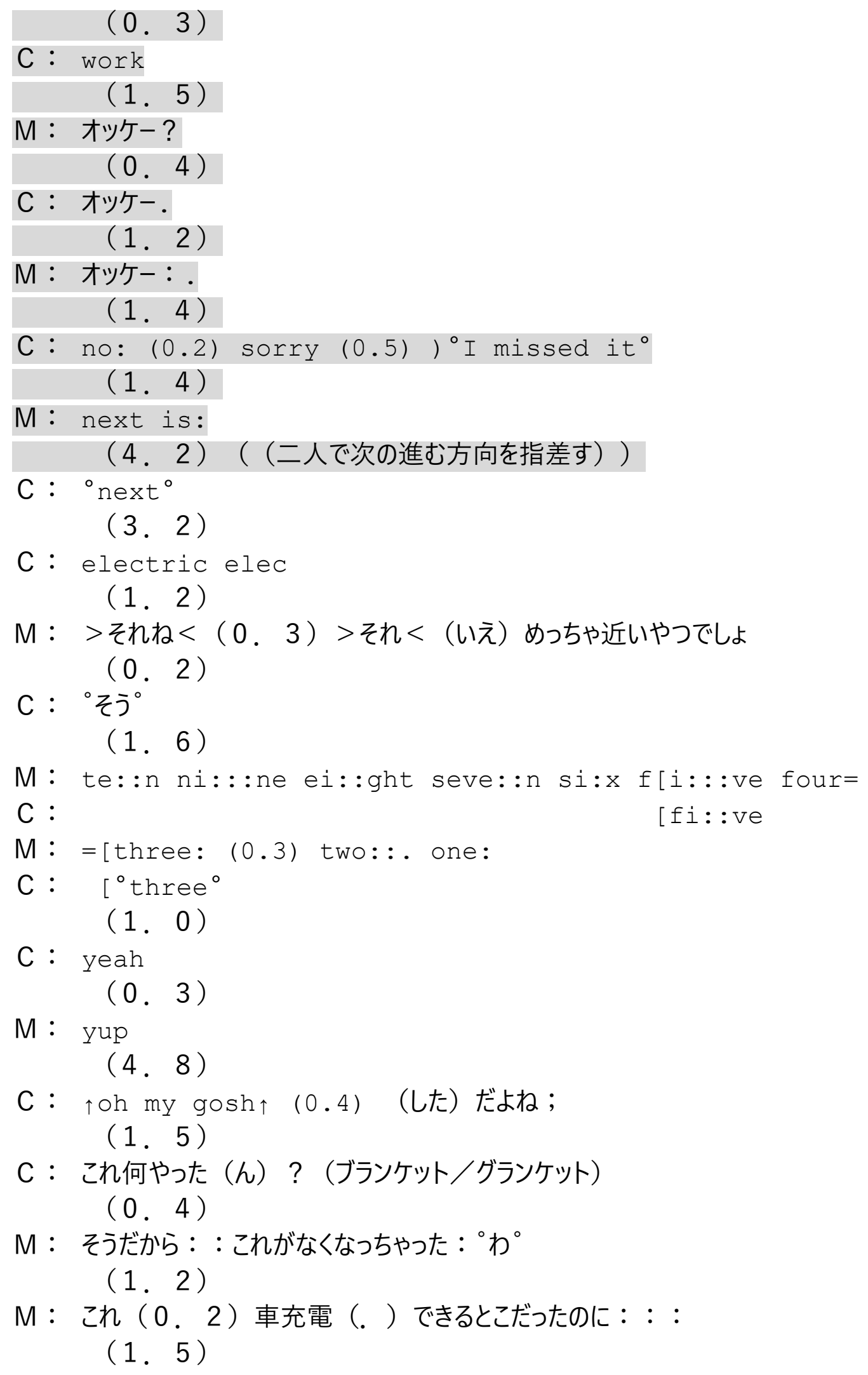




\section{C：やばい（. ）寒くなってきた（。）何か浸透してきた}

(0.7)

M：速くね？（1，2）やっぱNikeだか >らくな：：

$$
\begin{aligned}
& \text { C: } \quad(0.6) \\
& \text { (1. } 0) \\
& \text { (1. 3) } \\
& \text { (2. } 5 \text { ) }
\end{aligned}
$$

M：あ「なたの考え（．）あなたの考えを何つって

$M ：$ この建物どうなっちゃうのみたいな

(8. 2)

C : (electric) (2.6) is (2.0) changed え?なんで?

(5. 9)

$M:$ (great)

C： changeってこれでないっけ？（0８） ${ }^{\circ}$ スペル゚

M : チャングだよ

(1.4)

M : チュ : : : : : : : : : : : :ソ: : : : : : :ジ

C：合ってるよね? ${ }^{\circ}$ でも

$\mathrm{M}$ : あ

$$
\text { (2.4) }
$$

$$
\text { (0.4) }
$$

C：何か違う？

$$
\text { (1.0) }
$$

$M$ : it is

$$
\text { (2. 1) }
$$

M： changed（0．2） 本当だ何が違うんだろう

$$
\left.C:{ }^{(1 .} 4\right)
$$

M : it is change つていう表現がまずおかしいって言いたいのかな

$$
\text { (1.7) }
$$

C：え：：：何でいいじやん（0.3) これは change (0.3) the building is（0，6） おんなじだと思うけどね：：：

$$
\text { (1.9) }
$$

C : 〈そ 
(1. 6)

M：口悪い：：：？録音されてるんだよ：：

(0.9)

C : @それもね@

$\mathrm{M}$ : uh.

(1. 3)

C : ${ }^{\circ}$ あ: : ${ }^{\circ}$

M : C「の悪いところが

C : 「@huh huh@ ブルドッグって .hhh 変換された

$\mathrm{M}:$ hh: : : : ?

C : ブ : : : : :ル: : : : :

$\mathrm{M}$ ：ビュユルディングだよ

（1．０）ビルディング（．）あの綴り違うよ

( 0.7 )

C：違う?

$\mathrm{M}$ : ビイユルディング $\mathrm{b}: \mathrm{u}:$ ね

$\mathrm{C}$ : あ $\mathrm{b}::$ : あ オッケー

(2.3)

$M ：$ ほ ：：：（1，2）英語力（ツボなってるよ）

C : ビユルディングゥ?

(4.1)

C：違う?

(1. 6)

M : b u i hh. ビィユルデ「ィ

C : 「エル エル

$\mathrm{M}: \mathrm{b}$ u (.) i $1 \mathrm{~d}$ かあ

C：エ：：ル1個いらないんだ

$M ：$ ブゥールディングになっちゃうよ

(1.8)

M：いいんじゃない？はあ？もういいよ もう無視「しよう

C : $\quad \Gamma^{\circ}$

(5. 0$)$

$M ：{ }^{\circ} \overbrace{}^{\circ}$ 何て打ち「たいの てか 何て言いたいの

C : [ah: : : building is tend

(0.9)

M： i [s charge って言うと（．）変えればいいのか 変えられるか

C: $\quad\left[{ }^{\circ}\right.$ new $^{\circ}$

C : new 


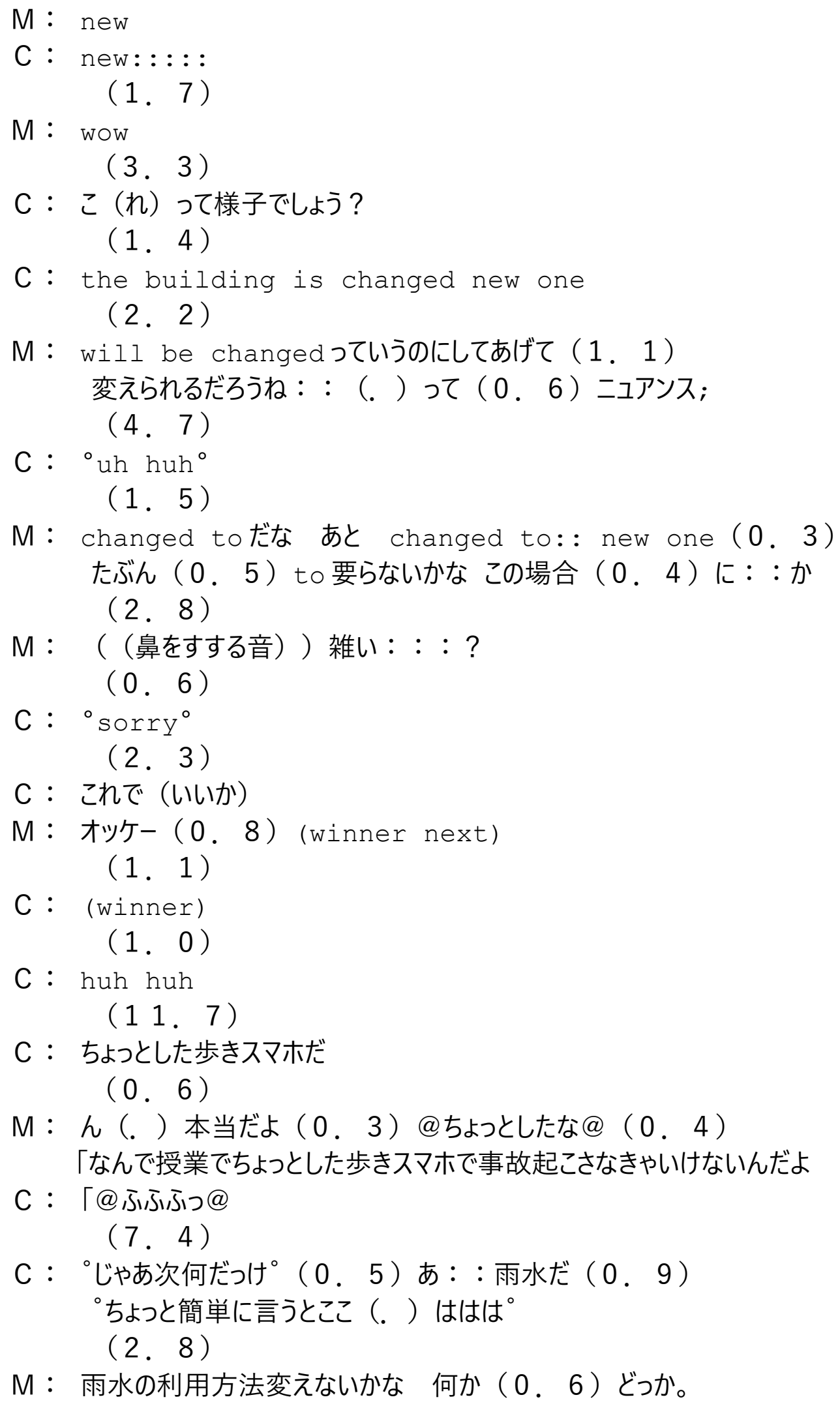

$\mathrm{M}$ ：雨水の利用方法変えないかな 何か $(0.6)$ どっか。 
@ 飲水って正直ちょつと微妙だから：：@

$$
\text { (6.3) }
$$

$\mathrm{M}:$ j: : : : : h

(2. 8)

$\mathrm{M}$ ：あれじやん雨水だったら別にさ、（）取っとけばさ：（，6）

>あの植物にあげればいいじやん別に ( . ) 俺「らが飲まなくていいからく

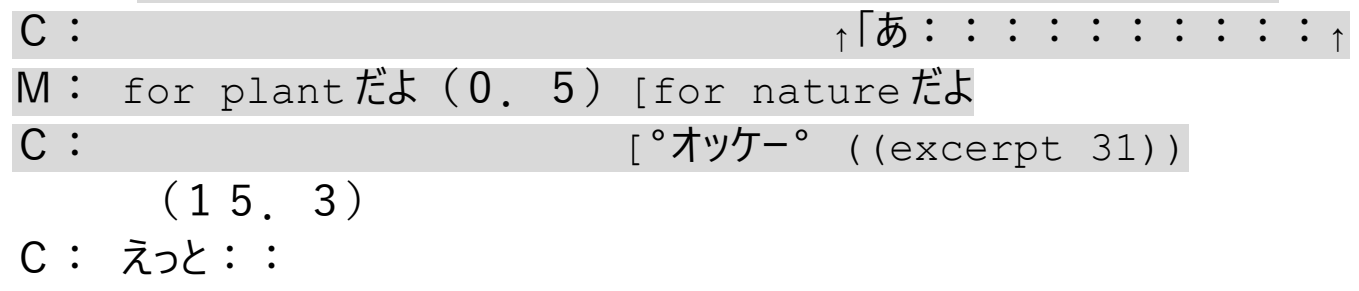

C : ${ }^{\circ}$ rainwater to: : ; （4，2） あっと何だっけ？植物にあげられ る? ${ }^{\circ}$

$M ：$ うんん゚うん とか（0，3）とか（1，0）や：：まだ他にもいいのが あれば全然（．）いいんだけど

(0.9)

C : いえ（0．4）まじこれに関しては何も言う「゚ことはない゚

M : 「「ふふなっはっはっ@

$$
\text { (1. 2) }
$$

$M:$ yep

$$
\text { (5.5) }
$$

M： えつじやあ もう ここノート出た：：？

$$
\text { (1.5) }
$$

$C:$ jh

$M ：$ あっもう出てんだ早いな

$$
\text { (0.2) }
$$

C: to:::::::: ${ }^{\circ}$ 何 ${ }^{\circ}$ give?

(1.6) 


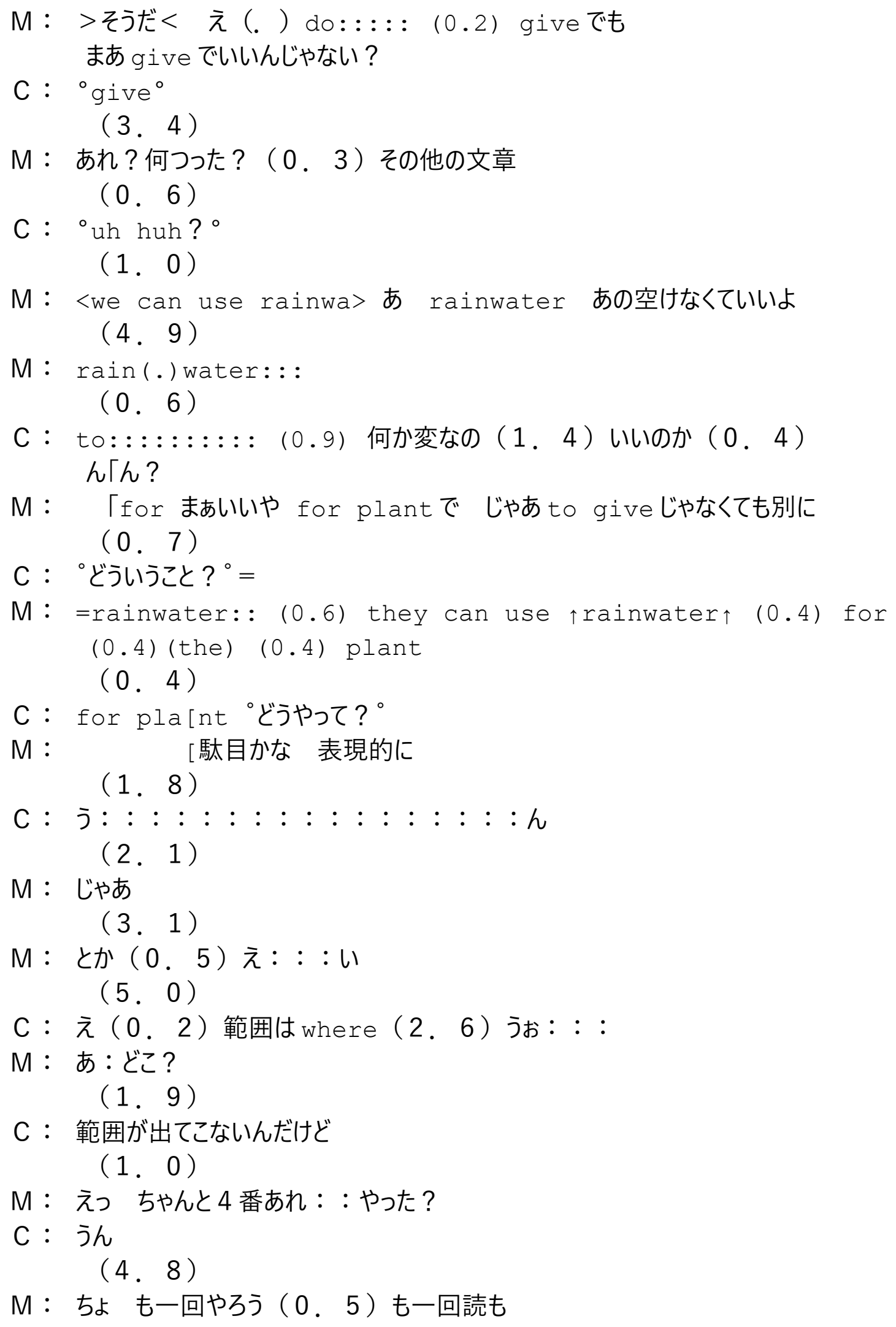




\section{(2.4)}

$\mathrm{M}$ ：あつ読めない

(5.4)

$M ：$ 文字の方 文字の方

(2. 2)

C : $\quad($

(2. 4)

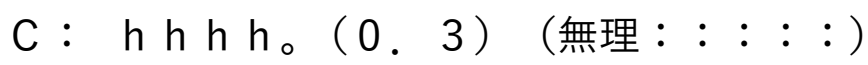

(2. 6)

M：あ出た出たよ：（．）あ出たよ（1，6）俺らのノート本当にある？

(2.5)

M： we can use rainで合っ（）てる？（0４）違う

(3.5)

C : ${ }^{\circ}$ なん`か (.) さ: : : :

(1.4)

$\mathrm{M}$ ：あれ？（1，2）俺らのは？

(3.1)

$\mathrm{M}$ ： 俺らのは?

(2. 0$)$

$\mathrm{M}$ ： 俺らのは?

(1.9)

$C:{ }^{\circ}::: h^{\circ}$

(4.0)

$M ：$ あった：：めつちゃずれてるよ場所

(0.3)

C: sorry: : : $(0.4)$ eha ha ha hal

$\mathrm{M}: \mathrm{C}:::::$ : $\ulcorner:::::::::$ :

C: 「@ha:: ha: ::::::::@ (.) sorry

$\mathrm{M}$ ：雑なってるよ：：：：

C : 。ごめんなさい

(5.3)

$\mathrm{M}$ ：まあい： : : : ?

(1.5)

C：（違うんだっけ?／次何だっけ?）

(0.9)

M： urban plazaで？（0．5）フィニッシュじやね多分？（1，0）あ：

:まだ だ

(1.6) 
$M ： 5$ 番俺らさっきやった記憶ない？

$M ：$ えっ やったっ「け？゚ややたか：：

C：「やった やった やった：やった：

(3. 5 )

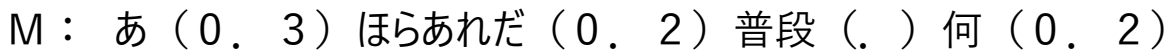
学校行くとき何使ってる?「だ

C :

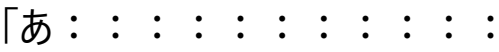

(1. 8)

M : easy one (だ/で) easy one

(9.2)

M： え じやあさっき@と。同じでいい？@ここも=

C : =いいよ : :

(3. 2)

C：さっきもしかしたらさあ

$M:$ : : : h?

(0.4)

C：日本語打てば良かった；

(2.4)

C：まあみんなは英語だったけど

(0.3)

$\mathrm{M}:$ ふふ: : : ん?

(1.0)

C：そ：：思うんだけど気のせい？

( 15.1 )

C:ふ:: : : h (0.2) fini::::::sh

(1. 0$)$

M: fini::::::sh

?: fini::sh

M: ahu hu hue

?: ( )

M : ye: : :ah

?: yeah

(0.7)

M : efinishe=

S: =you're done?

M : yeah [ :

S: [great

?: okay? 
( 9.0$)$

S: are you (0.2) finished?

( 0.4 )

$\mathrm{M}: \quad[$ yeah

C : [yeah

[JAPESLSep072016RC2.1]

Group 2 finds and finishes location 1 and starts working on location 2.

((transcription starts at $0: 58)$ )

$0 ?:$ え

$(0.3)$

Y ? : you are not good at the map

$(0,2)$

?: ${ }^{\circ}(\text { really? })^{\circ}$

?: ${ }^{\circ}$ huh huh huh ${ }^{\circ}$

(0.9)

$0: Y$ is fool

( 0.3 )

Y?: ${ }^{\circ}$ huh huh [hah hah hah ${ }^{\circ}$

$\mathrm{K}$ ? :

(3. 3 )

S ： 0っち俺たくさん撮つとくよこの@動画で@

( 0.3 )

0 ? : hah .hh

(0.5)

$\mathrm{K} ：$ え 何でそ己 (チーム) そうなるの？

(0.2)

S： 分かんねえ@何か@

$\mathrm{Y}$ : hah

$(0.5)$

$0:$ oh: :

$(0.2)$

Y: (ma[ny $\left[: \quad{ }^{\circ} \mathrm{su}^{\circ}{ }^{\circ}\right)$

$0: \quad[$ no

S ? : > ${ }^{\circ}$ 後ろから[カメラ付いてくる（んだけど） ${ }^{\circ}<$

O : [oh: : : I'm sorry

(1. 1) 


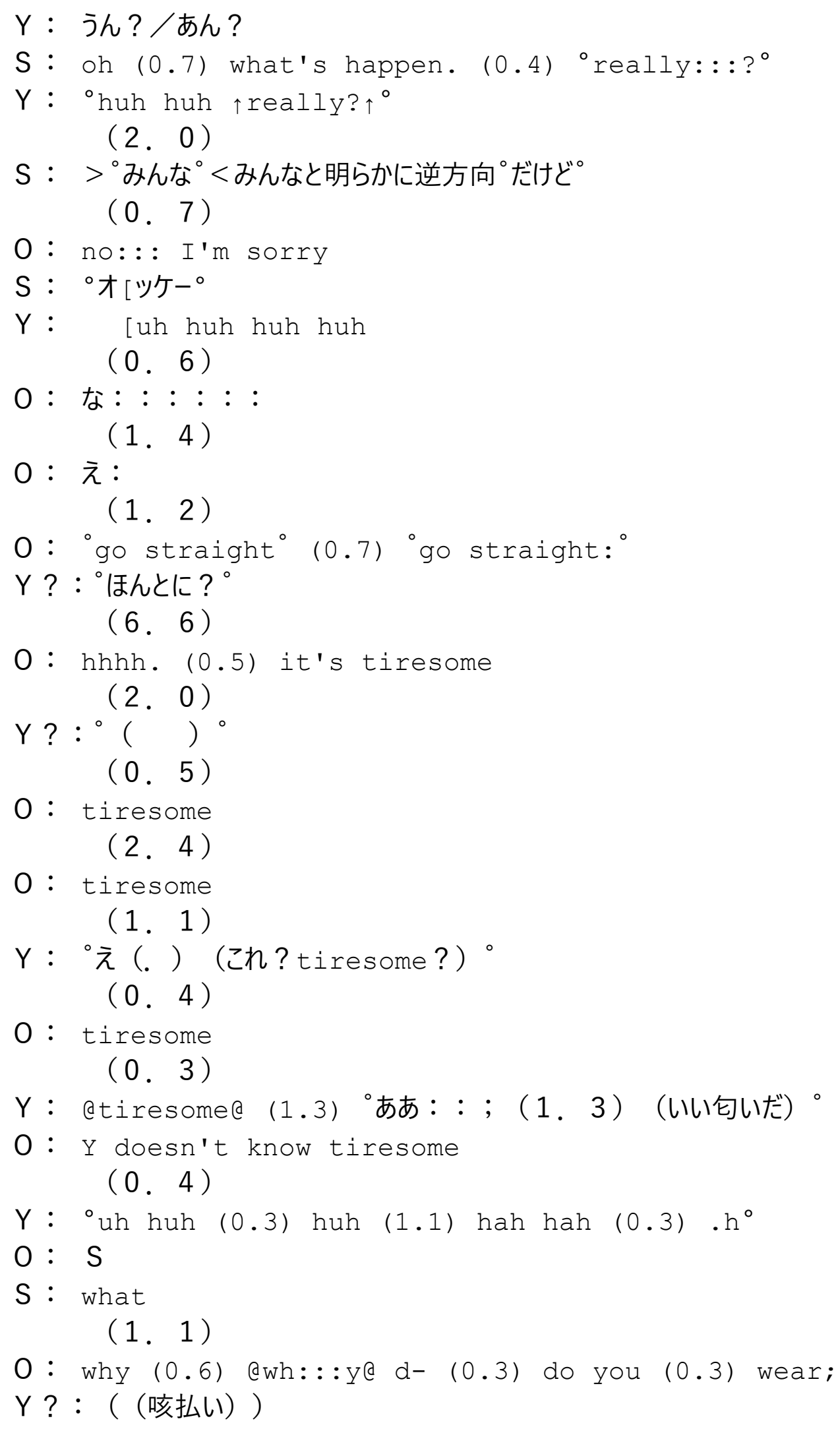


(0. 2)

0 : such a camera?

(1. 2)

$S:{ }^{\circ} I$ don't know ${ }^{\circ}$

Y ? : ( )

S: ${ }^{\circ}$ why why onlly $(\text { and me })^{\circ}$

O : [okay view

(1.5)

S: what's

O：あれ（０．３）あれ嘘また同じところだごめん゚（1１１）うるせえな こいつ

$Y: \quad(\Gamma)$

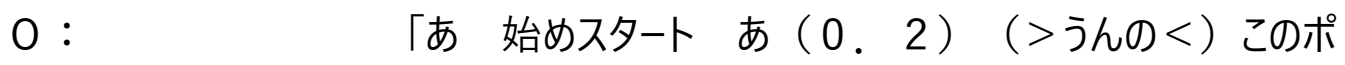
イントでいいのか

(3.1)

0：。つつ゚転んじやうよこんな歩き何とかしてたら

(1.3)

$\mathrm{S}:{ }^{\circ}(\text { でも })^{\circ}(0.9)^{\circ}>$ 俺なんて動画撮りながら歩いてるく

(1. 0$)$

$0:{ }^{\circ}>$ 恥ずかしいな：ちょつとお前ら（なんちやって）<゚（，2）

huh .heh

( 0.6 )

$Y:{ }^{\circ}$ 絶対私恥ずかいいこれ

O：ちょつと離れて歩こう@か@

Y: eh heh heh heh (0.5) .hhhhhhh (0.2) (

( 0.3$)$

0 ：あれ：;ちょっと待って

(0.4)

S : ‘めวちゃこれ $(\quad)$ 。

O : これどこ向かってん「のこれ

S：「「iPad 持って歩くよりは：付けた方がいいかなと

思ったけど：：：

O：（これ何）「どこ向かってんの

S：（「気が付いたこと）と言えばめっちゃ恥ずかしいのとあと後ろから人 「が（0，3）と

0 : 「あ

(0.6)

$Y:$ yeah $[a h$ 


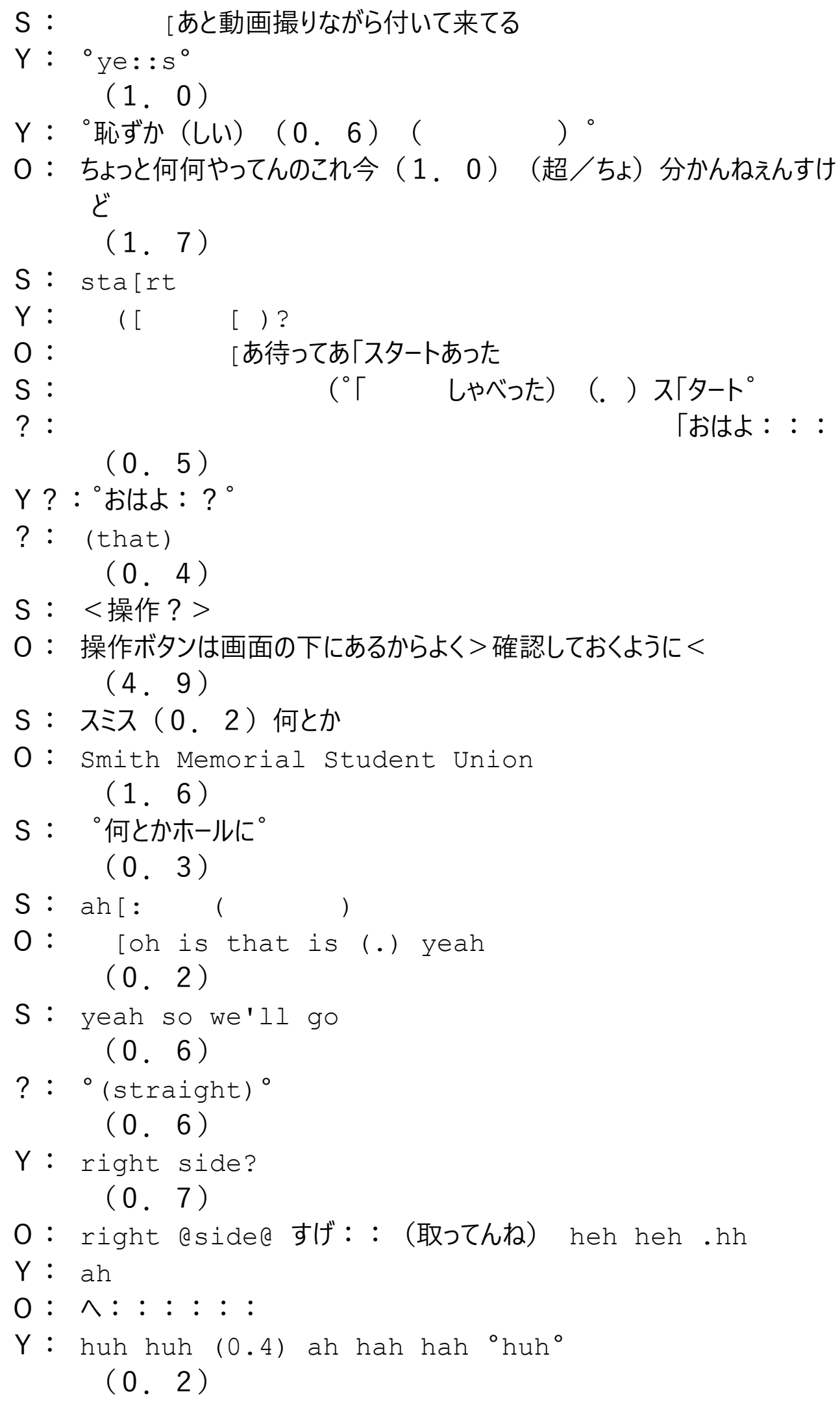




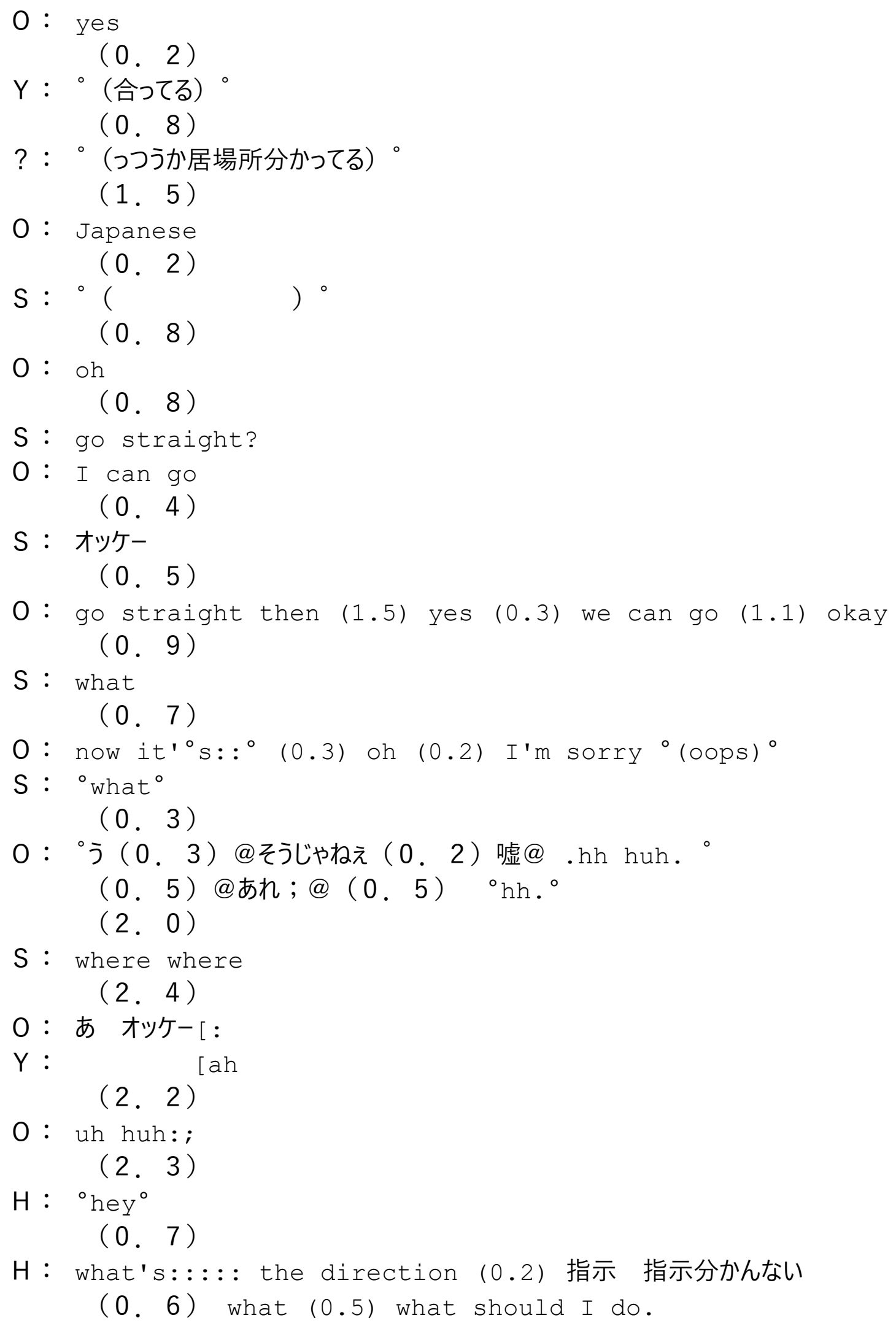


(0.6)

S：＞自転車「置き場に（関するところ）<自転車置き場ど「こ（）

o : 「(何) I don't know

$\mathrm{H}$ :

S : >そこだよく（（指差す））

(1. 4 )

?: ${ }^{\circ} \cdot h^{\circ}$

(1. 1)

$\mathrm{H}:{ }^{\circ}$ eh what sh[ould you do ${ }^{\circ}$

S: $\quad[$ ah view?

0 : やビューできた :

$S:$ 来た 来た

(2. 0$)$

O ：PSU のキャンパスには 25 か所もの自転車置き場がある（0，2）通学に 自転車 $(0.2)$ つつ 何：

S : 何 $=$

O : = 敵 :

$\mathrm{H}:$ だ :

S：だ：な「に（）

$\mathrm{H}: \quad>\Gamma$ (違うcan) I [I can't see that

0 :

( 0.3$)$ [eh. .he

O：通学に自転車を使うこと゚の゚>メリットデメリットは何だろうか君達の 答えをノート欄にく

(2.7)

$\mathrm{H}$ ：あ：（0，5） オッケー

(2.3)

$\mathrm{S}$ ：あ(. ) 待って : 録- (0，9) 録音や;

( 0.2$)$

$\mathrm{H}:$ え: [so::: (0.2) so: must

$S: \quad{ }^{\circ}$ 録画 $^{\circ}$

(2. 8)

$\mathrm{R}:{ }^{\circ}$ ほつやん

(0.6)

$\mathrm{H}$ ：通学に使う>ことの゚メリット $\left(\right.$ 「だって） ${ }^{\circ}<$

O :

「huh [.hhhh

$\mathrm{R}$ :

○[オッケー。

$(0.5)$ 


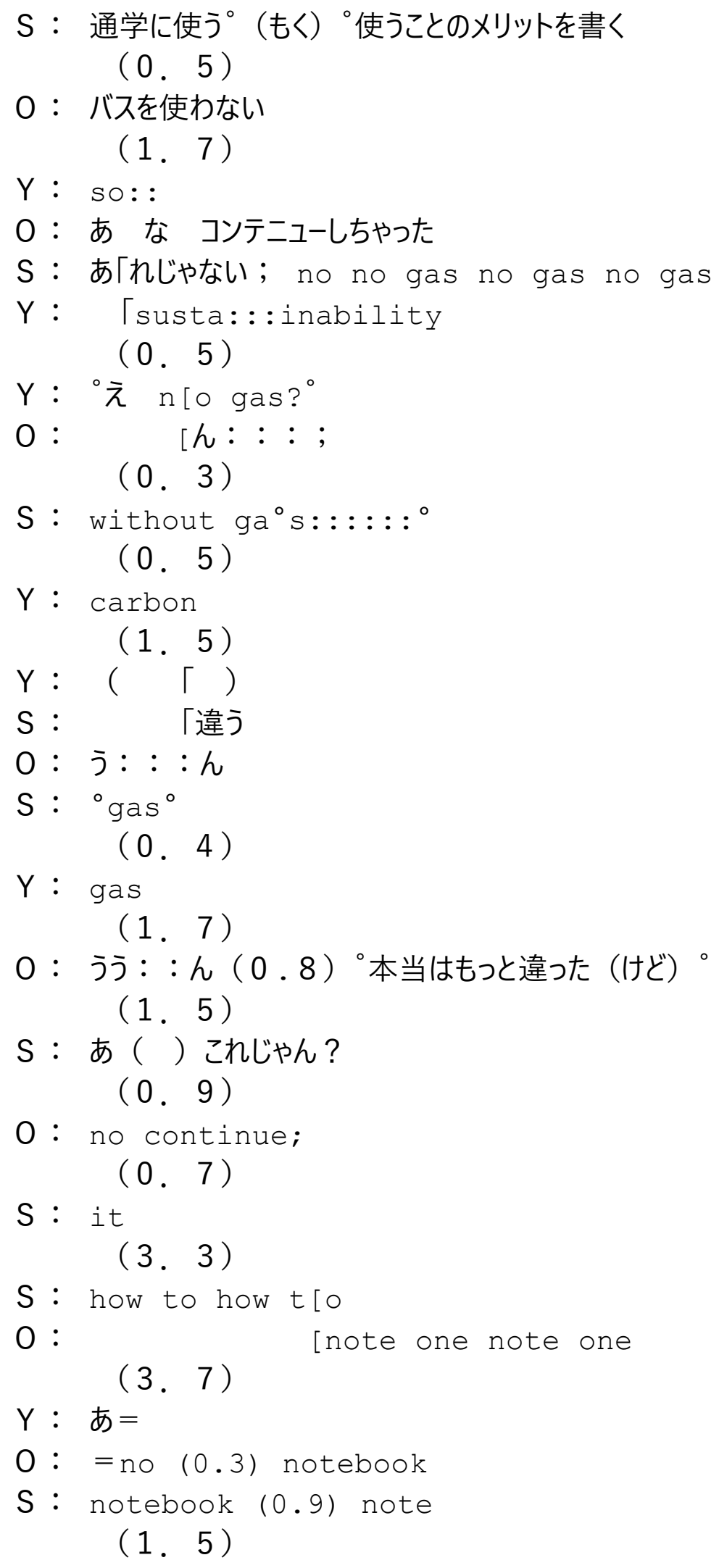




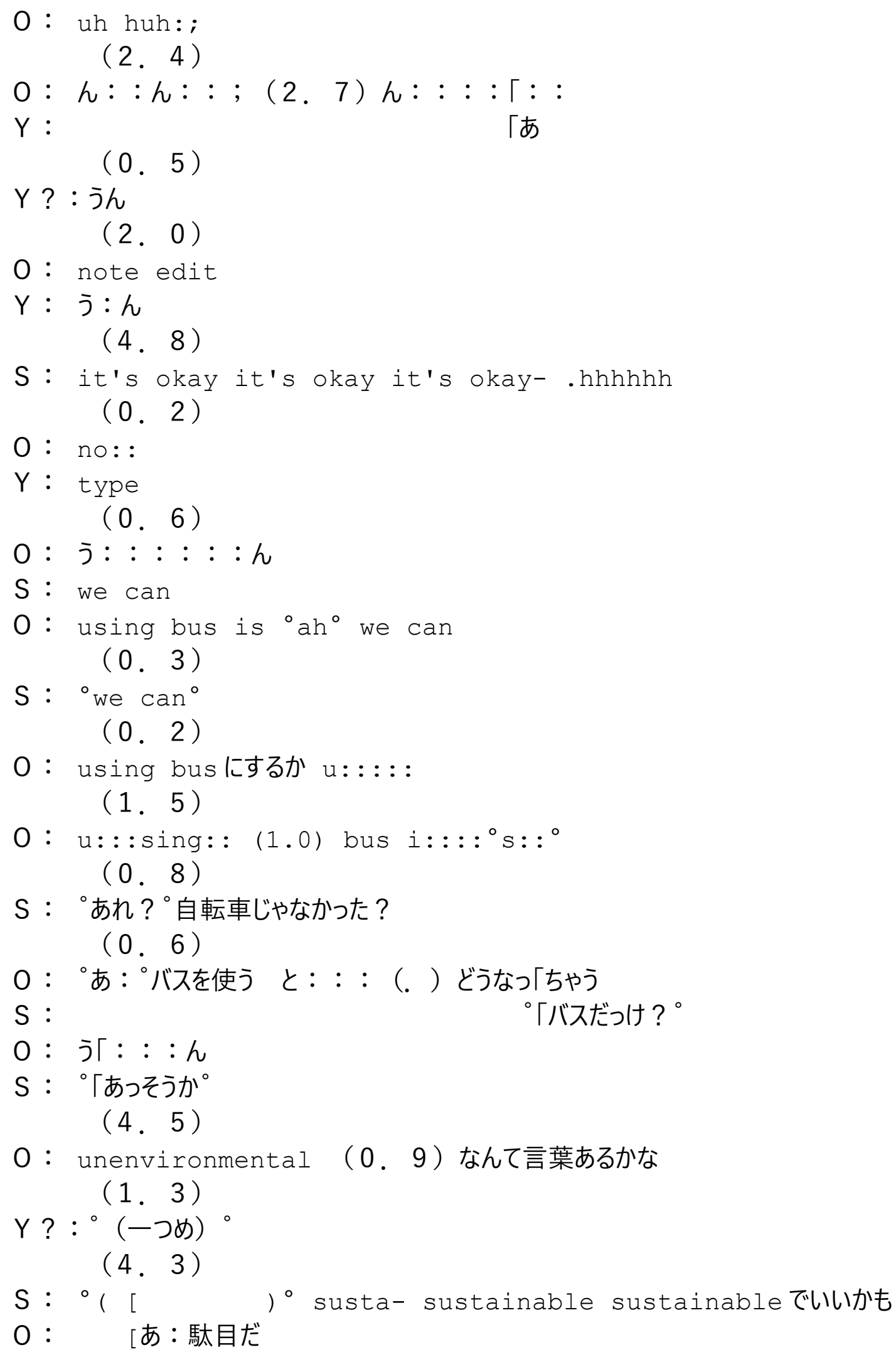




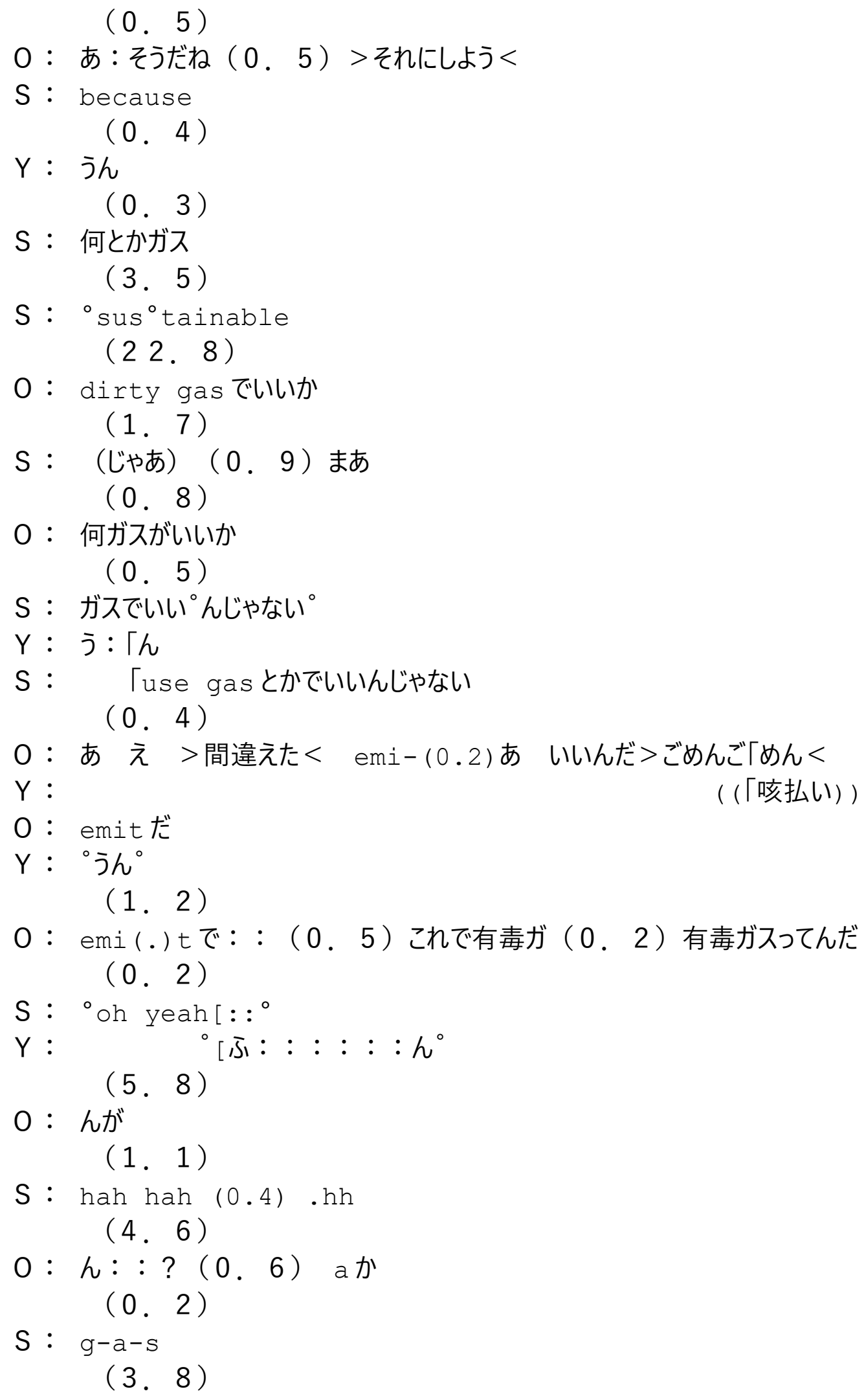


S: so:

(0.9)

O : あ : ごめん

$(0.7)$

S？：あ：いいや

(3.3)

S: we (1.0) can use (0.8) bicycle

(2. 9)

$S$ : rather than bus

(0.3)

$0:$ : : biked

( 0.7 )

S: more clean than (0.4) bus

(0. 2)

0 : my

( 10.5$)$

0 : んん?こんなんでいいか : ?

( 0.7 )

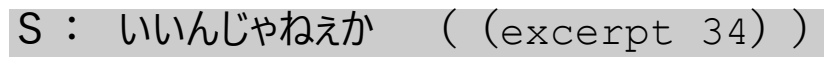

(0.2)

S : オッケー

0 : using busses is not sustainable because these en emit toxic gas (.) so we can use (0.8) bi- bikes for environment

S : オッケー

0 : ${ }^{\circ}$ vironmen ${ }^{\circ}$

(1.7)

0 : オッケー;

(0.8)

Y : オッケー:

S: save

(5.0)

S : >オッケー<

$(0.6)$

S : >゚あっそうか（これ note）じやね ? ${ }^{\circ}<$

(3.2)

$\mathrm{S}$ ：ノートワンじや「ねえか

Y : （「ブルーチーム） 


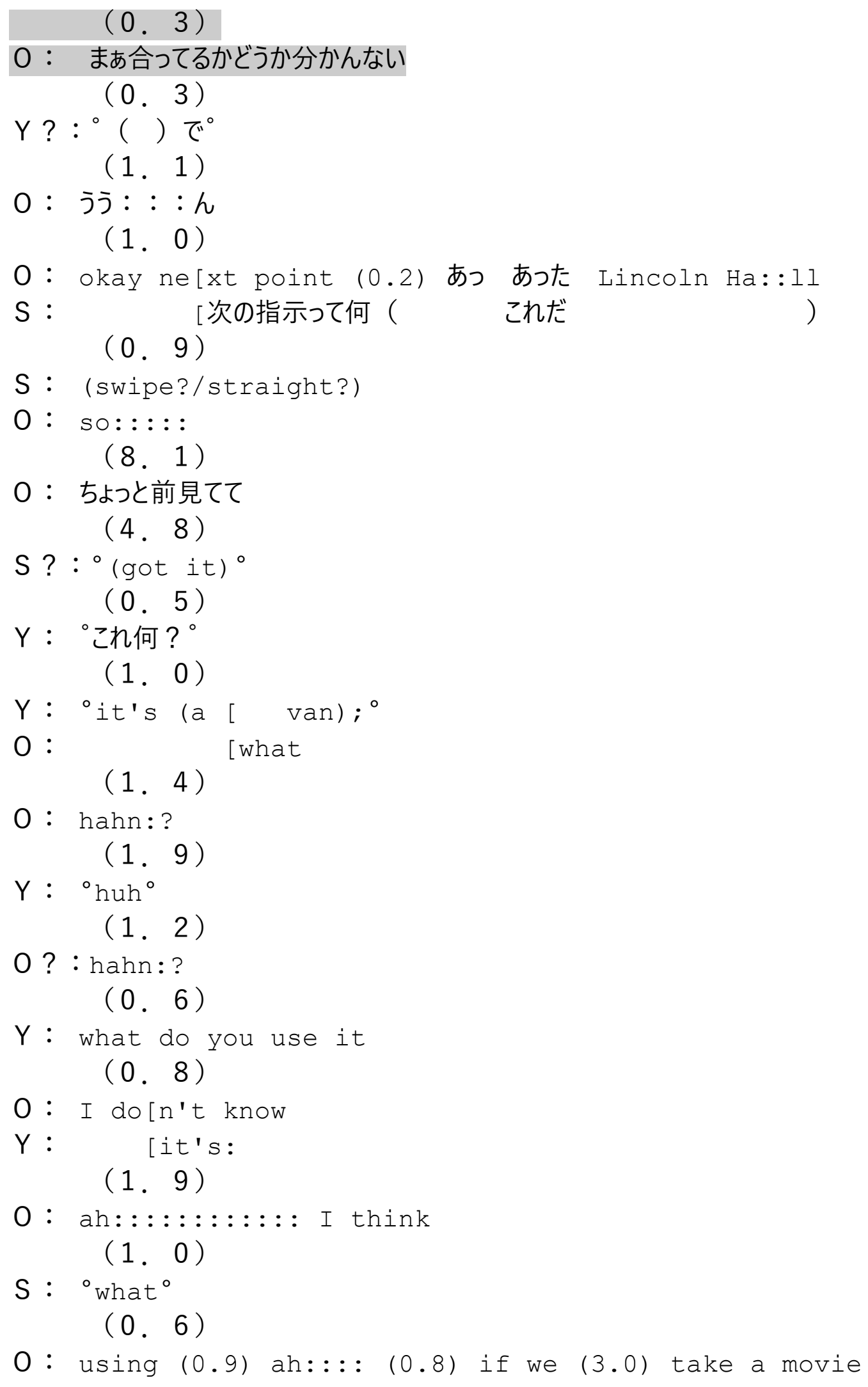




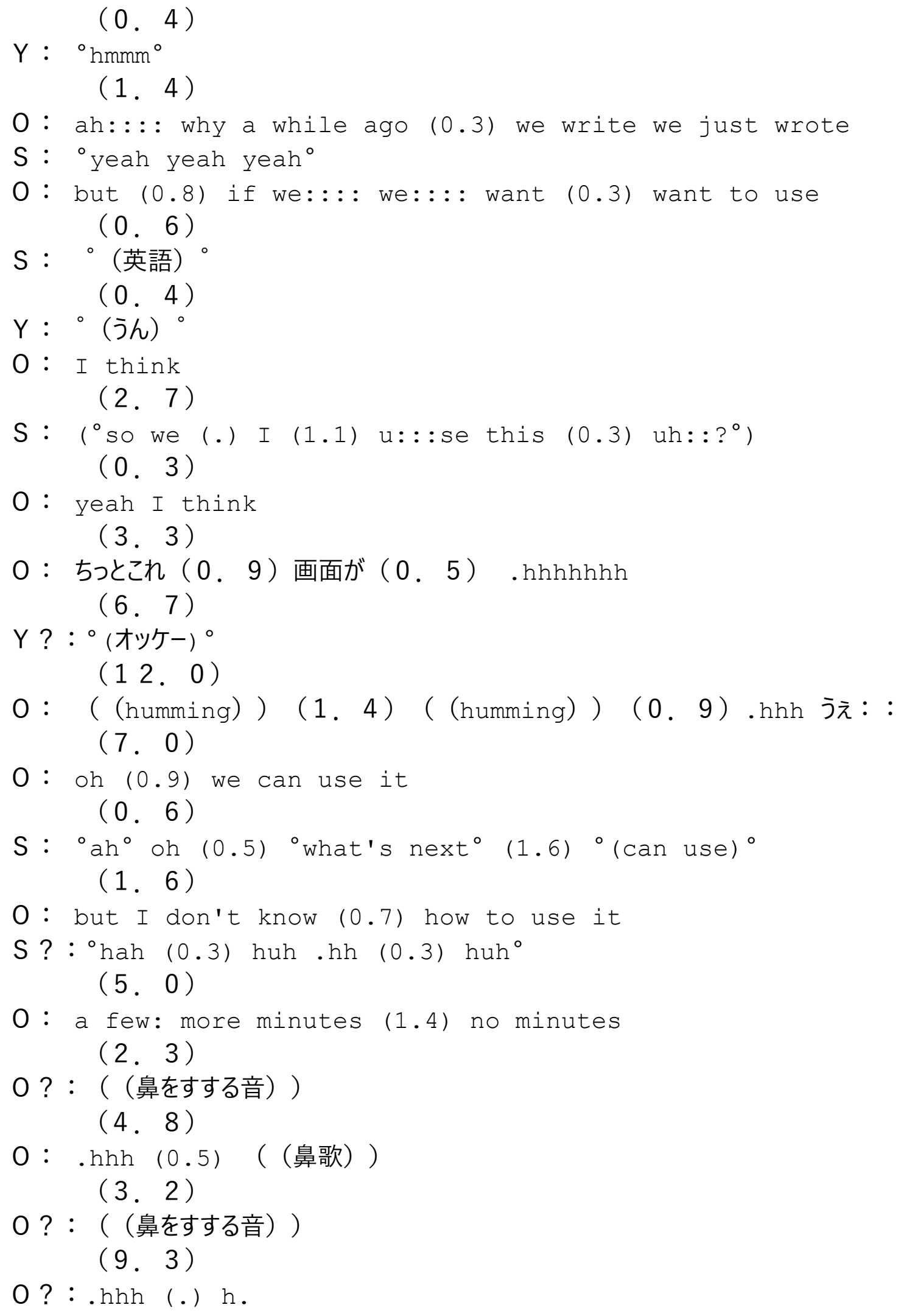


(5. 4)

$0:$ yes

( 1.0$)$

S?: ${ }^{\circ}$ yeah $^{\circ}$

O : okay (1.6) go at corner

(2. 3 )

$0:$ oh

$(0.5)$

S : oh

(0.8)

O ：リンカンホールの屋根に取り付いているソーラーパネルからビルのエネル ギーの約 3 パー セントが供給されている 「ソーラーパネルを使う=

S ?:

$\circ \Gamma^{\circ}{ }^{\circ}$

O : =ことのメリット・デメリットは何だろうか君達の答えをノート欄に（ツールを使って）タイトル はノートに ( )

$Y$ : huh $(0.3)$ huh

(2. 7 )

$\mathrm{S} ：$ あ (. ) ソーラーパネルができるまで?

S ? : ${ }^{\circ}($

(2. 6)

(0. 2)

0 : > 何笑ってんの<

(0.8)

0 ：あ ちょっと濡れちやってるよ

(2. 4)

S ? : ${ }^{\circ}($

(4.4)

こんなふうに ）。

O : まあいいっか hih hih hih

Y: huh huh [uh huh huh

O : [hih hih hih hih .hih: hih. ${ }^{\circ}$ (jける) ${ }^{\circ}$.hhh okay

S: $\left(^{\circ} \quad[\quad)^{\circ}\right.$

O : [あ: : : : : : : ${ }^{\circ}$ ん: : : : : : : : ${ }^{\circ}$

S: $\left[{ }^{\circ}()^{\circ}\right.$

O: [the good point $(0.7)$ to use solar panel is (1.0) what do you think

( 0.7 )

S: yeah-

$Y:$ ah $(0.3)$ a- 
[JAPESLSep072016HC1,4]

Group 3 finishes the location 1 prompt and heads to location 2.

$\mathrm{H}:$ う/あ : : : : : ん

$\mathrm{R}:$ (choose)

$\mathrm{H}$ ： あれだよ

（1．4）（（Hは2 回手を叨く））

A : sus-

$\mathrm{H}$ : environment

A : sustaina-

$\mathrm{H}:$ env[ironment

A : $\quad$ sustainable

R : we: : ::::: do: :::n't

(1. 8)

$\mathrm{H}$ : use a gas (0.4) gasoline?

(0.7)

$\mathrm{R}: \quad(\quad[\quad)$

A : [don't use carとかでいいんじゃない ?

(0.7)

R : mo:::re:: : : footprint

$(0.4)$

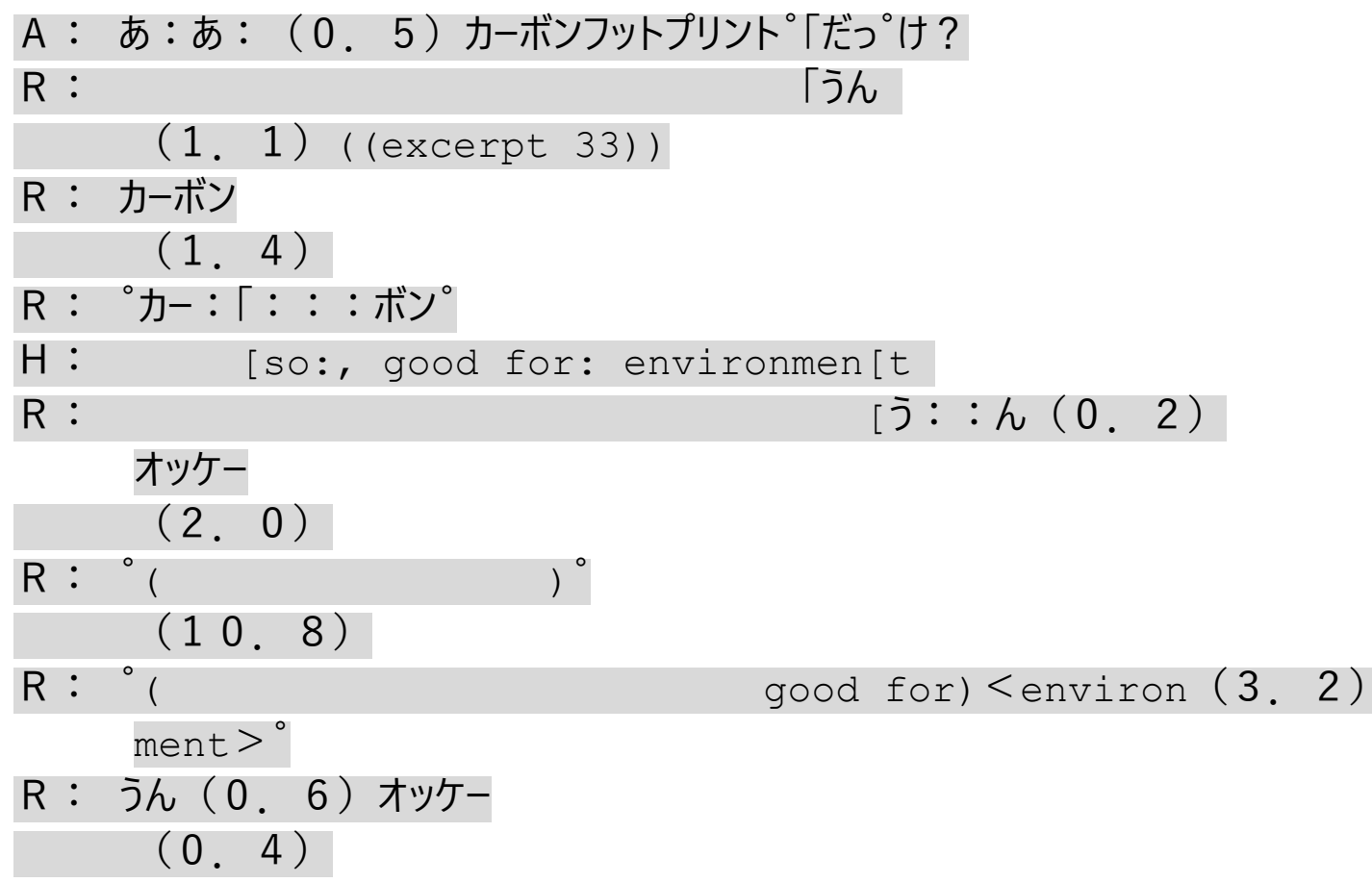


$\mathrm{H}$ : ${ }^{\circ}$ オッケー゚

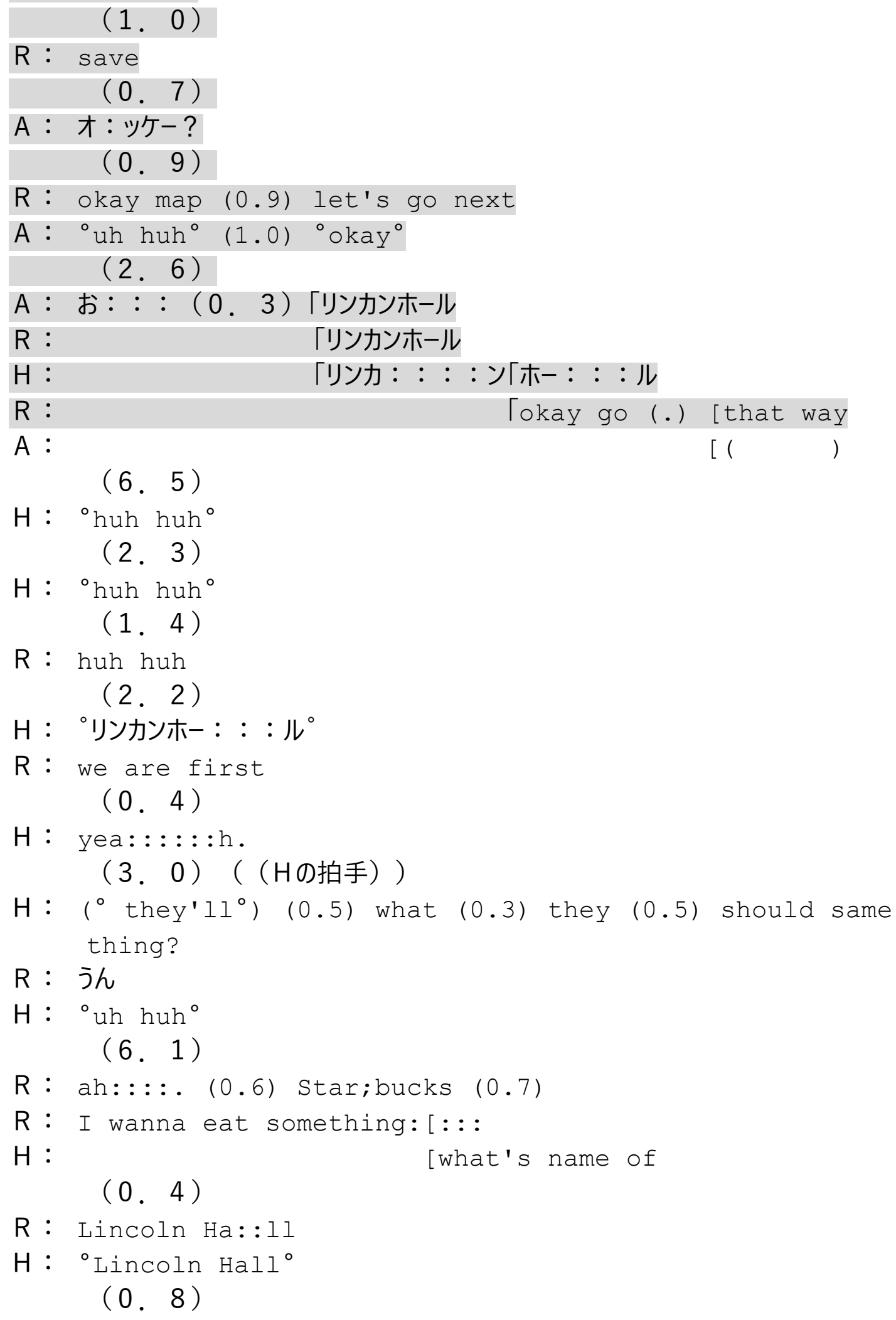




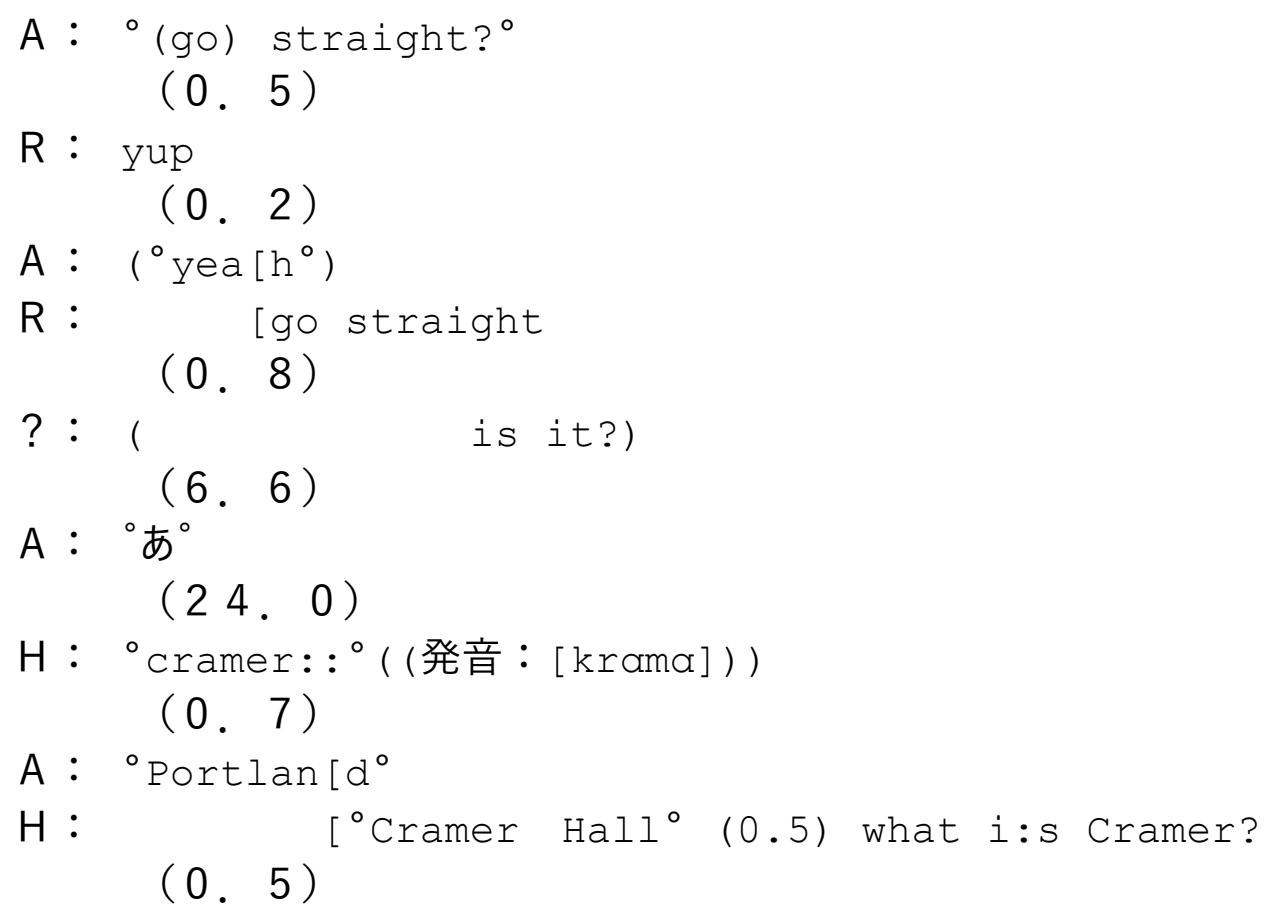

A : Crame $[r$

R: $\quad$ [Cramer (1.0) I don't know

(0.9)

A : ${ }^{\circ}$ Cramer (か) ${ }^{\circ}$

(1.0)

$\mathrm{R}:$ (is this) [name?

$\mathrm{H}: \quad\left[{ }^{\circ}\right.$ (Cra) mer ${ }^{\circ}$

(0.8)

$\mathrm{H}:{ }^{\circ}$ na: : : me? ${ }^{\circ}$

A: human's name ah (0.4) person's name

$$
\text { (0.5) }
$$

R : hmm:: (.) I think so

(1. 8)

A： ${ }^{\circ}$ Cramer i::s (0.6) （>何だっけ<何だっけ?）（0.6） コンポーザーの?。

(2. 0 )

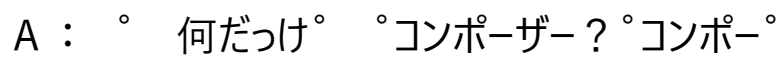

$\mathrm{H} ：{ }^{\circ}$ コンポーズ? ${ }^{\circ}>$ あ：：あ：あ<

$\mathrm{R}$ ：何？（．）コンポー ズ

$\mathrm{H}$ ：コンポーズ（。）構成：：：する（。）>何か：：<（0，3)

○作った人でしょ? $<$ 。

( 0.3$)$ 


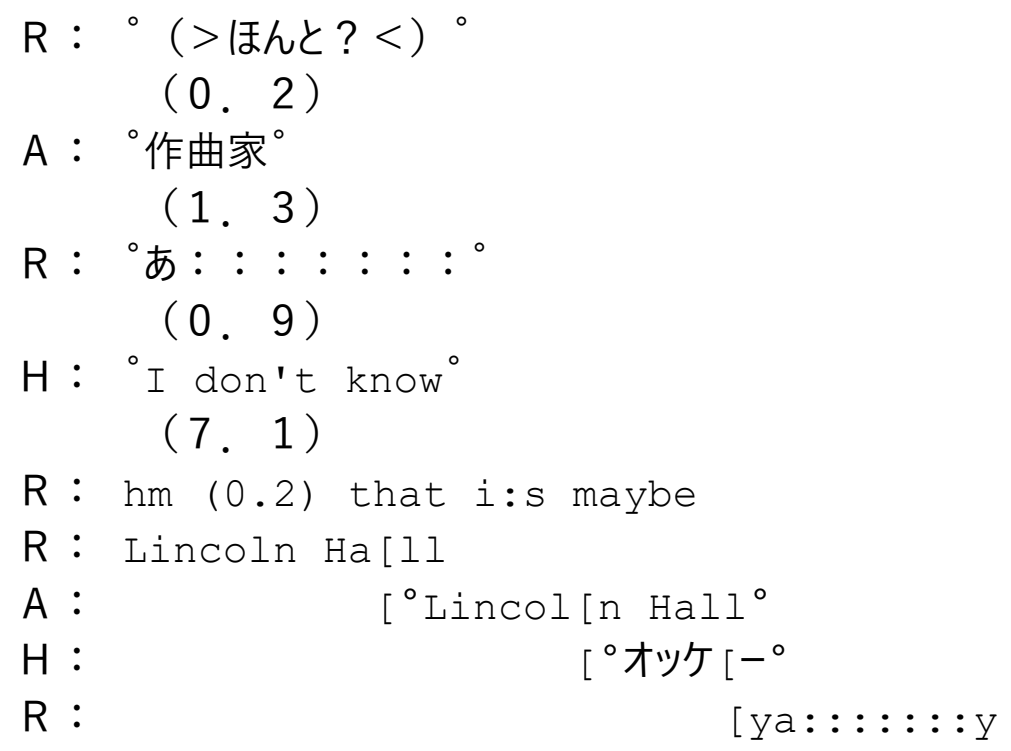

